\title{
Basic limnology of 30 continental waterbodies of the Transmexican Volcanic Belt across climatic and environmental gradients
}

\author{
Itzel Sigala, Margarita Caballero, Alexander Correa-Metrio, Socorro Lozano-García, \\ Gabriela Vázquez, Liseth Pérez, Edyta Zawisza
}

Itzel Sigala

Posgrado en Ciencias Biológicas, Instituto de Geología, Universidad Nacional Autónoma de México, Ciudad Universitaria, 04510, Ciudad de México, México.

\section{Margarita Caballero}

maga@geofisica.unam.mx

Instituto de Geofisica, Universidad Nacional Autónoma de México, Ciudad Universitaria, 04510, Ciudad de México, México.

\section{Alexander Correa-Metrio \\ Socorro Lozano-García \\ Liseth Pérez}

Instituto de Geología, Universidad Nacional Autónoma de México, Ciudad Universitaria, 04510, Ciudad de México, México.

\section{Gabriela Vázquez}

Instituto de Ecología, A.C. Carretera antigua a Coatepec 351, El Haya, Xalapa 91070, Veracruz, México.

\section{Edyta Zawisza}

Institute of Geological Sciences, Polish Academy of Sciences, Research Centre in Warsaw Twarda 51/55, PL00818 Warsaw, Poland.
BOL. SOC. GEOL. MEX. 2017

VOL. 69 NO. 2

P. $313-370$

\section{ABSTRACT}

Thirty waterbodies on the Transmexican Volcanic Belt were studied using standardized methods, covering an altitudinal gradient from 737 to 4283 masl and different climatic types. Waterbodies of tree different origins were included: tectonic $(4)$, volcanic $(11$ craters or maars and 7 volcanic dams) and reservoir (8). Reservoirs and tectonic lakes were mostly shallow $(<6 \mathrm{~m})$ while volcanic lakes were the deepest $(>25 \mathrm{~m})$. Most were freshwater bodies with alkaline waters $(\mathrm{pH}>7.5)$ dominated by $\left[\mathrm{Ca}^{2+}\right]$ or $\left[\mathrm{Na}^{+}\right]$and $\left[\mathrm{HCO}^{-}\right]$. Subsaline $(6$ and hyposaline (2) lakes were dominated by $\left[\mathrm{Cl}^{-}\right]$- $\left[\mathrm{HCO}_{3}^{-}\right]$and $\left[\mathrm{Na}^{+}\right]$. In thirteen lakes, nutrient levels could be limiting primary productivity, mostly $\mathrm{P}$, but also $\mathrm{N}$ and $\mathrm{Si}$. Half of the lakes (16) were eutrophic or hypertrophic and most of these were also shallow $<8 \mathrm{~m}$ and correlated with warm, moist conditions. Ninety-seven taxa of aquatic organisms (phytoplankton, and surface sediment diatoms, testate amoebae, cladoceran and ostracodes were reported, which could potentially be used as bioindicators. Principal component analysis (PCA) showed that temperature and precipitation were the main environmental gradients related to the lakes' limnological characteristics: colder climates related with lowest TDS $(<100$ $\mathrm{mg} / \mathrm{L}$ ); dry climates with subsaline and hyposaline lakes, and warm-moist climates with eutrophic and hypertrophic lakes. Through the Procrustes technique we obtained indications that general geographic variables were important for some of the lakes, whereas the loca factors were significant for others. It is through the knowledge of the basic limnology and biodiversity of Mexican lakes that more complex or detailed studies can be proposed leading to a better understanding, management, and conservation of water resources.

Keywords: Hydrochemistry, salinity, trophic state, benthos, plankton.

\section{RESUMEN}

Empleando metodologías estandarizadas se estudiaron 30 cuerpos de agua en la Faja Volcánica Transmexicana a lo largo de un gradiente altitudinal (737 a 4283 msnm) y climatológico. Los lagos se incluyen en tres categorias: tectónicos (4), volcánicos (11 cráteres o maars, 7 represas volcánicas) y presas (8). Los cuerpos más someros $(<6 \mathrm{~m})$ fueron principalmente presas y lagos tectónicos y los más profundos (>25 m) volcánicos. La mayoría fueron lagos de agua dulce y alcalina $(p H$ $>$ 7.5) dominados por $\left[\mathrm{Ca}^{2+}\right]$ o $\left[\mathrm{Na}^{+}\right]$y $\left[\mathrm{HCO}_{3}^{-}\right]$. Los lagos subsalinos (6) e hiposalinos (2) estuvieron dominados por $[\mathrm{Cl}]-\left[\mathrm{HCO}_{3}^{-}\right]$y $\left[\mathrm{Na}^{+}\right]$. En trece lagos los niveles de nutrientes pudieron ser limitantes de la productividad primaria, principalmente el $P$, pero también $\mathcal{N}$ y Si. La mitad (16) fueron lagos eutróficos o hipertróficos y estos fueron predominantemente someros $(<8 \mathrm{~m})$ y correlacionaron con climas cálido-húmedos. Se reportaron 97 taxa acuáticos (fitoplancton y diatomeas, amebas testadas, cladoceros y ostrácodos en sedimento superficial) que potencialmente pudieran ser usados como bioindicadores. Un análisis de componentes principales (PCA) demuestra que la temperatura y precipitación fueron los gradientes ambientales más importantes ligados con las características limnológicas: climas relativamente fríos correlacionaron con los lagos más diluidos (TDS < $100 \mathrm{mg} / \mathrm{L})$; climas secos con los subsalinos e hiposalinos y climas cálido-húmedos con los eutróficos e hipertróficos. Un análisis de Procrustes indica que para algunos lagos los factores geográficos generales fueron más importantes mientras para otros los factores locales fueron determinantes. El estudio y conocimiento de la limnología y biodiversidad de los lagos mexicanos permitirán plantear estudios más detallados y / complejos que lleven a mejores estrategias de conservación y manejo de los recursos acuáticos.

Palabras clave: hidroquímica, salinidad, estado trófico, bentos, plancton. 


\section{Introduction}

Central Mexico is characterized by the presence of a volcanic chain that crosses the country from $\mathrm{E}$ to $\mathrm{W}$ at around $18^{\circ}$ to $22^{\circ} \mathrm{N}$. This volcanic chain is known as the Trans-Mexican Volcanic Belt (TMVB) and is the largest Neogene volcanic arc of North America, with a length of $1000 \mathrm{~km}$ and an area of $160000 \mathrm{~km}^{2}$ (Ferrari et al., 2012). Along this wide surface, topographic heterogeneity favors the presence of several lacustrine basins across a broad range of climatic conditions which are determined mostly by the significant altitudinal gradient (the highest peaks reach $>5000$ masl). Besides temperature, this topographic gradient is also associated with differences in precipitation and/or evaporation, with generally drier climates on the western, lower altitude basins; but the driest region, under a rain shadow effect, is on the easternmost high-altitude basin (Oriental).

Throughout the history of the region the lakes along the TMVB have been core areas for cultural development (Faugère-Kalfon, 1996; Niederberger, 1979; Serra-Puche, 1988) as they are favorable locations for agriculture, fishing, hunting, and recreational activities. Thus, human impact around these lakes has also a long history, which in modern times has been sharpened by stressors such as global warming, urban development and widespread changes in land use (Alcocer and Bernal-Brooks, 2010).

Lakes are sensitive ecosystems to changes in their environment (Adrian et al., 2009) and we know that in several of these lakes the impact of modern stressors has already caused, for example, important reductions in lake levels or increases in turbidity and trophic status (Alcocer et al., 2000a; Caballero et al., 2006; Kienel et al., 2009; Komárková and Tavera, 2003). These changes can generate social and economic problems as well as a significant reduction in the biodiversity of these ecosystems, so it is important to have basic limnological information that allows a better understanding of these aquatic systems as a basis for further ecological studies, and also for the management and restoration of the water resources they represent. In some of these lakes the changes have been very quick, but the rate of change is difficult to evaluate as there are relatively few limnological studies undertaken in the area to allow understanding the degree and speed of such transitions. Limnological information about these lakes is therefore relevant to document their current status, which is necessary as a reference when evaluating past conditions. In the same way, it is important to identify the organisms that live in these waterbodies, especially those that can be used as bioindicators in modern and paleo-environmental research given their high potential of preservation in the sediments. Phytoplankton is probably the most sensitive but also the remains of diatoms, testate amoebae, cladocerans and ostracodes preserved in sediments can be very useful to determine the conditions of the water body in which they lived. All these groups have short life cycles, so they quickly respond to environmental changes, enabling to understand the present conditions of the lacustrine ecosystem and open the possibility of evaluating recent changes through paleolimnological methods by, for example, comparing the bioindicators contents in modern and pre-human impact sediment samples.

Previous limnological studies in the TMBV region have focused on a few of its lakes, mainly the largest and/or deepest (e.g. Alchichica: Alcocer et al., 2000b; Kaźmierczak et al., 201 1, Chapala: Hansen and van Afferden, 2001; Quiroz et al., 2008, Pátzcuaro: Alcocer and Bernal-Brooks, 2002; Bischoff et al., 2004, Zirahuén: Chacon-Torres and Rosas-Monge, 1998; Bernal-Brooks and MacCrimmon, 2000a). Scarce limnological information is available for most of the smaller waterbodies, but even for the best characterized lakes, results are often difficult to compare, as studies are carried out following different methodologies and/or only report results on specific physico-chemical characteristics or biological groups. Only a handful of studies have been performed simultaneously in more than one lake to allow for regional comparisons (e.g. Armienta et al., 2008; Davies et al., 2002). 
The aims of this study are, therefore (1) to describe the main morphometric and limnological characteristics of 30 waterbodies on the TMVB in central Mexico using standardized analytical methods so that the data are easily comparable, (2) to provide information about their current nutrient levels and trophic state, (3) to report the dominant aquatic bioindicator taxa (phytoplankton and sedimentary diatoms, testate amoebae, cladocerans and ostracodes) present at each site as a contribution to future ecological and paleoecological research, (4) to assess the influence of climate and geographic location over the limnological variables of these waterbodies.

\section{Materials and methods}

Thirty waterbodies located along the TMVB (Figure 1) were sampled once from late summer to early autumn (lakes El Sol and La Luna in August 2010 and the rest of the lakes between June and October 2011). The geographical location (latitude, longitude, altitude) of each site was taken using a handheld navigator (GARMIN GPSMAP 62 stc) and confirmed in Google Earth ${ }^{\circledR}$. All of them were studied following uniform methodologies for field work, laboratory analyses and taxonomic determinations of bioindicators (phytoplankton and sedimentary diatoms, testate amoebae, cladocerans and ostracodes). The limnological and biological data thus obtained were complemented with additional information and compiled to generate an individual chart for each lake, summary data are also presented in Table 1. Charts display information on climate, limnology, main aquatic bioindicator taxa present, and previous published work. Finally, numerical analyses were used to synthesize and analyze the limnological and climatic information. Description of items included in charts, and of numerical analysis performed follows:

\subsection{CLIMATE}

For all sites, meteorological data such as mean annual temperature, annual temperature range, total annual precipitation and annual evaporation were taken from the closest meteorological stations (SMN, 2015). Climate types for each site were identified according to the INEGI climate map (INEGI, 2008) which follows García, 2004.

\subsection{LIMNOLOGY}

The lake's origin was determined following bibliographical sources or inferred from field observations and Google Earth ${ }^{\circledR}$ satellite images in the case that there were not previous studies. The categories identified were: tectonic (by faulting), volcanic (crater, maars and natural dam) and reservoir (dike, artificial dam and river diversion). The surface of each water body was measured in the Google Earth ${ }^{\circledR}$ satellite images and when possible confirmed with bibliographical data.

Water depth $(\mathrm{m})$ was measured in the field using a portable depth sounder (Speedtech Instruments), but not always the maximum depth spot at each site was located. Maximum water depth for all sites was taken from bibliographical data when available or from our own depth measurements. Relative depth $\left(\mathrm{Z}_{\mathrm{r}}\right.$ in \%) was calculated with the formula:

$$
Z r=50 * Z \max * \sqrt{\pi} / \sqrt{(}(A o) \quad \text { Equation } 1
$$

where $Z_{\max }=$ maximum depth, and $A_{0}=$ surface area (Wetzel and Likens, 1991).

The lake's mixing pattern was taken from bibliographic data when available, otherwise it was assumed to be warm monomictic if water depth was $>8 \mathrm{~m}$, relative depth was $>1 \%$ and our temperature depth profiles confirmed stratification; if these criteria were not fulfilled, the lake was assumed to be warm polymictic (Lewis, 2000). If a thermocline and/or oxycline were detected, the depth (m) at which they occurred was specified. Water transparency was measured in the field as visibility $(\mathrm{m})$ using a Secchi disk.

Temperature $\left({ }^{\circ} \mathrm{C}\right)$, oxygen concentration $(\mathrm{mg} / \mathrm{L})$, $\mathrm{pH}$ and electric conductivity $(\mu \mathrm{S} / \mathrm{cm})$ depth 


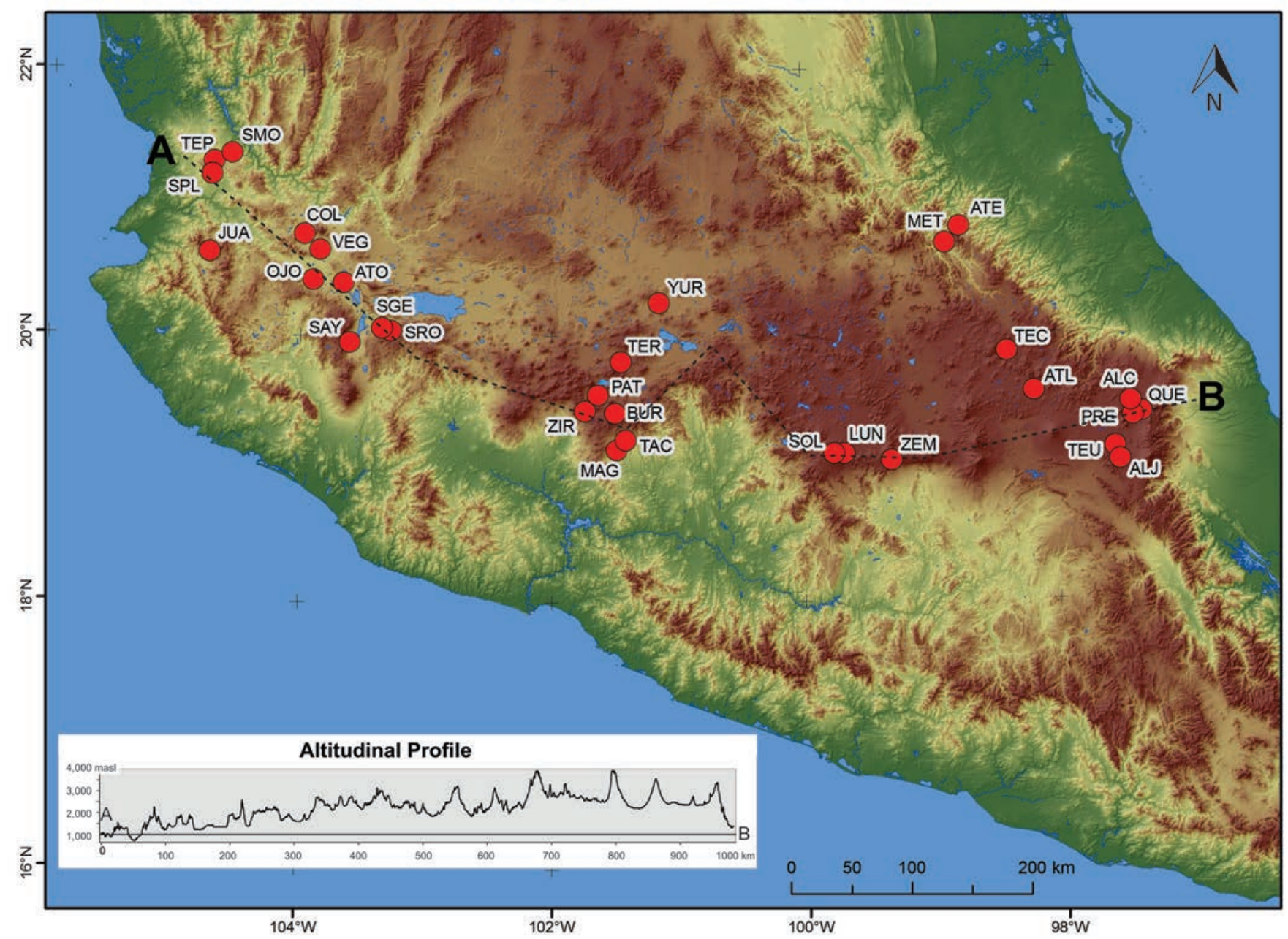

Figure 1 Map with the location of the 30 lakes studied along the Trans-Mexican Volcanic Belt, central Mexico. Abbreviations correspond to those in Table 1.

profiles were also measured in the field using a multiparametric probe (Hydrolab Quanta G). Temperature and oxygen data are presented as depth profiles in lakes where the sampling site was $>6 \mathrm{~m}$ deep, or in table format for shallower locations. Electric conductivity and $\mathrm{pH}$ are presented in tables, showing a littoral site (only measurement in small, shallow lakes), and a centric site which could have only surface (shallow lakes), or surface and bottom data (if depth $\geq 3 \mathrm{~m}$ ).

Water samples for chemical determinations and for phytoplankton analyses were collected using a Van Dorn-type sampling bottle from a littoral and from a centric site, with samples from surface $(0.5$ $\mathrm{m})$ and bottom of the water column ( $1 \mathrm{~m}$ above the sediments if depth $\geq 3 \mathrm{~m}$ ). Samples for cation determinations were acidified using concentrated $(55 \%) \mathrm{HNO}_{3}$. All samples were kept in refrigeration until analyzed in the laboratory. Major ions analyses were performed following standard procedures (APHA, 1995, 1998; APHA et al., 2005; Armienta et al., 2008).

Major ions concentrations are expressed in $\mathrm{mg} / \mathrm{L}$ but these data were also transformed to meq/L and then to percentages to determine ionic dominance (ion's relative concentrations), which was determined merging $\left[\mathrm{HCO}_{3}{ }^{-}\right]+\left[\mathrm{CO}_{3}{ }^{2-}\right]$ and $\left[\mathrm{Na}^{+}\right]+\left[\mathrm{K}^{+}\right]$.

Total dissolved inorganic carbon (DIC) was measured with an AutoMate carbonate preparation 
Table 1. Main limnological characteristics of 30 lakes studied along the Trans-Mexican Volcanic Belt, central Mexico. Salinity and trophic categories as defined in Table 1.

\begin{tabular}{|c|c|c|c|c|c|c|c|c|c|c|}
\hline Lake & Tag & Type & $\begin{array}{c}\text { Area } \\
\text { (ha) }\end{array}$ & $\begin{array}{l}\text { Maximum } \\
\text { depth (m) }\end{array}$ & $\begin{array}{c}\text { Relative } \\
\text { depth }(\%)\end{array}$ & $\begin{array}{c}\text { Dominant } \\
\text { anions }\end{array}$ & $\begin{array}{c}\text { Dominant } \\
\text { cations }\end{array}$ & pH & $\begin{array}{l}\text { Salinity } \\
\text { category }\end{array}$ & $\begin{array}{l}\text { Trophic } \\
\text { category }\end{array}$ \\
\hline Alberca de Tacámbaro & TAC & $\begin{array}{l}\text { Volcanic } \\
\text { (crater) }\end{array}$ & 8.2 & 28 & 8.7 & $\mathrm{HCO}_{3}^{-}$ & $\mathrm{Mg}^{2+}$ & 7.8 & Freshwater & Eutrophic \\
\hline Alberca de Teremendo & TER & $\begin{array}{l}\text { Volcanic } \\
\text { (crater) }\end{array}$ & 15 & 9 & 2.1 & $\mathrm{HCO}_{3}^{-}$ & $\mathrm{Na}^{+}-\mathrm{Mg}^{2+}$ & 8.3 & Freshwater & Hypertrophic \\
\hline Alchichica & ALC & $\begin{array}{l}\text { Volcanic } \\
\text { (maar) }\end{array}$ & 200 & 62 & 3.8 & $\mathrm{Cl}^{-}$ & $\mathrm{Na}^{+}$ & 8.3 & Hyposaline & Mesotrophic \\
\hline Aljojuca & ALJ & $\begin{array}{l}\text { Volcanic } \\
\text { (maar) }\end{array}$ & 42 & 51 & 7 & $\mathrm{HCO}_{3}^{-}$ & $\mathrm{Na}^{+}$ & 9.5 & Subsaline & Mesotrophic \\
\hline Atezca & ATE & $\begin{array}{l}\text { Volcanic } \\
\text { (dam) }\end{array}$ & 27 & 16 & 2.7 & $\mathrm{HCO}_{3}^{-}$ & $\mathrm{Ca}^{2+}$ & 9.3 & Freshwater & Mesotrophic \\
\hline Atlangatepec & ATL & $\begin{array}{l}\text { Reservoir } \\
\text { (dike) }\end{array}$ & 800 & 7 & 0.2 & $\mathrm{HCO}_{3}^{-}$ & $\mathrm{Na}^{+}$ & 7.7 & Freshwater & Eutrophic \\
\hline Atotonilco & ATO & Tectonic & 1370 & 0.5 & $<0.1$ & $\mathrm{HCO}_{3}^{-}$ & $\mathrm{Na}^{+}$ & 9.6 & Hyposaline & Mesotrophic \\
\hline Burro & BUR & $\begin{array}{l}\text { Probably } \\
\text { volcanic }\end{array}$ & 9 & 1 & 0.3 & $\mathrm{HCO}_{3}^{-}$ & $\mathrm{Na}^{+}$ & 6.9 & Freshwater & Eutrophic \\
\hline Colorada & COL & $\begin{array}{l}\text { Reservoir } \\
\text { (dike) }\end{array}$ & 410 & 3 & 0.1 & $\mathrm{HCO}_{3}^{-}$ & $\mathrm{Ca}^{2+}$ & 7.8 & Freshwater & Hypertrophic \\
\hline El Sol & SOL & $\begin{array}{l}\text { Volcanic } \\
\text { (crater) }\end{array}$ & 18 & 15 & 3.2 & $\mathrm{HCO}_{3}^{-}$ & $\mathrm{Ca}^{2+}$ & 7.2 & Freshwater & Oligotrophic \\
\hline Juanacatlán & JUA & $\begin{array}{l}\text { Volcanic } \\
\text { (dam) }\end{array}$ & 20 & 25 & 5 & $\mathrm{HCO}_{3}^{-}$ & $\mathrm{Ca}^{2+}$ & 9.2 & Freshwater & Mesotrophic \\
\hline La Luna & LUN & $\begin{array}{l}\text { Volcanic } \\
\text { (crater) }\end{array}$ & 2.5 & 10 & 5.6 & $\mathrm{HCO}_{3}^{-}$ & $\mathrm{Ca}^{2+}$ & 7.7 & Freshwater & Ultra-oligotrophic \\
\hline La Magdalena & MAG & $\begin{array}{l}\text { Reservoir } \\
\text { (dike) }\end{array}$ & 22 & 4 & 0.8 & $\mathrm{HCO}_{3}^{-}$ & $\mathrm{Ca}^{2+}$ & 8.8 & Freshwater & Hypertrophic \\
\hline La Preciosa & PRE & $\begin{array}{l}\text { Volcanic } \\
\text { (maar) }\end{array}$ & 91 & 46 & 4.3 & $\mathrm{HCO}_{3}^{-}$ & $\mathrm{Mg}^{2+}$ & 9.3 & Subsaline & Oligotrophic \\
\hline La Vega & VEG & $\begin{array}{l}\text { Reservoir } \\
\text { (dike) }\end{array}$ & 1610 & 6 & 0.1 & $\mathrm{HCO}_{3}^{-}$ & $\mathrm{Na}^{+}$ & 8.5 & Freshwater & Hypertrophic \\
\hline Metztitlán & MET & Tectonic & 2940 & 10 & 0.2 & $\mathrm{HCO}_{3}^{-}$ & $\mathrm{Ca}^{2+}$ & 8.9 & Freshwater & Eutrophic \\
\hline Ojo de Agua & OJO & $\begin{array}{l}\text { Reservoir } \\
\text { (dam) }\end{array}$ & 58 & 1.5 & 0.2 & $\mathrm{HCO}_{3}^{-}$ & $\mathrm{Ca}^{2+}$ & 8.5 & Freshwater & Eutrophic \\
\hline Pátzcuaro & PAT & $\begin{array}{l}\text { Volcanic } \\
\text { (dam) }\end{array}$ & 10000 & 9.4 & 0.1 & $\mathrm{HCO}_{3}^{-}$ & $\mathrm{Na}^{+}$ & 8.3 & Subsaline & Hypertrophic \\
\hline Quechulac & QUE & $\begin{array}{l}\text { Volcanic } \\
\text { (maar) }\end{array}$ & 64 & 40 & 4.4 & $\mathrm{HCO}_{3}^{-}$ & $\mathrm{Mg}^{2+}$ & 9 & Freshwater & Oligotrophic \\
\hline San Pedro Lagunillas & SPL & $\begin{array}{l}\text { Volcanic } \\
\text { (dam) }\end{array}$ & 296 & 7 & 0.4 & $\mathrm{HCO}_{3}^{-}$ & $\mathrm{Na}^{+}$ & 8.2 & Freshwater & Hypertrophic \\
\hline Santa Gertrudis & SGE & $\begin{array}{l}\text { Reservoir } \\
\text { (dike) }\end{array}$ & 50 & 2.3 & 0.3 & $\mathrm{HCO}_{3}^{-}$ & $\mathrm{Ca}^{2+}-\mathrm{Mg}^{2+}-\mathrm{Na}^{+}$ & 8 & Freshwater & Eutrophic \\
\hline Santa María del Oro & SMO & $\begin{array}{l}\text { Volcanic } \\
\text { (crater) }\end{array}$ & 370 & 65 & 3 & $\mathrm{HCO}_{3}^{-}-\mathrm{Cl}^{-}$ & $\mathrm{Na}^{+}$ & 8.6 & Subsaline & Mesotrophic \\
\hline Santa Rosa & SRO & $\begin{array}{l}\text { Reservoir } \\
\text { (dam) }\end{array}$ & 1.3 & 1.8 & 1.4 & $\mathrm{HCO}_{3}^{-}$ & $\mathrm{Mg}^{2+}$ & 9 & Freshwater & Mesotrophic \\
\hline Sayula & SAY & Tectonic & 10700 & 1 & $<0.1$ & $\mathrm{HCO}_{3}^{-}-\mathrm{Cl}^{-}$ & $\mathrm{Na}^{+}$ & 9.3 & Subsaline & Mesotrophic \\
\hline Tecocomulco & TEC & Tectonic & 1900 & 2 & 0.1 & $\mathrm{HCO}_{3}^{-}$ & $\mathrm{Na}^{+}$ & 8.8 & Freshwater & Eutrophic \\
\hline Tecuitlapa & TEU & $\begin{array}{l}\text { Volcanic } \\
\text { (maar) }\end{array}$ & 18 & 2.5 & 0.1 & $\mathrm{CO}_{3}{ }^{2-}$ & $\mathrm{Na}^{+}$ & 10.3 & Subsaline & Hypertrophic \\
\hline Tepetiltic & TEP & $\begin{array}{l}\text { Volcanic } \\
\text { (crater) }\end{array}$ & 132 & 2.5 & 0.2 & $\mathrm{HCO}_{3}^{-}$ & $\mathrm{Ca}^{2+}$ & 8.3 & Freshwater & Hypertrophic \\
\hline Yuriria & YUR & $\begin{array}{l}\text { Reservoir } \\
\text { (dam and river } \\
\text { diversion) }\end{array}$ & 5000 & 2.3 & $<0.1$ & $\mathrm{HCO}_{3}^{-}$ & $\mathrm{Na}^{+}$ & 8 & Freshwater & Eutrophic \\
\hline Zempoala & ZEM & $\begin{array}{l}\text { Volcanic } \\
\text { (dam) }\end{array}$ & 10 & 8 & 2.2 & $\mathrm{HCO}_{3}^{-}$ & $\mathrm{Ca}^{2+}$ & 8.8 & Freshwater & Mesotrophic \\
\hline Zirahuén & ZIR & $\begin{array}{l}\text { Volcanic } \\
\text { (dam) }\end{array}$ & 930 & 40 & 1.2 & $\mathrm{HCO}_{3}^{-}$ & $\mathrm{Ca}^{2+}-\mathrm{Mg}^{2+}-\mathrm{Na}^{+}$ & 6.5 & Freshwater & Oligotrophic \\
\hline
\end{tabular}


device. Approximately $5 \mathrm{~mL}$ of sample were weighed into septum top tubes and placed into the carousel. To purge the sample vial of atmospheric gas, a double needle assembly and $\mathrm{CO}_{2}$-free nitrogen carrier gas were used. The sample vial was injected with acid and evolved $\mathrm{CO}_{2}$ was carried through a silver nitrate scrubber to the coulometer where total $\mathrm{C}$ was measured.

Samples for ammonium and nitrates were acidified using concentrated $(98 \%) \mathrm{H}_{2} \mathrm{SO}_{4}$. Ammonium $\left(\mathrm{N}_{-} \mathrm{NH}_{4}, \mathrm{Nessler}\right.$ 's method), nitrites $\left(\mathrm{NO}_{2}\right.$, diazotization), nitrates $\left(\mathrm{N}-\mathrm{NO}_{3}\right.$, brucine colorimetric method), total phosphorus (PT, persulfate digestion) and orthophosphate $\left(\mathrm{P}-\mathrm{PO}_{4}\right.$, ascorbic acid method) were determined in a Thermo Scientific GENESYS 20 Visible spectrophotometer. Silica $\left(\mathrm{SiO}_{2}\right)$ was colorimetrically determined by the molybdosilicate method. Nutrients concentrations are expressed as $\mathrm{mg} / \mathrm{L}$, merging $\left[\mathrm{N}_{-} \mathrm{NH}_{4}\right]$ $+\left[\mathrm{N}^{\left.-\mathrm{NO}_{3}\right]}+\left[\mathrm{N}_{3} \mathrm{NO}_{2}\right]\right.$ as dissolved inorganic nitrogen (DIN). Nutrient concentrations were also transformed to $\mu \mathrm{M}$ and molar nutrient ratios were calculated (DIN:PT, DIN:P-PO, $\mathrm{SiO}_{2}: \mathrm{DIN}$, $\mathrm{SiO}_{2}: \mathrm{P}_{-}-\mathrm{PO}_{4}$ ).

Samples for chlorophyll $a$ determinations were filtered in the field with a Whatman GF/C membrane and filters were kept in refrigeration and darkness until arriving to the laboratory. Extraction was made using methanol (90\%), concentrations were measured with a spectrophotometer (Thermo Scientific Genesys 20 Visible) and determined using Holden's equations (Meeks, 1974); chlorophyll $a$ concentrations are expressed as $\mathrm{mg} / \mathrm{m}^{3}$. Salinity category for each lake was determined following their total dissolved solids (TDS) values
(Fritz, 2007; Kolbe, 1927) and trophic category was determined based on their superficial chlorophyll $a$ concentrations (OECD, 1982) (Table 2).

\subsection{BIOLOGICAL ANALYSIS}

Water samples for phytoplankton analyses were collected at the same time as those for chemical determinations and preserved using Lugol's solution. Two aliquots of $0.1 \mathrm{~mL}$ from each phytoplankton sample were analyzed using a compound microscope (Nikon Eclipse 80i) at 600x to 1000x. Semiquantitative abundance determinations were based on the following rankings: rare (1 specimen), scarce $(2-10)$, abundant $(11-50)$ and very abundant $(>50)$. In this study, only the species falling in the last two categories (abundant and very abundant) are reported. Organisms were identified using specialized bibliography for each (Komárek and Anagnostidis, 1999, 2005; Komárek et al., 1983; Krammer and Lange-Bertalot, 1991a, b; Krammer and Lange-Bertalot, 1997; Krammer and Lange-Bertalot, 1999; Prescott, 1962).

Surface sediments were collected from all lakes at a littoral (only sample in small, shallow lakes) and a central station for biological (diatoms, testate amoebae, cladocerans and ostracodes) determinations; if water depth was very shallow $(<1 \mathrm{~m})$ sediment was collected directly with a spatula and if deeper with an Ekman dredge, taking care of collecting only the topmost sediment. Sediments samples for testate amoebae and ostracodes were preserved with anhydrous ethanol and all samples were kept refrigerated until analyzed in the laboratory.

Table 2. Boundary values criteria for salinity (Kolbe, 1927; Fritz, 2007) and trophic (OECD, 1982) categories.

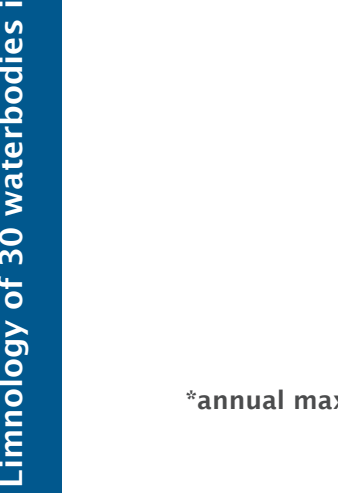
Salinity

\begin{tabular}{l|c|c|c|c|c|}
\hline Category & Freshwater & Subsaline & Hyposaline & Mesosaline & Hypersaline \\
\hline TDS $(\mathbf{m g} / \mathbf{L})$ & $\leq 500$ & $500-3000$ & $3000-20000$ & $20000-50000$ & $>50000$ \\
\hline Trophic category & \multicolumn{5}{|l|}{} \\
\hline Category & Ultra-oligotrophic & Oligotrophic & Mesotrophic & Eutrophic & Hypertrophic \\
\hline Chl $\boldsymbol{a}^{*}\left[\mathrm{mg} / \mathrm{m}^{3}\right]$ & $\leq 2.5$ & $2.5-8.0$ & $8.0-25$ & $25-75$ & $\geq 75$
\end{tabular}


Diatoms were extracted from $1 \mathrm{~cm}^{3}$ sediment samples. Sediment was freeze-dried, weighed and treated with $\mathrm{HCl}, \mathrm{H}_{2} \mathrm{O}_{2}$ and $\mathrm{HNO}_{3}$ to eliminate carbonates and organic matter. Permanent slides were mounted with $200 \mu \mathrm{L}$ aliquots of final solution, using Naphrax ${ }^{\circledR}$ as mounting medium. Counts of a minimum of 400 individuals were performed using an Olympus BX50 microscope (1000x). Species relative abundances were calculated and only the most abundant species, those accounting for $50 \%$ of the counts in each sample, were reported. Species identification was based on specialized literature (Gasse, 1986; Krammer and Lange-Bertalot, 1991a, b; Krammer and Lange-Bertalot, 1997; Krammer and Lange-Bertalot, 1999).

Testate amoebae were extracted from $2 \mathrm{~cm}^{3}$ samples with a fine brush under a stereomicroscope (Zeiss STEMI 2000-G Schott SeriesEasyLED) at $64 \mathrm{x}$ to $100 \mathrm{x}$. Identification was made following specialized literature (Alcocer et al., 2000b; Charman et al., 2000; Kumar and Dalby, 1998; Lee et al., 2000; Ogden and Hedley, 1980). All the tests found were counted, but only the genera or species for which more than 100 specimens were found are included in this study.

For cladocerans analysis, $1 \mathrm{~cm}^{3}$ of sediment was heated in a $10 \% \mathrm{KOH}$ solution and stirred for 20 -30 min. Treated samples were washed through a $38 \mu \mathrm{m}$ sieve, and then analyzed using an Olympus BX50 microscope at 100x to 400x. All Cladocera remains were counted (headshields, shells, ephippia, postabdomens) and the most abundant body part of each species was considered representative of the number of individuals, with a minimum of 200 individuals counted per sample. Identification and nomenclature of Cladocera remains was based on specialized literature (Cervantes-Martinez et al., 2000; Elías-Gutiérrez et al., 2008; Sinev and Zawisza, 2013). In this study, only the taxon with the highest frequency in each sample was reported, except in the samples were two species had equally high abundances, in these cases both taxa were reported.

Ostracode abundance was determined in $50 \mathrm{~cm}^{3}$ sediment samples by washing them through a 63 $\mu \mathrm{m}$ mesh sieve and separating adult valves using fine brushes under an Olympus SZX12 stereoscope (40x to $60 \mathrm{x})$. Ostracodes valves were stored in micropaleontological slides, specimens with well-preserved soft parts were kept at $5^{\circ} \mathrm{C}$ in small Eppendorf vials filled with $96 \%$ ethanol. For identification to genus level, hard parts were studied in detail and well-preserved specimens were dissected (Meisch, 2000). Identifications followed specialized literature (Forester et al., 2015; Pérez et al., 2011; Pérez et al., 2015). In this work, only the three most abundant genera $>100$ adult and juvenile valves in $50 \mathrm{~cm}^{3}$ of sediment) at each site were reported.

\subsection{PREVIOUS WORK}

A bibliography search for published papers for each lake was done; if the waterbodies had been extensively studied, only some of the most recent publications were selected.

\subsection{NUMERICAL ANALYSIS}

The dataset was synthesized through a Principal Component Analysis (PCA), which was performed using geographic (latitude, longitude, altitude), climatic (mean annual temperature, mean annual precipitation, mean annual evaporation) and limnological data (lake area, maximum depth, water transparency, chlorophyll $a$, average surface and bottom TDS, DIN and TP and average water column temperature, dissolved oxygen, $\mathrm{pH}$ and electric conductivity) from the 30 studied localities. Subsequently, another PCA was run excluding geographic location (latitude, longitude and altitude). The ordination of sites in both PCAs was compared through the Procrustes technique, a method that consists of fixing the first ordination, whereas the second is rotated using its origin as the vertex and aiming to minimize the distance between the same sites in both ordinations (Borcard et al., 2011). All analyses were performed using Package 'vegan' (Oksanen et al., 2015) in R (R Development Core Team, 2009). 


\section{Results}

An example of the charts made for each lake is presented in Figure 2, and the full set of individual charts for all the lakes is presented in alphabetic order in Electronic Supplement 1. Several of these waterbodies have been listed as Ramsar sites (Atotonilco, Sayula, Atlangatepec, Tecocomulco, Yuriria, La Vega, Metztitlán and Pátzcuaro), which shows the increasing concern for studying and preserving these ecosystems. However, to the best of our knowledge, this is the first published record of the basic limnological characteristics of some of the lakes (Alberca de Teremendo, Burro, Colorada, La Magdalena, Ojo de Agua, Santa Rosa, Santa Gertrudis, Tepetiltic) and for many this is the first record of their aquatic bioindicator's diversity, mostly for testate amoebae and cladocerans (full taxonomic and distribution list in Electronic Supplement 2). A summary of the lake's main characteristics is presented in Table 1.

Alberca de Tacámbaro (TAC), Michoacán $19^{\circ} 12^{\prime} 38^{\prime \prime} \mathrm{N}, 101^{\circ} 27^{\prime} 33^{\prime \prime} \mathrm{W}, 1475$ masl

\section{Climate}

Warm, sub-humid, summer rains

(A)C $\left(w_{1}\right)(w)$

Mean Annual Temperature $\quad 19.1^{\circ} \mathrm{C}$

Temp. Range 16.8 (Jan) -21.8 (May) ${ }^{\circ} \mathrm{C}$

Annual Precipitation

Annual Evaporation

\section{Limnology}

Lake type

Area

Maximum Depth

Relative Depth

Mixing pattern

Thermocline and oxycline

Transparency

lonic dominance

Salinity category

Trophic category Nutrient ratios

\begin{tabular}{|c|c|}
\hline $\begin{array}{r}{\left[\mathrm{HCO}_{3}^{-}\right]} \\
{\left[\mathrm{Mg}^{2+}\right]>\left[\mathrm{Ca}^{2+}\right]} \\
\\
\quad \text { Fres } \\
\text { Eutr }\end{array}$ & $\begin{array}{l}>\left[\mathrm{Na}^{+}\right] \\
\text {hwater } \\
\text { ophic }\end{array}$ \\
\hline DIN:TP & $0.1: 1$ \\
\hline DIN:P-PO & $17: 1$ \\
\hline $\mathrm{SiO}_{2}: \mathrm{DIN}^{4}$ & $530: 1$ \\
\hline $\mathrm{SiO}_{2}: \mathrm{P}-\mathrm{PO}_{4}$ & $8400: 1$ \\
\hline
\end{tabular}

Volcanic (crater)

$8.2 \mathrm{ha}$

$28 \mathrm{~m}^{\mathrm{b}}$

$8.7 \%$

Warm monomictic ${ }^{c}$

$\sim 5 \mathrm{~m}$

$1172 \mathrm{~mm}$

$1452 \mathrm{~mm}$
Chemical parameters

\begin{tabular}{lccc}
\hline Variable & Littoral & Surface & Bottom \\
\hline $\mathrm{pH}$ & $\mathrm{ND}$ & 7.8 & 7.3 \\
$\mathrm{EC}$ & $\mathrm{ND}$ & 182 & 208 \\
Total Alk & 128 & 115 & 122 \\
$\mathrm{CO}_{3}{ }^{2-}$ & 27 & 31 & $\mathrm{LDL}$ \\
$\mathrm{HCO}_{3}{ }^{-}$ & 102 & 76 & 149 \\
$\mathrm{SO}_{4}{ }^{2-}$ & 4.1 & 4.0 & $\mathrm{LDL}$ \\
$\mathrm{Cl}^{-}$ & 4.3 & 3.1 & 2.7 \\
$\mathrm{Na}^{+}$ & 9.2 & 8.7 & 7.8 \\
$\mathrm{~K}^{+}$ & 3.2 & 3.0 & 2.9 \\
$\mathrm{Ca}^{2+}$ & 16 & 16 & 19 \\
$\mathrm{Mg}^{2+}$ & 14 & 14 & 14 \\
$\mathrm{TDS}$ & 163 & 143 & 139 \\
\hline
\end{tabular}

Units: $E C$ in $\mu S / \mathrm{cm}$, Total Alkalinity in $\mathrm{mg} / \mathrm{L}$ $\mathrm{CaCO}_{3}$, ionic concentrations and TDS in $\mathrm{mg} / \mathrm{L}$

\section{Trophic parameters}

\begin{tabular}{lccc}
\hline \multicolumn{1}{c}{ Variable } & Littoral & Surface & Bottom \\
\hline $\mathrm{DIC}$ & 26 & 23 & 36 \\
$\mathrm{SiO} 2$ & 53 & 52 & 51 \\
$\mathrm{DIN}$ & $\mathrm{ND}$ & 0.02 & 1.93 \\
$\mathrm{TP}$ & $\mathrm{ND}$ & 0.10 & 0.10 \\
$\mathrm{P}-\mathrm{PO} 4$ & $\mathrm{ND}$ & 0.003 & 0.01 \\
Chlorophyll a & $\mathrm{ND}$ & 38.9 & 15.8 \\
\hline Units: $\mathrm{DIC}$ in $\mu \mathrm{gC} / \mathrm{g}, \mathrm{SiO}_{2,} \mathrm{DIN}^{\mathrm{TP}}, \mathrm{P}^{-} \mathrm{PO}_{4}$ in \\
mg/L and Chlorophyll a in $\mathrm{mg} / \mathrm{m}^{3}$
\end{tabular}

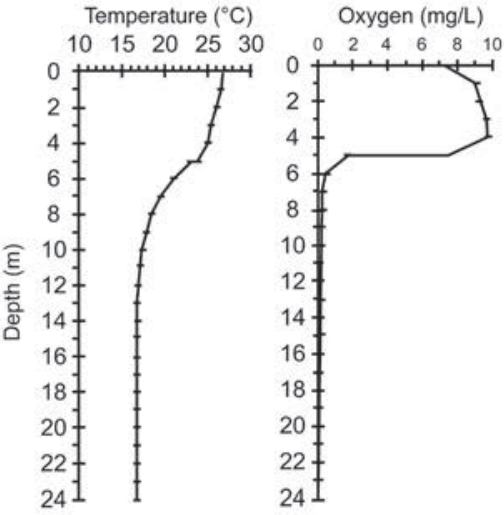

Main taxa in this study Phytoplankton.

Achnanthidium

minutissimum, Staurastrum sp., Woronichinia sp.

Diatoms. Achnanthidium minutissimum

Testate amoebae.

Centropyxis aculeata

Cladocerans. Bosmina

longirostris

Ostracodes. Cypridopsis,

Potamocypris

\section{Previous work}

Ortiz-Rubio, 1906; Hernández-Morales et al., b2008, 2009, '²011, 2014; Caballero et al., 2016.

Figure 2 Climatic and limnological data of Alberca de Tacámbaro. $\boldsymbol{a}$ and $\boldsymbol{b}$ indicate the bibliographical source of the data. lonic dominance includes ions present at $>5 \%$ relative concentrations in meq/L, in italics are ions between 5 and $25 \%$; "_“" was used when ionic relative concentrations were similar; ">" when they were less than double and ">>" when they were higher than double. LDL = Lower Detection Limit: $0.01 \mathrm{mg} / \mathrm{L} \mathrm{CO}_{3}{ }^{2}, 4 \mathrm{mg} / \mathrm{L} \mathrm{SO}_{4}{ }^{2}$. ND = Not Determined. Date of sampling: June 17, 2011. 


\section{Discussion}

\subsection{DISTRIBUTION AND MORPHOMETRIC GHARACTERISTICS}

The study covered 30 lakes within a latitudinal band from $19^{\circ} 00^{\prime}$ to $21^{\circ} 20^{\prime} \mathrm{N}$ and in longitude from $97^{\circ} 20^{\prime}$ to $104^{\circ} 40^{\prime} \mathrm{W}$. They were distributed along a $\sim 3550 \mathrm{~m}$ altitudinal gradient, from 737 masl (Santa María del Oro) to 4283 masl (La Luna and $\mathrm{El} \mathrm{Sol})$. Most of the lakes were volcanic in origin (5 maars, 6 crater lakes and 7 volcanic dams), followed by reservoirs (8) and tectonic lakes (4). About a third of the lakes were shallow $(<6 \mathrm{~m})$, some of them with just or under $1 \mathrm{~m}$ deep, these shallower lakes were mostly reservoirs (e.g. Ojo de Agua) or tectonic in origin (e.g. Atotonilco). Another third included some of the deepest lakes $>25$ $\mathrm{m}$ ) in central Mexico, and these were mostly volcanic craters or maars, like Alchichica and Santa María del Oro (62 and $65 \mathrm{~m}$ deep, respectively).

There was a good agreement between the measured and the bibliographic depths in all the lakes. Regarding areas, those estimated using Google Earth ${ }^{\circledR}$ also had a good agreement with the available bibliographical data, with discrepancies only at four sites. For lake Tecocomulco the bibliography reports a slightly smaller surface (1900 vs. 1769 ha, Ramsar, 2003), this relatively small difference $(<10 \%)$ can be explained as Tecocomulco is a large lake with ample inundation areas which can be flooded or dry depending on season and/or inter-annual climatic variability. For La Vega and Yuriria the bibliography reports larger areas (La Vega: 1610 vs. 1950 ha, Ramsar, 2011 ; and Yuriria: 7200 vs. 9500 ha, Ramos and Novelo, 1993) however, these water bodies are dams, which areas can easily change due to human management. For lake La Luna, the bibliography also reports a larger area (2.5 vs. 3.1 ha, Alcocer et al., 2004), but there is no discrepancy regarding its depth to confirm any change in this lake's morphometry.

\subsection{HYDROGHEMISTRY}

Waterbodies covered a wide range of hydrochemical characteristics; at the time of sampling (rainy season) most of them were alkaline $(\mathrm{pH}>7.5)$, and some even reached extremely alkaline $\mathrm{pH}$ values (> 9.5, Alchichica, Aljojuca, Atotonilco, Atezca, Tecuitlapa); only a few had $\mathrm{pH}$ values around or below 7 (El Sol 7.2, Burro 6.9, Zirahuén 6.5, La Luna 6.3).

Most of them were freshwater lakes, nine with particularly low mineralization (TDS $<100 \mathrm{mg} / \mathrm{L}$, Atezca, Burro, El Sol, Juanacatlán, La Magdalena, La Luna, Tepetiltic, Zempoala, Zirahuén) but there were also six subsaline (Aljojuca, La Preciosa, Pátzcuaro, Santa María del Oro, Sayula, Tecuitlapa) and two hyposaline (Alchichica, Atotonilco). Except for Colorada, the lakes had low proportions of sulfates $(<25 \%)$ and, except for Alchichica, they were dominated by carbonates and bicarbonates (Figure 3). The high sulfate proportion in Colorada is very unusual and could be a sign of anthropogenic pollution (Davies et al., 2002). Amongst the subsaline and hyposaline lakes there is a trend towards higher $\left[\mathrm{Cl}^{-}\right]$proportions, with Alchichica, the only lake dominated by chlorides, towards the end of this trend. Subsaline and hyposaline waterbodies had also low $\left[\mathrm{Ca}^{2+}\right]$ proportions (Figure 3) and except for La Preciosa (which was $\left[\mathrm{Mg}^{2+}\right]$ dominated) they were dominated by $\left[\mathrm{Na}^{+}\right]+\left[\mathrm{K}^{+}\right]$. Freshwater lakes do not have a clear ionic dominance, some were dominated by $\left[\mathrm{Na}^{+}\right]$ $+\left[\mathrm{K}^{+}\right]$(La Vega, San Pedro Lagunillas, Tecocomulco, Yuriria, Alberca de Teremendo, Atlangatepec), some by $\left[\mathrm{Ca}^{2+}\right]$ (Colorada, El Sol, La Luna, La Magdalena, Juanacatlán, Metztitlán, Ojo de Agua, Santa Gertrudis Tepetiltic, Zempoala, Zirahuén), and others by $\left[\mathrm{Mg}^{2+}\right]$ (Santa Rosa, Tacámbaro, Quechulac); however, those with the lowest TDS $(<100 \mathrm{mg} / \mathrm{l})$ were mostly $\left[\mathrm{Ca}^{2+}\right]$ dominated. This ionic dominance pattern suggest that the lowest TDS lakes represent the least evolved waters (Hardie and Eugster, 1970; Kilham, 1990), with ionic dominance determined mostly by weather- 

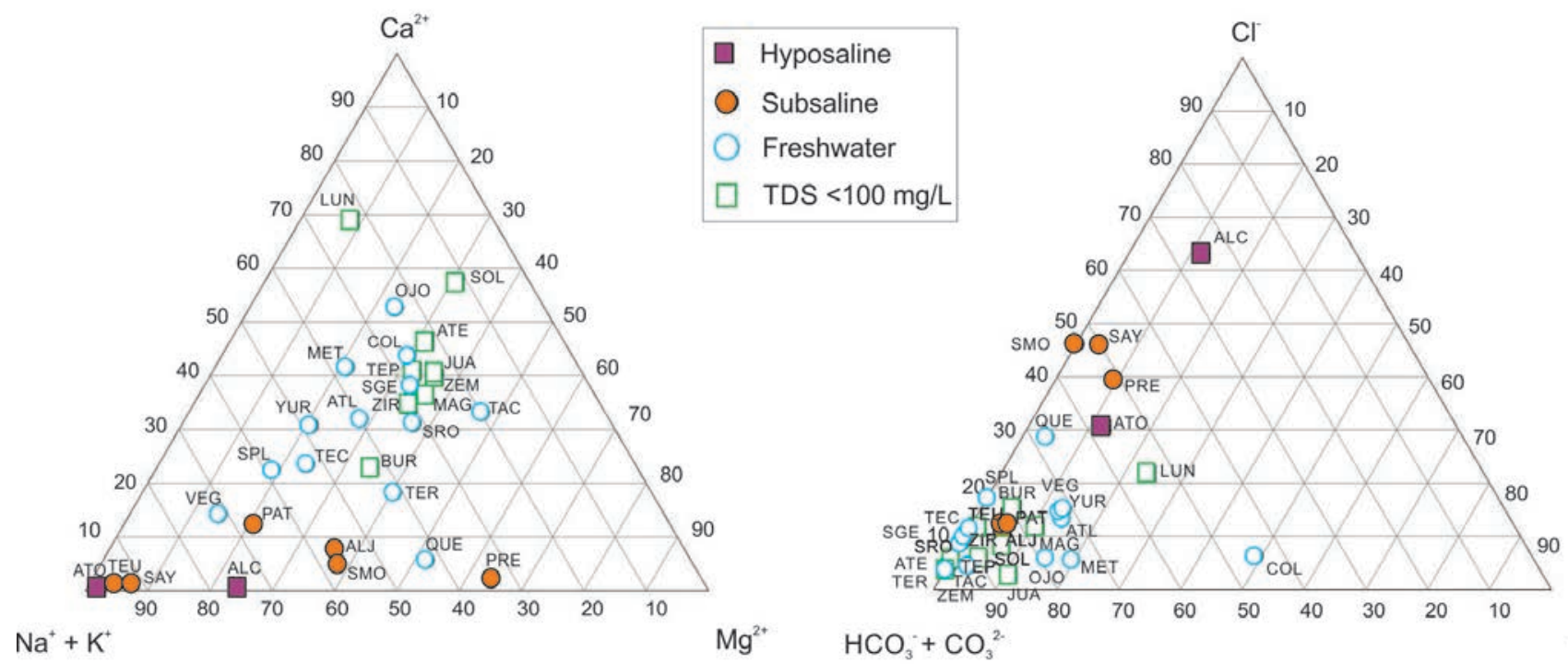

$\mathrm{HCO}_{3}+\mathrm{CO}_{3}^{2+}$

Figure 3 Triangular diagrams showing major cations and anions proportions in the $\mathbf{3 0}$ lakes studied along the Trans-Mexican Volcanic Belt, central Mexico. Abbreviations correspond to those in Table 1.

ing processes of the basaltic andesite rocks that dominate in the TMVB (Guilbaud et al., 2012), while the ionic composition of subsaline and hyposaline lakes is mostly controlled by evaporative concentration and carbonate precipitation (Eugster and Hardie, 1978; Kilham, 1990) leading to $\left[\mathrm{Cl}^{-}\right]-\left[\mathrm{CO}_{3}{ }^{2-}\right]-\left[\mathrm{Na}^{+}\right]$brines such as in Sayula or Alchichica.

\subsection{NUTRIENTS AND TROPHIC STATE}

According to the Redfield ratio $(\mathrm{N}: \mathrm{P}=16: 1)$ half of the waterbodies could have their primary productivity limited by nitrogen (DIN:P-PO $<16: 1$ ) at the time of sampling, while the other half by phosphorus. However, several lakes had concentrations of these elements above the limiting values of $0.1 \mu \mathrm{M}$ for $\mathrm{P}_{-} \mathrm{PO}_{4}$ and $7 \mu \mathrm{M}$ for DIN proposed by Reynolds (Reynolds, 1999) and therefore their productivity could not be considered to be $\mathrm{P}$ or $\mathrm{N}$ limited (Figure 4A). Most of the lakes had also high concentrations of $\mathrm{SiO}_{2}\left(\mathrm{SiO}_{2}: \mathrm{P}_{-} \mathrm{PO}_{4}\right.$ $<16: 1$ and $\mathrm{SiO}_{2}: \mathrm{DIN}<1: 1$, Xu et al., 2008, Figure $4 \mathrm{~B})$. Following these primary productivity nutrient limitation criteria (Redfield, 1958; Reynolds, 1999; Xu et al., 2008) 13 lakes could have some kind of primary productivity nutrient limitation at the time of sampling. Phosphorus limitation was the most frequent (8 lakes), followed by nitrogen (6) and silica (5); some of these lakes were co-limited by more than one of these nutrients: one lake was co-limited by nitrogen, phosphorus and silica (Zirahuén); two by phosphorus and nitrogen (Alberca de Tacámbaro and El Sol) and one by nitrogen and silica (Alchichica) (Figure 4). Atotonilco and Sayula were notable for having very high DIN and $\mathrm{P}_{-} \mathrm{PO}_{4}$ concentrations but a relatively low trophic level (both were mesotrophic), suggesting that productivity in these shallow lakes could be limited by other (unknown) factors.

Most of the lakes where nutrient levels showed possible limitation of primary productivity were mesotrophic (9), oligotrophic (4) or ultraoligotrohpic (1) and nearly half of the studied lakes (16) were either eutrohpic (8) or hypertrophic (8). It is worth noticing that in general the eutrophic to hypertrophic lakes were shallow $(<8 \mathrm{~m})$ and/or had low relative depth $(<1 \%)$. This raises the question of whether this high trophic level is a natural feature of the shallow lakes in the TMVB or if it is a response to antropogenic impact. Besides, shallow water bodies are probably the most sensitive to cli- 
matic changes, therefore this kind of lakes should be monitored regularly (at least once a year), to record changes in temperature, $\mathrm{pH}$, salinity, major ions and nutrient levels.

\subsection{BIOINDICATORS}

We report the distribution of 97 taxa of aquatic bioindicators: 40 corresponding to phytoplankton, 30 to diatoms in surface sediments, 8 testate
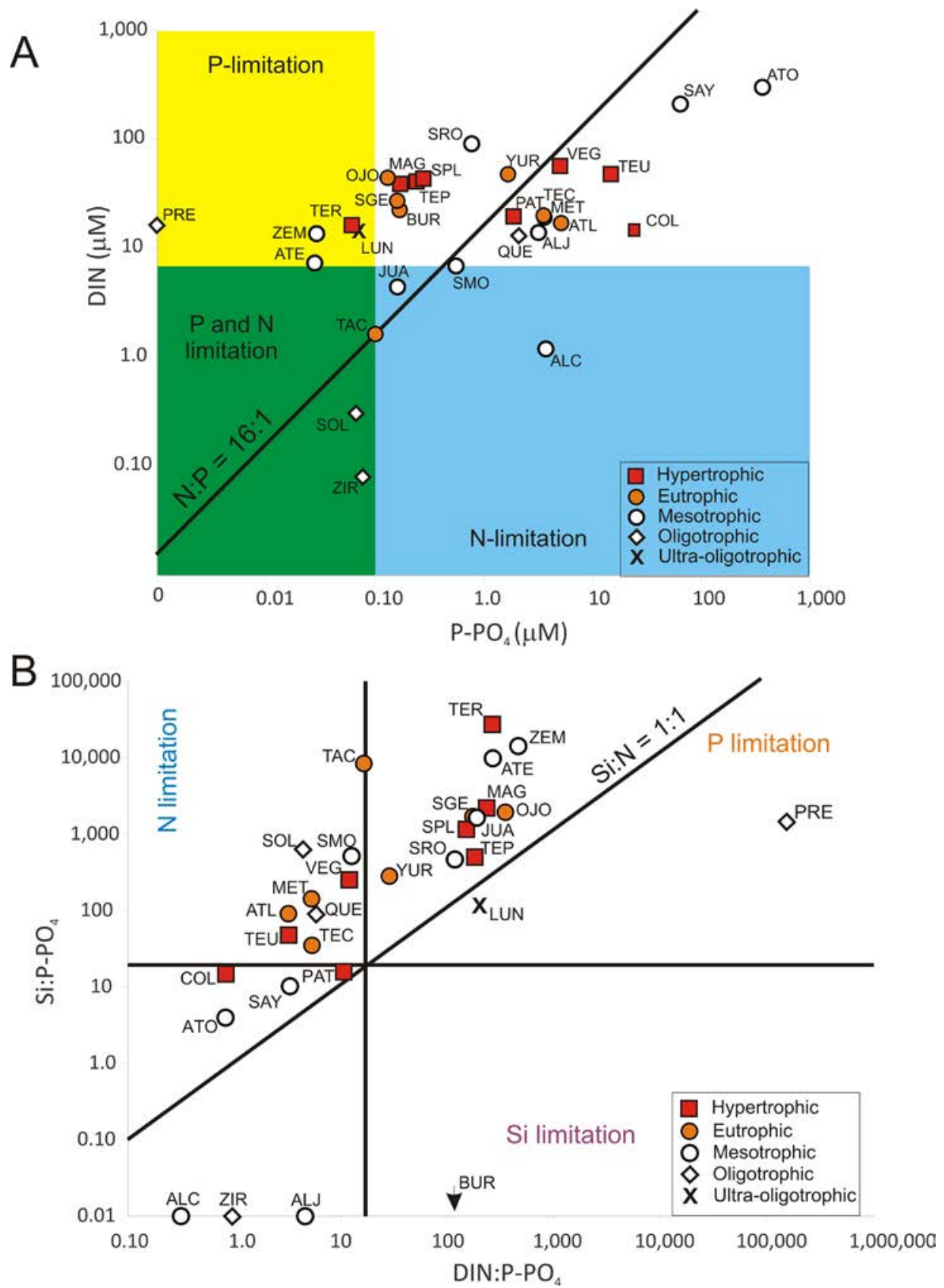

Figure 4 Nutrients in surface waters from the 30 lakes studied along the Trans-Mexican Volcanic Belt, central Mexico. A) P-PO ${ }_{4}$ and DIN molar concentrations diagram, diagonal line represents the Redfield (1958) N:P 16:1 ratio, shaded areas define nutrient limiting values

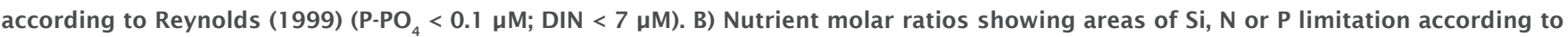
$\mathrm{Xu}$ et al. (2008), diatom growth could be limited by Si availability if $\mathrm{Si}: \mathrm{P}<16$ and/or Si:N $<1$. Abbreviations correspond to those in Table 1. 
amoebae, 11 cladocerans and 8 ostracodes (see Electronic Supplement 2).

Considering that only the most abundant taxa in each lake are reported in this work, we found that more than half of them (65) were abundant only at one site; this applies particularly to the phytoplankton and sedimentary diatom taxa. Amongst the phytoplankton, Peridinium Ehrenberg had the highest frequency of occurrence (abundant in 5 lakes) while in the sedimentary diatoms it was Aulacoseria granulata (Ehrenberg) Simonsen (abundant in 6 lakes). Testate amoeba, cladocerans and ostracoda had a higher number of taxa common to more than one lake and, taxa like Centropyxis aculeata (Ehrenberg) Stein, Alona quadrangularis (O.F. Müller), Bosmina longirostris (O.F. Müller), Daphnia longispina- group (O.F. Müller), Candona Baird and Limnocythere Brady had relatively high occurrence frequencies (abundant in $\geq 6$ lakes). Surprisingly some of the lakes that shared these high frequency taxa were located at opposite extremes in the TMVB; for example La Preciosa (east of TMVB) and Atotonilco (west of TMVB, Figure 1). However, this is only a first approach on the distribution of these bioindicators, and detailed, species level identifications supported by molecular studies would be necessary.

\subsection{GLIMATIC AND ENVIRONMENTAL GRADIENTS}

The PCA performed using geographical as well as climatic and limnological data (Figure 4A) showed a close correlation between both sets of variables. The longest environmental vectors, which correlate closely with the first axis (PG1 $27.17 \%$ ), were mean annual temperature and water temperature. Altitude on the other hand correlates negatively with PG1 and with temperature, as higher altitudes are associated with cooler climates. The second axis (PC2 $20.39 \%$ ) showed a positive correlation with precipitation and a negative correlation with total dissolved solids and electric conductivity. This relationship between lower precipitation and higher water ionic concentration has already been identified in previous works (Alcocer and Hammer, 1998; Armienta et al., 2008;
Hernández-Avilés et al., 2007) and is associated with the process of evaporative concentration that lake water undergoes in relatively dry climates, where evaporation exceeds precipitation (Hardie and Eugster, 1970).

Following these environmental gradients (temperature and precipitation) the PCA biplot (PC1 vs. PC2) separates the studied lakes into four quadrants $(\mathrm{Q}$ according to climate and limnological conditions (Figure 5). Cool, wet climates are associated with the lakes with the lowest TDS $(<100$ $\mathrm{mg} / \mathrm{l})$ in QII (e.g. La Luna and El Sol). Lakes in cool and relatively dry climates are in QIII (e.g. Alchichica, Aljojuca, Quechulac) and those in warmer and relatively dry climates are in QIV (Atotonilco, Sayula), both groups of lakes showing the highest TDS and EC values. Finally, lakes in warm, wet climates, with medium TDS are located in QI (Colorada, La Vega, San Pedro Lagunillas, Tepetiltic). Taking into account the chlorophyll $a$ vector, another ecological gradient becomes evident, with the eutrophic or hypertrophic lakes located in QI (moist and warm climates) while the (ultra)oligotrophic lakes are located in QII or QIII (cooler climates). High trophic levels in our data set seem to be at least partially related with climatic conditions, to warmer and moister climates where chemical weathering is intense and favors faster mobilization of chemical elements, including nutrients $(\mathrm{N}, \mathrm{P}, \mathrm{Si})$ from the basement rocks into the lakes (Lewis, 1996; Malmaeus et al., 2006; Xia et al., 2015).

It is interesting to note that in the PG1 vs. PG2 graph the lakes from opposite sides of the TMVB lie at adjacent quadrants (QIII and QIV) as they share high electric conductivities and total dissolved solids, associated to relatively dry climatic conditions. The bioindicator distribution previously discussed could be explained, therefore, as geographically distant lakes such as La Preciosa and Atotonilco share some physicochemical characteristics.

When the PCA is performed excluding geographical location (latitude, longitude and altitude) (Figure $4 \mathrm{~B}$ ) the variables associated to each axis 

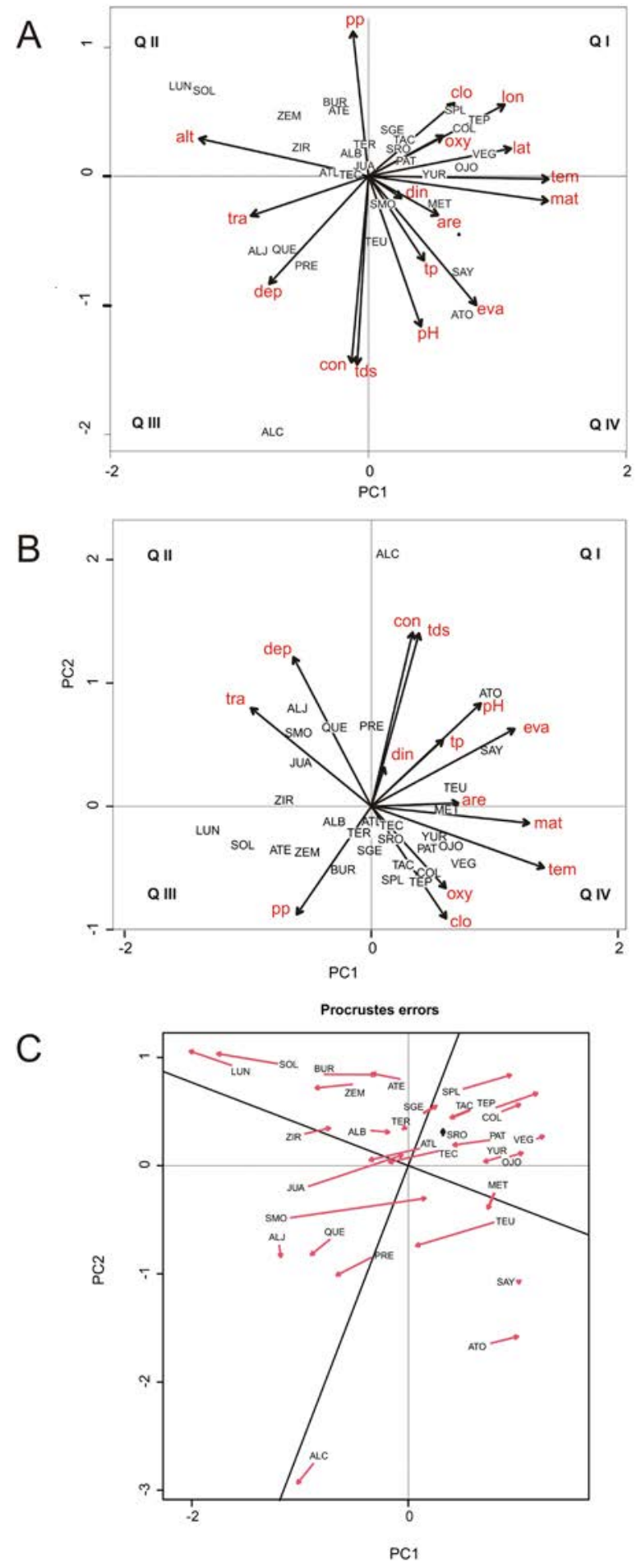

Figure 5 Principal component analysis (PCA) ordination of the 30 lakes studied along the Trans- Mexican Volcanic Belt, central Mexico; arrows indicate the geographic, climatic and limnological variables. A) PCA including latitude, longitude and altitude. B) PCA without latitude, longitude and altitude. C) Procrustes analysis showing the displacement of the sites between both ordinations. Abbreviations of waterbodies correspond to those in the chart of each waterbody (Figure 2 - 3). Abbreviations of environmental variables: alt, altitude; are, area; clo, chlorophyll $a$; con, electric conductivity; dep, maximum depth; din, dissolved inorganic nitrogen; eva, mean annual evaporation; lat, latitude; lon, longitude; mat, mean annual temperature; oxy, dissolved oxygen; pH, pH; pp, mean annual precipitation; tds, total dissolved solids; tem, water temperature; tp, total phosphorus; tra, transparency. Abbreviations correspond to those in Table 1. 
(PC1 25.32\%, PC2 $23.69 \%$ ) do not change, even though the PC2 orientation does. The Procrustes test allows us to determine which lakes are influenced the most by their geographic location, results are represented by arrows with their base indicating the location of the site in the first ordination, whereas the tip of the arrow indicates the localization of the same site in the second ordination. The lakes with the longest arrows (Figure 5C, e.g. Santa María del Oro, Juanacatlán and Tecuitlapa) are the ones that are more influenced by regional variables associated with their location (latitude, longitude and altitude) and would be the best choices for palaeoclimatic research while the shorter arrows (Alberca de Teremendo, Sayula, Santa Rosa, La Vega) indicate lakes which characteristics depend more on their local rather than regional variables.

It is only through the knowledge of the basic limnology and biodiversity of our lakes, generated via unified methodologies that guarantee comparable datasets, that more complex or detail studies can be proposed and developed leading to a better understanding, management and conservation of our country's water resources.

\section{Acknowledgements}

This research was funded by grants: CONACyT 167621, CONACyT 190519, PAPIIT-UNAM IA101912 and NGN 2014/13/B/ST10/02534. Itzel Sigala thanks the Posgrado de Ciencias Biológicas, UNAM and CONAGyT (GVU 294479) for financial support. Special thanks to Dr. Javier Alcocer from Proyecto de Investigación en Limnología Tropical, FES Iztacala, UNAM for the Secchi disk visibility and the temperature and oxygen depth profiles from Lake Alchichica and to Dr. Estela Cuna for the chlorophyll $a$ and the phytoplankton data from El Sol and La Luna. We also thank: Dr. Ma. Aurora Armienta and the staff in the Laboratorio de Química Analítica, Instituto de Geofisica, UNAM for major anions and $\mathrm{SiO}_{2}$ analysis; Ariadna Martinez and Daniela Cela from the "Red de Ecología Funcional" laboratory at the Instituto de Ecología, A.C. (INECOL), Xalapa, Mexico, for the nutrients analysis; Dr. Jason Curtis of the Department of Geological Sciences, University of Florida for the DIC analysis; Laura Luna González from the Digital Mapping Laboratory, Instituto de Geología, UNAM for the map elaboration and to Boon Graphics Producciones for images edition.

\section{References}

Adame, M.F., Alcocer, J., Escobar, E., 2008, Size-fractionated phytoplankton biomass and its implications for the dynamics of an oligotrophic tropical lake: Freshwater Biology, 53, 22-31.

Adrian, R., O’Reilly, C.M., Zagarese, H., Baines, S.B., Hessen, D.O., Keller, W., Livingstone, D.M., Sommaruga, R., Straile, D., Van Donk, E., 2009, Lakes as sentinels of climate change: Limnology and Oceanography, 54, 2283-2297.

Alcocer, J., Bernal-Brooks, F.W., 2002, Spatial and temporal heterogeneity of physical and chemical variables for an endorheic, shallow water body: Lake Pátzcuaro, México: Archiv für Hydrobiologie, 155, 239-253.

Alcocer, J., Bernal-Brooks, F.W., 2010, Limnology in Mexico: Hydrobiologia, 644, 15-68.

Alcocer, J., Escobar, E., Lugo, A., 2000a, Water use (and abuse) and its effects on the craterlakes of Valle de Santiago, Mexico: Lakes and Reservoirs Research and Management, $5,145-149$.

Alcocer, J., Escobar-Briones, E., Peralta, L., Álvarez, F., 2002, Population structure of the macrobenthic amphipod Hyalella azteca Saussure (Crustacea: Peracarida) on the littoral zone of six crater lakes, in EscobarBriones, E., Álvarez, F. (eds.), Modern approaches to the study of Crustacea: New York, Springer, 111-115. 
Alcocer, J., Escobar, E., Oseguera, L.A., 2008, Acoplamiento pelágico-bentónico: respuesta de la zona bentónica profunda a la sedimentación del florecimiento invernal de diatomeas en el lago oligotrófico Alchichica, Puebla, México: Hidrobiologica, 18, 115-122.

Alcocer,J., Filonov, A.E., 2007, A note on the effects of an individual large rainfall event on saline Lake Alchichica, Mexico: Environmental Geology, 53, 777-783.

Alcocer, J., Hammer, U., 1998, Saline lake ecosystems of Mexico: Aquatic Ecosystem Health \& Management, 1, 291-315.

Alcocer, J., Hernández, M.D.C., Oseguera, L.A., Escobar, E., 2015, On the ecology of Cletocamptus gomezi Suárez-Morales, BarreraMoreno \& Ciros-Pérez 2013 (Crustacea, Copepoda, Harpacticoida) micro-endemic to Lake Alchichica, Central Mexico: Journal of Limnology, 74, 302-309.

Alcocer, J., Lugo, A., 2003, Effects of El Niño on the dynamics of Lake Alchichica, central Mexico: Geofisica Internacional, 42, 523-528.

Alcocer, J., Lugo, A., Escobar, E., Sánchez, M.R., Vilaclara, G., 2000b, Water column stratification and its implications in the tropical warm monomictic Lake Alchichica, Puebla, Mexico: Verhandlungen des Internationalen Verein Limnologie, 27, 3166-3169.

Alcocer, J., Williams, W.D., 1996, Historical and recent changes in Lake Texcoco, a saline lake in Mexico: lnternational Journal of Salt Lake Research, 5, 45-61.

Alcocer, J., Oseguera, L., Escobar-Briones, E., Peralta, L., Lugo, A., 2004. Phytoplankton biomass and water chemistry in two highmountain tropical lakes in Central Mexico: Arctic, Antarctic, and Alpine Research 36: 342-346.

Alcocer, J., Ruiz-Fernández, A.C., Escobar, E., Pérez-Bernal, L.H., Oseguera, L.A., ArdilesGloria, V., 2014, Deposition, burial and sequestration of carbon in an oligotrophic, tropical lake: Journal of Limnology, 73(2), 223-235.

Almeida-Lenero, L., Hooghiemstra, H., Cleef, A.M., van Geel, B., 2005, Holocene climatic and environmental change from pollen records of lakes Zempoala and Quila, central Mexican highlands: Review of Palaeobotany and Palynology, 136, 63-92.

American Public Health Association (APHA), 1995, Standard methods for the examination of water and wastewater: Washington, D.C., American Public Health Association, 1015 p. American Public Health Association (APHA), 1998, Standard methods for the examination of water and wastewater: Washington, D.C., American Public Health Association, 1193 p. American Public Health Association (APHA), American Water Works Association (AWWA), Water Pollution Control Federation (WPCF), 2005, Standard Methods for the Examination of Water and Wastewater: Washington D.C., American Public Health Association, 1360 p. Ardiles, V., Alcocer, J., Vilaclara, G., Oseguera, L.A., Velasco, L., 2012, Diatom fluxes in a tropical, oligotrophic lake dominated by large-sized phytoplankton: Hydrobiologia, 679, 77-90.

Armienta, M.A., Vilaclara, G., De la CruzReyna, S., Ramos, S., Ceniceros, N., Cruz, O., Aguayo, A., Arcega-Cabrera, F., 2008, Water chemistry of lakes related to active and inactive Mexican volcanoes: Journal of Volcanology and Geothermal Research, 178, 249-258.

Arredondo-Figueroa, J.L., Borrego-Enríquez, L., Castillo-Domínguez, R., Valladolid-Laredo, M., 1983, Batimetría y morfometría de los lagos "maars" de la cuenca de Oriental, Puebla, México: Biotica, 8, 37-47.

Arredondo, J.L., 2002, Los axalapascos de la Cuenca Oriental, Puebla, in De la Lanza, E., García, C. (Eds.), Lagos y presas de México:Mexico City, Mexico, AGT Editor SA, 81-107. 
Arredondo-Figueroa, J.L., Borrego-Enríquez, L.E., Castillo-Domínguez, R.M., Valladolid-Laredo, M.A., 1983, Batimetría y morfometría de los lagos "maars" de la Guenca de Oriental, Puebla, México: Biotica, 8(1), 37-47.

Arredondo-Figueroa, J.L., Aguilar, D.C., 1987, Bosquejo histórico de las investigaciones limnológicas, realizadas en lagos mexicanos, con especial énfasis en su ictiofauna, in Gómez-Aguirre, S., Arenas V. (eds.), Contribuciones en hidrobiologia: Memoria de la Reunión "Alejandro Villalobos", 24 al 26 de octubre de 1983: Distrito Federal, Universidad Nacional Autónoma de México, Instituto de Biología, 91-133.

Banderas-Tarabay, A.G., 1997, Phycoflora of the tropical high-mountain lake El Sol, Central Mexico, and some biogeographical relationships: Hydrobiologia, 354, 17-40.

Bautista-Hernández, G.E., HernándezHernández, D.L., Monks S., Pulido-Flores G., 2008. Lago de Tecocomulco, in PulidoFlores, G., Monks, S., Miranda, R., Galicia, D. (eds.), Estudios científicos de Lago Tecocomulco, Hidalgo, y zonas aledañas: Pachuca, Ciencias al día 8, Universidad Autónoma del Estado de Hidalgo \& Universidad de Navarra, 15-22.

Bernal-Brooks, F., 2002, El lago de Zirahuén, in De la Lanza, E.G., García, C.J.L. (eds.), Lagos y presas de México: Distrito Federal, AGT Editor, 149-156.

Bernal-Brooks, F., MacCrimmon, H., 2000a, Lake Zirahuén (Mexico): an assessment of the morphometry change based on evidence of water level fluctuations and sediment inputs, in Munawar, M., Lawrence, S.G., Munawar, I.F., Malley, D.F. (eds.), Aquatic Ecosystems of Mexico: Status \& Scope: Leiden, Backhuys Publishers, 61-76.

Bernal-Brooks, F., MacCrimmon, H.R., 2000b, Lake Zirahuen (Mexico): A pristine natural reservoir visually insensitive to expected cultural eutrophication, in Munawar, M.,
Lawrence, S.G., Munawar, I.F., Malley, D.F., (eds.), Aquatic Ecosystems of Mexico: Status \& Scope: Backhuys Publishers. Leiden, 77-88.

Bernal-Brooks, F., Ruiz, S.G., 2007, El lago de Zirahuén, in De la Lanza, E.G. (ed.), Las aguas interiores de México. Conceptos y casos: Distrito Federal, AGT Editor, 253-265.

Bhattacharya, T., Byrne, R., Böhnel, H., Wogau, K., Kienel, U., Ingram, L., Zimmerman, S., 2015, Cultural implications of late Holocene climate change in the Cuenca Oriental, Mexico: Proceedings of the National Academy of Sciences, 112, 1693-1698.

Bischoff, J.L., Israde-Alcántara, I., GarduñoMonroy, V.H., Shanks Iii, W.C., 2004, The springs of Lake Pátzcuaro: chemistry, saltbalance, and implications for the water balance of the lake: Applied Geochemistry, 19, 1827-1835.

Bonilla-Barbosa,J.R., Novelo, R.A., 1995, Manual de identificación de plantas acuáticas del Parque Nacional Lagunas de Zempoala, México: Distrito Federal, Universidad Nacional Autónoma de México, Instituto de Biología, 168 p.

Borcard, D., Gillet, F., Legendre, P., 2011, Numerical Ecology with R: New York, Springer, $306 \mathrm{p}$.

Caballero, M.E., 1996, The diatom flora of two acid lakes in central Mexico: Diatom Research, 11, 227-240.

Caballero M., Lozano, S., Ortega, B., Urrurtia, J., Macias, J.L., 2005, La laguna de Tecocomulco: su historia durante los últimos 50000 años, in Huizar, A.H., Jiménez, F.E.J., Juárez, L.C. (eds.), La Laguna de Tecocomulco. Geo-Ecología de un desastre: Distrito Federal, Publicación Especial 3. Universidad Nacional Autónoma de México, Instituto de Geología, 49-72.

Caballero, M., Vázquez, G., Lozano-García, S., Rodríguez, A., Sosa-Nájera, S., RuizFernández, A.C., Ortega, B., 2006, Present limnological conditions and recent (ca. 340 
yr) palaeolimnology of a tropical lake in the Sierra de Los Tuxtlas, Eastern Mexico: Journal of Paleolimnology, 35, 83-97.

Castilla-Hernández, P., Torres-Alvarado, M.D.R., Herrera-San Luis, J.A., Cruz-López, N., 2014, Water quality of a reservoir and its major tributary located in east-central Mexico: International Journal of Environmental Research and Public Health, 11, 6119-6135.

Cervantes-Martinez, A., Gutierrez-Aguirre, M., Elias-Gutierrez, M., 2000, Description of Iliocryptus nevadensis (Branchiopoda, Anomopoda), a new species from high altitude crater lake in the volcano Nevado de Toluca, Mexico: Crustaceana, 354, 311-321.

Chacon-Torres, A., Rosas-Monge, C., 1998, Water quality characteristics of a high altitude oligotrophic Mexican lake: Aquatic Ecosystem Health \& Management, 1, 237-243.

Charman, D.J., Hendon, D., Woodland, W., 2000, The Identification of Testate Amoebae (Protozoa: Rhizopoda) in Peats: London, Quaternary Research Association, 147 p.

Conant, R., 2003, Observations on garter snakes of the Thamnophis eques complex in the lakes of Mexico's transvolcanic belt, with descriptions of new taxa: American Museum Novitates, Cover 1-64.

Conserva, M.E., Byrne, R., 2002, Late Holocene vegetation change in the Sierra Madre Oriental of central Mexico: Quaternary Research, 58, 122-129.

Couradeau, E., Benzerara, K., Moreira, D., Gerard, E., Kaźmierczak, J., Tavera, R., López-García, P., 2011, Prokaryotic and eukaryotic community structure in field and cultured microbialites from the alkaline Lake Alchichica (Mexico): PLoS One 6, e28767.

Davies, S.J., Metcalfe, S., Caballero, M., Juggins, S., 2002, Developing diatom-based transfer functions for Central Mexican lakes: Hydrobiologia, 467, 199-213.

Davies, S.J., Metcalfe, S.E., MacKenzie, A.B., Newton, A.J., Endfield G.H., Farmer J.G.,
2004, Environmental changes in the Zirahuén Basin, Michoacán, Mexico, during the last 1000 years: Journal of Paleolimnology, 31, 77-98.

Davies, S.J., Metcalfe, S.E., Bernal-Brooks, F., Chacón-Torres, A., Farmer, J.G., MacKenzie A.B., Newton, A.J., 2005, Lake sediments record sensitivity of two hydrologically closed upland lakes in Mexico to human impact: Ambio, 34(6), 470-475.

De la Lanza, E.G., Rodríguez, G., 2005, Analysis of the short term geo-environmental evolution of an endorreic basin using satellite images: the case of Tecocomulco Lagoon, Mexico: Investigaciones Geográficas, 58, 66-79.

De la Lanza-Espino, G., Gómez-Rodríguez, G., Islas, I.A., Escalante, R.V., Hernández, P.S., 2011, Analysis of the effect of El Niño and La Niña on Tecocomulco Lake, central basin, Mexico: Hidrobiológica, 21(3), 249-259.

Delgadillo, A.M. 1957, Avifauna de la Laguna de Sayula: Boletín Humedales de México, 9, 4-6.

Díaz-Pardo, E., Vazquez, G., López-López, E., 1998, The phytoplankton community as a bioindicator of health conditions of Atezca Lake, Mexico: Aquatic Ecosystem Health \& Management, 1, 257-266.

Díaz-Vargas, M., Arriaga, E.E.E., Quiróz, C.H., García, R.J., Molina, E.I., 2005, Caracterización de algunos parámetros físico químicos del agua y sedimento del Lago Zempoala, Morelos, México: Acta Universitaria, 15(2), 57-65.

Dimas-Flores, N., Alcocer, J., Ciros-Pérez, J., 2008, The structure of the zooplancton assemblages from two neighboring troical high mountain lakes: Journal of Freshwater Ecology, 23, 21-31.

Elías-Gutiérrez, M., Suarez-Morales, E., Gutiérrez-Aguirre, M.A., Silva-Briano, M., Granados-Ramírez, J.G., Garfias-Espejo, T., 2008, Cladocera y copepoda de las aguas continentales de México: Guía ilustrada: Distrito Federal, Comisión Nacional para 
el Conocimiento y Uso de la Biodiversidad UNAM, Facultad de Estudios SuperioresIztacala, El Colegio de la Frontera Sur, 322 p. Espinal, C.T., Sedeño, D.J.E., López, L.E.,2013, Evaluación de la calidad del agua en la Laguna de Yuriria, Guanajuato, México, mediante técnicas mutlivariadas: un análisis de valoración para dos épocas 2005, 2009-2010: Revista Internacional de Contaminación Ambiental, 29(3), 147-163.

Eugster, P.H., Hardie, L.A., 1978, Saline lakes, in

Lerman, A. (ed.), Lakes: chemistry, geology, physics: New York, Springer, 237-293.

Faugère-Kalfon, B., 1996, Entre Zacapu y Río

Lerma: culturas en una zona fronteriza:

Distrito Federal, Centre français d'études mexicaines et centraméricaines, $157 \mathrm{p}$.

Ferrari, L., Orozco-Esquivel, T., Manea, V., Manea, M., 2012, The dynamic history of the Trans-Mexican Volcanic Belt and the Mexico subduction zone: Tectonophysics, 522, 122-149.

Filonov, A., Tereshchenko, I., Alcocer, J., 2006, Dynamic response to mountain breeze circulation in Alchichica, a crater lake in Mexico: Geophysical Research Letters, 33, L07404.

Filonov, A., Tereshchenko, I., Alcocer, J., Monzón, G., 2015, Dynamics of internal waves generated by mountain breeze in Alchichica Crater Lake, Mexico: Geofísica Internacional, 54(1), 21-30.

Forester, R., Smith, A.J., Palmer, D.F., Curry, B., 2015, NANODe Version 1: North American Non-Marine Ostracode Database Biological Sciences, Earth Systems History, and Hydrologic Sciences. U.S. Geological Survey, Kent State University, National Science Foundation Programs, available at <http:// www.personal.kent.edu/ alisonjs/nanode/ index.htm>, consulted September 5, 2015.

Fritz, S., 2007, Salinity and climate reconstruction from diatoms in continental lake deposits, in Elias, S.A. (ed.), Encyclopedia of Quaternary Science: Oxford, Elsevier, 514-522.
García, E., 2004, Modificaciones al Sistema de Clasificación Climática de Köpen (para adaptarlo a las condiciones de la República Mexicana): Distrito Federal, Serie Libros No.6, Universidad Nacional Autonoma de México, Instituto de Geografía, 90 p.

García, R.J., Molina, A.F.I., Díaz, V.M., Quiroz, C.H., 2010, Componentes fitoplanctónicos y zoobentónicos en el lago Zempoala, Morelos, México: Acta Universitaria, 20(2), 23-30.

García-Nieto, E., Carrizales-Yañez, L., JuárezSantacruz, L., García-Gallegos, E., Hernández-Acosta, E., Briones-Corona, E., Vázquez-Cuecuecha, O.G., 2011, Plomo y arsénico en la subcuenca del Alto Atoyac en Tlaxcala, México: Revista Chapingo. Serie Ciencias Forestales y del Ambiente, 17, 7-17.

García-Rodríguez, J., Tavera, R., 2002, Phytoplankton composition and biomass in a shallow monomictic tropical lake: Hydrobiologia, 467, 91-98.

Gasse, F., 1986, East African diatoms, taxonomy, ecological distribution: Berlin, J. Cramer, 210 p.

González-Villela, R., De la Lanza, G.J., BanderasTarabay, A.G., Dynamic models of primary production in a tropical high-mountain lake: El Sol, Mexico, in Munawar, M., Lawrence, S.G., Munawar, I.F., Malley, D.F. (eds.), Aquatic Ecosystems of Mexico: Leiden, Status \& Scope, Backhuys Publishers, 119-134.

Guilbaud, M.N., Siebe, C., Layer, P., Salinas, S., 2012, Reconstruction of the volcanic history of the Tacámbaro-Puruarán area (Michoacán, México) reveals high frequency of Holocene monogenetic eruptions: Bulletin of Volcanology, 74, 1187-1211.

Hansen, A.M., 2012, Lake sediment cores as indicators of historical metal(loid) accumulation - A case study in Mexico: Applied Geochemistry, 27, 1745-1752.

Hansen, A.M., van Afferden, M., 2001, The Lerma-Chapala Watershed, Evaluation and Management: New York, Springer 
Sciences+Business Media, 385 p.

Hardie, L.A., Eugster, H.P., 1970, The evolution of closed-basin brines: Mineralogical Society of America Special Publication, 3, 273-290.

Hernández-Avilés, J.S., García-Calderón, J.L., de la Lanza, G., 2007, A proposed limnological classification of small water bodies based on the climate, in a tropical region: Mexico: Investigaciones Geográficas, Boletín del Instituto de Geografia, UNAM, 64, 63-74.

Hernández-Morales, R., Alvarado-Villanueva, R., Ortega-Murillo, M.R., Aguilera-Ríos, M.S., 2009, Ocurrencia nictimeral del fitoplancton en la epoca de lluvias en el lago tropical profundo de Tacámbaro, Michoacán, México: Biológicas, 11, 48-55.

Hernandez-Morales, R., Hidalgo-Anguiano, M., Ortega Murillo, M., Aguilera-Ríos, M.S., 2014. Factores abióticos que rigen la presencia y permanencia del género Microcystis en un lago tropical profundo: Biológicas, 16, 33-42.

Hernández-Morales, R., Ortega-Murillo, M.R., Sánchez,J.D., Alvarado-Valdez, G., AguileraRíos, M.S., 2011, Distribución estacional del fitoplancton en un lago cálido monomíctico en Michoacán, México: Biologicas, 13, 21-28.

Hernández-Morales, R., Ortega-Murillo, M., Alvarado-Villanueva, R., Sánchez-Hereida, J., Medrano-Zarco, F., 2008, Variación anual del fitoplancton en el Lago Cráter La Alberca de Tacámbaro, Michoacán, México: Biológicas, 10, 5-17.

Hernández, M.D.C., Alcocer, J., Oseguera, L.A., Escobar, E., 2014, Profundal benthic invertebrates in an oligotrophic tropical lake: different strategies for coping with anoxia: Journal of Limnology, 73(2), 387-399.

Huizar, A.R., Ruiz, G.J.E., 2005, Aspectos físicos y socioeconómicos de la subcuenca de Tecocomulco, in Huizar, A.H., Jiménez, F.E.J., Juárez, L.C. (eds.), La Laguna de Tecocomulco. Geo-Ecología de un desastre: Distrito Federal, Publicación Especial 3,
Universidad Nacional Autónoma de México, Instituto de Geología, 9-17.

Instituto Nacional de Estadística y Geografía (INEGI), 2008, Unidades climáticas escala 1:1000000 (online): Aguascalientes, INEGI, published/updated 2008, available at <http://www3.inegi.org.mx/sistemas/ biblioteca $/$ ficha.aspx?upc $=702825267568>$, downloaded September 5, 2015.

Kaźmierczak, J., Kempe, S., Kremer, B., LópezGarcía, P., Moreira, D., Tavera, R., 2011, Hydrochemistry and microbialites of the alkaline crater lake Alchichica, Mexico: Facies, 57, 543-570.

Kienel, U., Bowen, S.W., Byrne, R., Park, J., Bohnel, H., Dulski, P., Luhr, J.F., Siebert, L., Haug, G.H., Negendank, J.F.W., 2009, First lacustrine varve chronologies from Mexico: impact of droughts, ENSO and human activity since AD 1840 as recorded in maar sediments from Valle de Santiago: Journal of Paleolimnology, 42, 587-609.

Kilham, P., 1990, Mechanisms controlling the chemical composition of lakes and rivers: Data from Africa: Limnology and Oceanography, 35, 80-83.

Kolbe, R.W., 1927, Zur ökologie, morphologie und systematik der brackwasser-diatomeen: Die kieselalgen des Sperenberger salzgebiets: Jena Fischer, 146 p.

Komárek, J., Anagnostidis, K., 1999, Süsswasserflora von Mitteleuropa. Cyanoprokaryota 1. Chroococcales: Heidelberg, Akademischer Verlag, 548 pp.

Komárek,J.,Anagnostidis, K., 2005, Süsswasserflora von Mitteleuropa. Cyanoprokaryota 2/2nd part: Oscillatorialles: München, Elsevier Spektrum Akademischer Verlag, 759 p.

Komárek, J., Huber-Pestalozzi, G., Fott, B., 1983, Das Phytoplankton des Süßwassers: Systematik und Biologie. Teil 7: Hälfte 1. Chlorophyceae (Grünalgen), Ordnung: Chlorococcales: Schweizerbart, 1044 p.

Komárková, J., Tavera, R., 2003, Steady state of phytoplankton assemblage in the tropical 
Lake Catemaco (Mexico): Hydrobiologia, 502, 187-196.

Krammer, K., Lange-Bertalot, H., 1991a, Bacillariophyceae 2/3. Centrales, Fragilariaceae, Eunotiaceae: Stuttgart-Jena, Gustav Fischer Verlag, 576 p.

Krammer, K., Lange-Bertalot, H., 1991b, Bacillariophyceae 2/4. Achnanthaceae, Kritische Ergänzungen zu Navicula (Lineolatae) und Gomphonema: StuttgartJena, Gustav Fischer Verlag, 437 p.

Krammer, K., Lange-Bertalot, H., 1997, Bacillariophyceae 2/2. Bacillariaceae, Epithemiaceae, Surirellaceae: Stuttgart-Jena, Gustav Fischer Verlag, 596pp.

Krammer, K., Lange-Bertalot, H., 1999, Bacillariophyceae. 2/1. Naviculaceae: Stuttgart-Jena, Gustav Fischer Verlag, 876 pp.

Kumar, A., Dalby, A.P., 1998, Identification key for Holocene lacustrine arcellacean (thecamoebian) taxa: Palaeontologia Electronica, 1, 34.

Lee, J.J., Leedale, G., Bradbury, P., 2000, An Illustrated Guide to the Protozoa: Kansas, Society of Protozoologists, $1432 \mathrm{p}$.

Lewis, W.M., 1996, Tropical lakes: how latitude makes a difference, in Schiemer, F., Boland, K.T. (eds.), Perspectives in tropical limnology: Amsterdam, SPB Academic Publishing, 43-64.

Lewis, W.M., 2000, Basis for the protection and management of tropical lakes, Lakes \& Reservoirs: Research and Management, 5, $35-48$.

López-López, E., Sedeño-Díaz, J.E., Soto, C., Favari, L., 2011, Responses of antioxidant enzymes, lipid peroxidation, and $\mathrm{Na}^{+} / \mathrm{K}^{+}$ATPase in liver of the fish Goodea atripinnis exposed to Lake Yuriria water: Fish Physiology and Biochemistry, 37, 511-522.

Malmaeus, J.M., Blenckner, T., Markensten, H., Persson, I., 2006, Lake phosphorus dynamics and climate warming: A mechanistic model approach: Ecological Modelling, 190, 1-14.
Mancilla-Villa, O.R., Bautista-Olivas, A.L., Ortega-Escobar, H.M., Sánchez-Bernal, E.I., Can-Chulim, Á., Gutiérrez, G., Darío, R., Mikolaev, O., Manuel, Y., 2014, Hidrogeoquímica de salinas Zapotitlán y los lagos-cráter Alchichica y Atexcac, Puebla:Idesia, 32, 55-69.

Martínez-Almeida, V., Tavera, R., 2005, A hydrobiological study to interpret the presence of desmids in Lake Zirahuén, México: Limnologica, 35, 61-69.

Meeks, J., 1974, Chlorophylls, in Stewart, P. (ed.), Algal physiology and biochemistry, Oxford, Blackwell, 161-175.

Meisch, C., 2000, Freshwater Ostracoda of Western and Central Europe: Berlin, Spektrum Akademischer Verlag, 522 p.

Munguia, P., López, P., Fortes, I., 2005, Seasonal changes in waterbird habitat and occurrence in Laguna de Sayula, Western Mexico: The Southwestern Naturalist, 50(3), 318-322.

Niederberger, G., 1979, Early sedentary economy in the Basin of Mexico: Science, 203, 131-142.

Ogden, G., Hedley, R.H., 1980, An atlas of freshwater testate amoebae: Soil Science, 130, 176.

Oksanen, J., Blanchet, F.G., Kindt, R., Legendre, P., Minchin, P.R., O'Hara, R., Simpson, G.L., Solymos, P., Stevens, M., Wagner, H., 2015, vegan: Community Ecology Package (online): Viena, The R Project for Statistical Computing, published/updated 2017-0117, available at <http://cran.r-project.org/ package $=$ vegan $>$, downloaded September 5 , 2015.

Oliva, G., Lugo, A., Alcocer, J., Peralta, L., Sánchez, M.R., 2001, Phytoplankton dynamics in a deep, tropical, hyposaline lake: Hydrobiologia, 466, 299-306.

Oliva, M.G., Lugo, A., Alcocer, J., Cantoral-Uriza, E.A., 2008, Morphological study of Cyclotella choctawhatcheeana Prasad (Stephanodiscaceae) from a saline Mexican lake:Saline systems, 4, 1 . 
Organization for Economic Cooperation and Development (OECD), 1982, Eutrophication of waters. Monitoring, assessment and control: Paris, Organization for Economic Cooperation and Development, $154 \mathrm{p}$.

Ortega, B., Vázquez, G., Caballero, M., Israde, I., Lozano-García, S., Schaaf, P., Torres, E., 2010, Late Pleistocene: Holocene record of environmental changes in Lake Zirahuen, Central Mexico: Journal of Paleolimnology, 44, 745-760.

Ortega-Mayagoitia, E., Ciros-Pérez, J., SánchezMartínez, M., 2011, A story of famine in the pelagic realm: temporal and spatial patterns of food limitation in rotifers from an oligotrophic tropical lake: Journal of Plankton Research, 33, 1574-1585.

Ortiz-Rubio, P., 1906, El Axalapazco de Tacámbaro: Boletín de la Sociedad Gológica Mexicana, 2, 65-69.

Ortiz, P.C.F., Rendón, M.B., 2010, Espejo de los dioses: estudios sobre ambiente y desarrollo en la cuenca del lago de Zirahuén: Distrito Federal, Universidad Michoacana de San Nicolás de Hidalgo, 359 p.

Oseguera, L.A., Alcocer, J., Escobar, E., 2010, Seston flux in a tropical saline lake: Verhandlungen des Internationalen Verein Limnologie, 30, 1477-1481.

Peralta, L., Escobar, E., Alcocer, J., Lugo, A., 2002, Oligochaetes from six tropical crater lakes in Central Mexico: species composition, density and biomass:Hydrobiologia, 467, 109-116.

Pérez, L., Frenzel, P., Brenner, M., Escobar, J., Hoelzmann, P., Scharf, B., Schwalb, A., 2011, Late Quaternary (24-10 ka BP) environmental history of the Neotropical lowlands inferred from ostracodes in sediments of Lago Petén Itzá, Guatemala; Journal of Paleolimnology, 46, 59-74.

Pérez, L., Lozano-García, S., Caballero, M., 2015, Non-marine ostracodes from highland lakes in East-central Mexico: Revista de Biología Tropical, 63, 401-425.
Pérez-Arteaga, A., Gaston, K.J., Kershaw, M., 2002, Undesignated sites in Mexico qualifying as wetlands of international importance: Biological Conservation, 107, 47-57.

Pérez-Rodríquez, R., 1995, Moluscos dulceacuícolas de la Presa de Atlangatepec, Tlaxcala, México: Revista de la Sociedad Mexicana de Historia Natural, 46, 97-112.

Pérez-Rodríguez, R., Saldaña-Arias, A., BadilloSolís, A., 2001, Odonata (Insecta) de tres embalses del Estado de Tlaxcala: Revista de la Sociedad Mexicana de Historia Natural, 50, 25-31.

Prescott, G.W., 1962, Algae of the western Great Lakes area: Dubuque, WM.C. Brown Company Publishers, 1004 p.

Quiroz, C.H., Mondragón,E.O., Molina,A.I., García,R.J., Díaz,V.M., 2008， Dinámica espacio-temporal de oxígeno-temperatura en los lagos Zempoala y Tonatiahua: Acta Universitaria, 18(1), 57-65.

Quiroz-Flores, A., Ramírez-García, P., LotHelgueras, A., 2014. Variación anual de la biomasa de Nymphoides fallax Ornduff (Menyanthaceae) en la laguna de Tecocomulco, Hidalgo, México: Polibotánica, 37, 93-108.

Quisehuatl-Tepexicuapan, E., Ferrera-Cerrato, R., Silva-Rojas, H.V., Rodríguez-Zaragoza, S., Alarcón, A., Almaraz-Suárez, J.J., 2014, Free-living culturable bacteria and protozoa from the rhizoplanes of three floating aquatic plant species: Plant Biosystems An International Journal Dealing with all Aspects of Plant Biology: Official Journal of the Societa Botanica Italiana, DOI: 10.1080/11263504.2014.989282.

R Development Core Team, 2000, R: A language and environment for statistical computing, 3.1 (online): Viena, R Foundation for Statistical Computing, published/updated 2000-05-16, available at <http://www.r-project.org>, downloaded September 5, 2015.

Ramírez-García, P., Vázquez-Gutiérrez, F., 1989, Contribuciones al estudio limnobotánico de 
la zona litoral de seis lagos cráter del estado de Puebla: Anales del Instituto de Ciencias del Mar y Limnología de la Universidad Nacional Autónoma de México, 16, 1-16.

Ramos, V.L.J., Novelo, R.A., 1993, Vegetación y flora acuáticas de la laguna de Yuriria, Guanajuato, México: Acta Botánica Mexicana, 25, 61-79.

Ramos-Higuera, E., Alcocer, J., OrtegaMayagoitia, E., Camacho, A., 2008, Nitrógeno: elemento limitante para el crecimiento fitoplanctónico en un lago oligotrófico tropical: Hidrobiologica, 18, 105-113.

Ramsar, 2003, Servicio de Información sobre Sitios Ramsar. Laguna de Tecocomulco (online): Gland, Ramsar, published/updated 27-112003, available at <https://rsis.ramsar.org/ es/ris/1322>, downloaded September 5, 2015.

Ramsar, 2004a, Servicio de Información sobre Sitios Ramsar, Laguna de Sayula, available online at <https://rsis.ramsar.org/es/ ris/1338>, downloaded September 5, 2015.

Ramsar, 2004b, Servicio de Información sobre Sitios Ramsar, Laguna de Yuriria, available online at <https://rsis.ramsar.org/ ris/1361>, downloaded September 5, 2015.

Ramsar, 2006, Servicio de Información sobre Sitios Ramsar, Laguna de Atotonilco, available online at <https://rsis.ramsar.org/ ris/1607>, downloaded September 5, 2015.

Ramsar, 2011, Servicio de Información sobre Sitios Ramsar, Presa de Atlangatepec, available online at <https://rsis.ramsar.org/ ris/1986>, downloaded September 5, 2015.

Ramsar, 2011, Servicio de Información sobre Sitios Ramsar. Presa La Vega (online): Gland, Ramsar, published/updated 01-012011, available at <https://rsis.ramsar.org/ ris/2026>, downloaded September 5, 2015.

Redfield, A.C., 1958, The biological control of chemical factors in the environment: American Scientist, 64, 205-221.
Reynolds, C.S., 1999, Non-determinism to probability, or $\mathrm{N}: \mathrm{P}$ in the community ecology of phytoplankton nutrient ratios: Archiv für Hydrobiologie, 146, 23-35.

Rodríguez, M.J.J.R., Ritter, O.W., 2007, Presa Atlangatepec, in De la Lanza, E.G. (ed.), Las aguas interiores de México. Conceptos y casos: Distrito Federal, AGT, 517-530.

Rico-Sánchez, A.E., Rodríguez-Romero, A.J., López-López, E., Sedeño-Díaz, J.E., 2014, Patrones de variación espacial y temporal de los macroinvertebrados acuáticos en la Laguna de Tecocomulco, Hidalgo (México): Revista de Biología Tropical, 62 (Suppl. 2), 81-96.

Roy, P.D., Caballero, M., Lozano, R., Pi, T., Morton, O., 2009, Late Pleistocene-Holocene geochemical history inferred from Lake Tecocomulco sediments, Basin of Mexico, Mexico: Geochemical Journal, 43, 49-64.

Ruiz-Picos, R., López-López, E., 2012, Gill and liver histopathology in Goodea atripinnis Jordan, related to oxidative stress in Yuriria Lake, Mexico: International Journal of Morphology, 30(3), 1139-1149.

Sánchez-Santillán, N., Guzmán Ruíz, S., SánchezTrejo, R., Ritter-Ortíz, W., Lázaro-Chávez, M.E., 2004, La influencia de la oscilación de la temperatura del aire sobre el ecosistema de la Presa de Atlangatepec, Tlaxcala, México: Hidrobiologica, 14(1), 75-84.

Sarma, S.S., Elías-Gutiérrez, M., Serranía-Soto, C., 1996, Rotifers from high altitude craterlakes at Nevado de Toluca Volcano, México: Hidrobiologica, 6, 33-38.

Serra-Puche, M.C., 1988, Los recursos lacustres de la Cuenca de México durante el Formativo: Distrito Federal, Universidad Nacional Autónoma de México, Coordinación General de Estudios de Posgrado, 270 p.

Servicio Meteorológico Nacional (SMN), 2015, Normales Climatológicas (online): Ciudad de Méxic, SMN, published/updated 2010, available at <http://smn.cna.gob.mx/ 
emas/>, downloaded September 5, 2015.

Sinev, A.Y., Zawisza, E., 2013, Comments on cladocerans of crater lakes of the Nevado de Toluca Volcano (Central Mexico), with the description of a new species, Alona manueli sp. n.: Zootaxa, 3647(2), 390-400.

Torres-Rodríguez, E., Lozano-García, S., Figueroa-Rangel, B.L., Ortega-Guerrero, B., Vázquez-Castro, G., 2012, Cambio ambiental y respuestas de la vegetación de los últimos 17000 años en el centro de México: el registro del lago de Zirahuén: Revista Mexicana de Ciencias Geológicas, 29(3), 764-778.

Trejo-Albarrán, R., Granados-Ramírez, J.G., Gómez-Márquez, J.L., Peña-Mendoza, B., Bonilla-Barbosa, J.R., 2014, Variación del cladócero Daphnia laevis Birge, 1879 en el Lago Zempoala, Morelos, México: Mesoamericana, 18(1), 25-38.

Vázquez, G., Favila, M., 1998, Status of the health conditions of subtropical Atezca Lake: Aquatic Ecosystem Health \& Management, 1, 245-255.
Vázquez-Rodríguez, G.A., Beltrán-Hernández, R.I., Lucho-Constantino, C.A., Blasco, J.L., 2008, A method for measuring the anoxic biodegradability under denitrifying conditions: Chemosphere, 71, 1363-1368.

Vilaclara, G., Chavez, M., Lugo, A., Gonzalez, H., Gaytan, M., 1993. Comparative Description of Crater-Lakes Basic Chemistry in Puebla-State, Mexico: Verhandlungen des Internationalen Verein Limnologie, 25, 435-440.

Wetzel, R.G., Likens, G.E., 1991, Limnological Analyses: New York, Springer-Verlag, 391 p.

Xia, X., Wu, Q., Zhu, B., Zhao, P., Zhang, S., Yang, L., 2015, Analyzing the contribution of climate change to long-term variations in sediment nitrogen sources for reservoirs/ lakes: Science of the Total Environment, 523, 64-73.

Xu,J., Ho, A.Y., Yin, K., Yuan, X., Anderson, D.M., Lee, J.H., Harrison, P.J., 2008, Temporal and spatial variations in nutrient stoichiometry and regulation of phytoplankton biomass in Hong Kong waters: influence of the Pearl River outflow and sewage inputs: Marine Pollution Bulletin, 57, 335-348. 

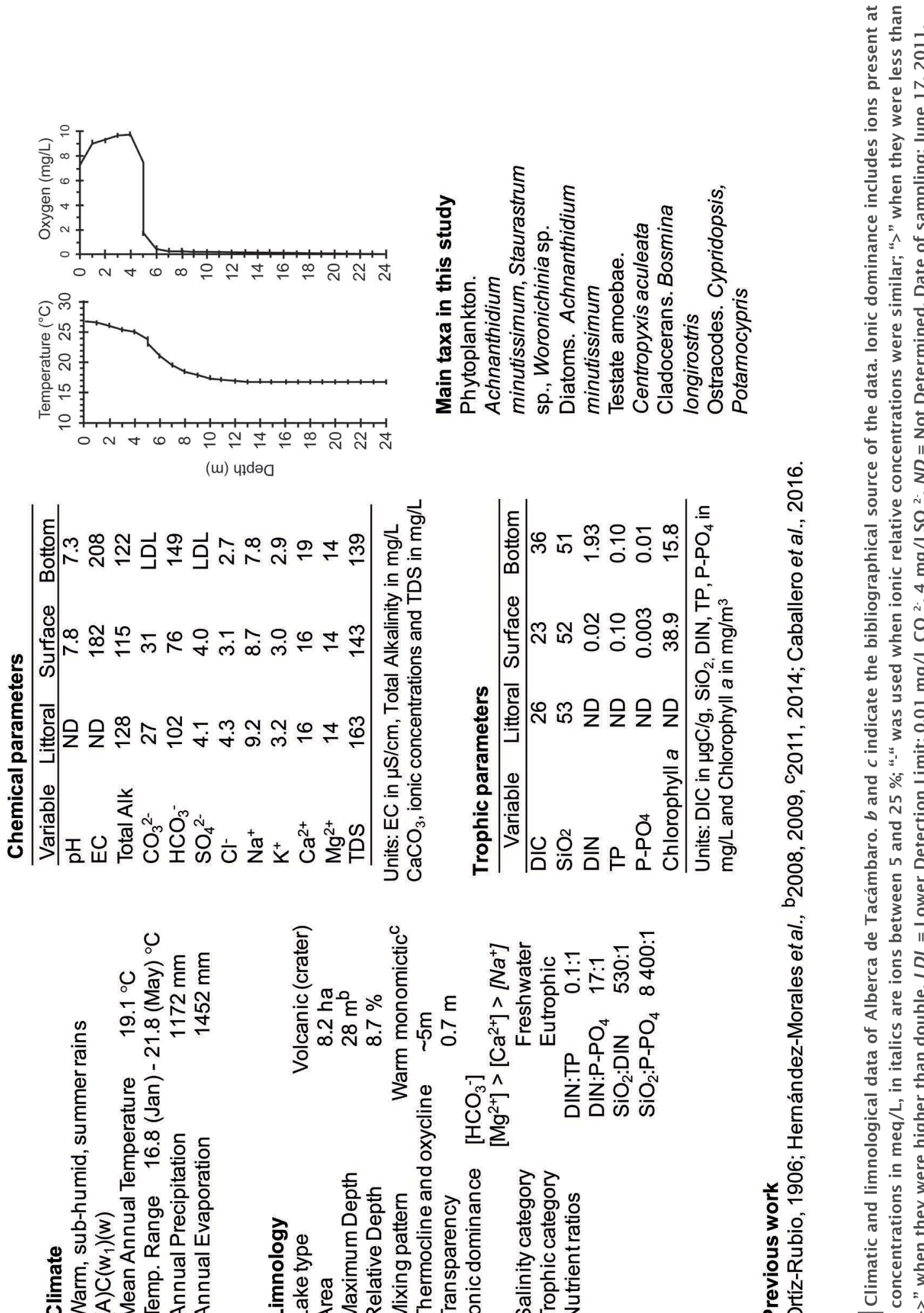

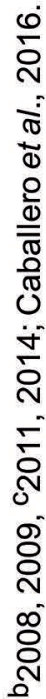
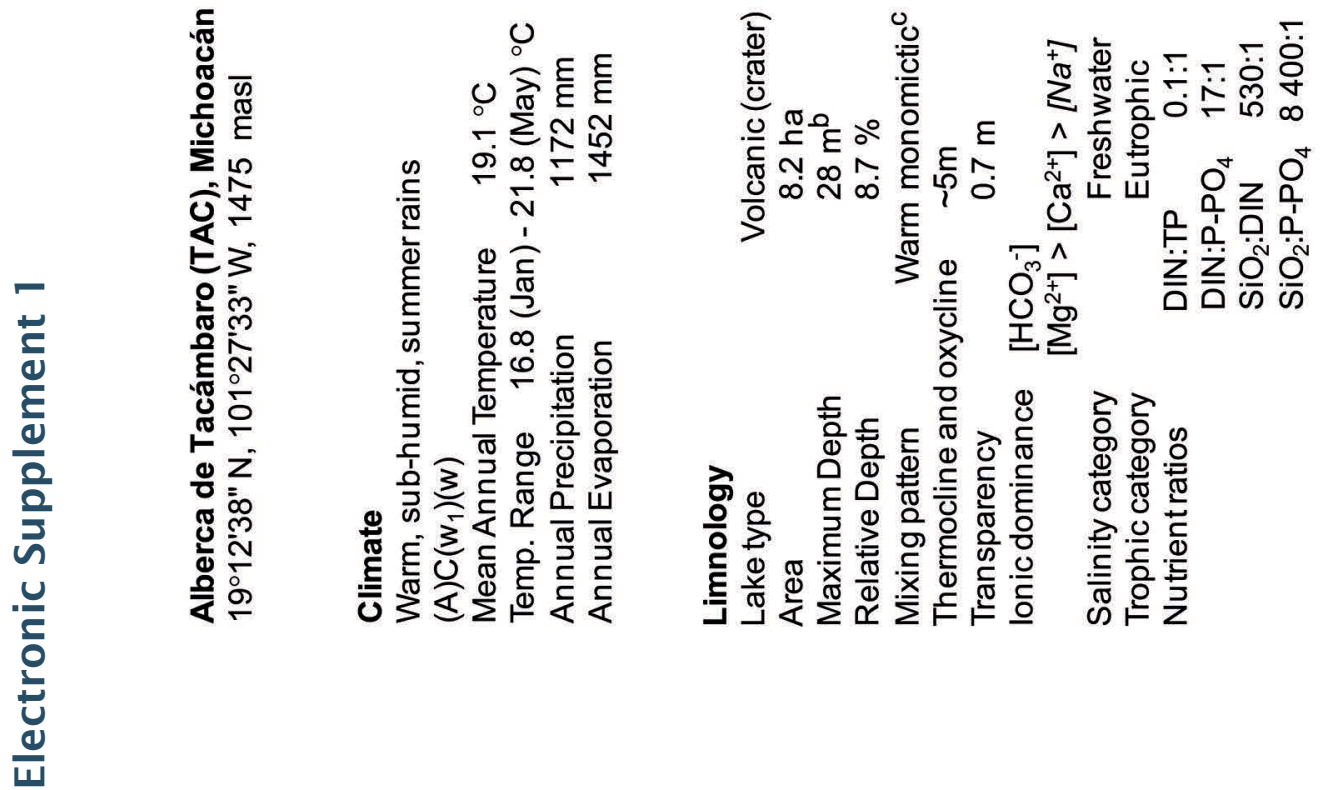

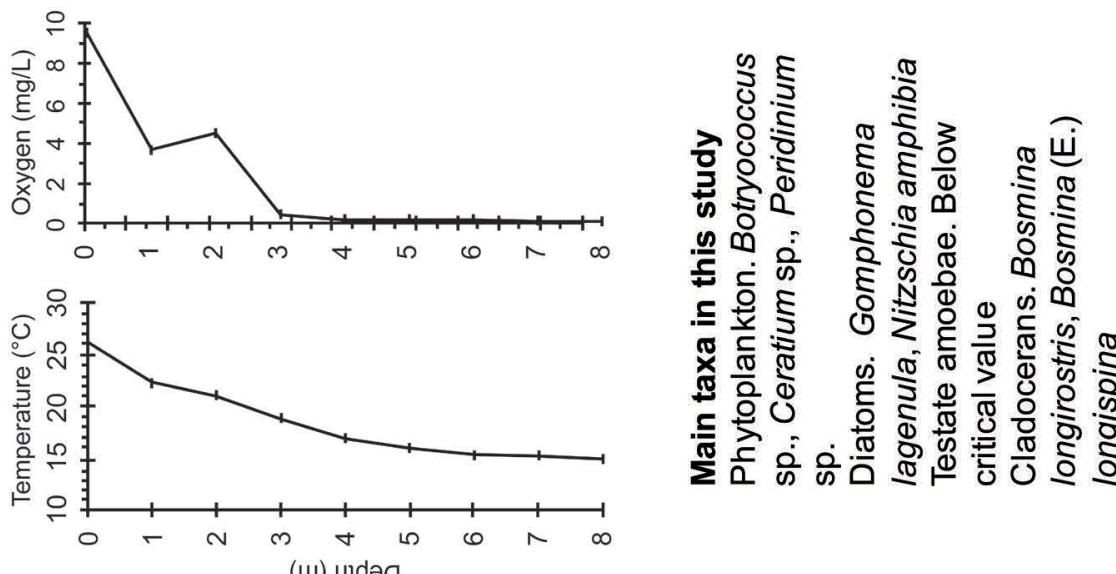

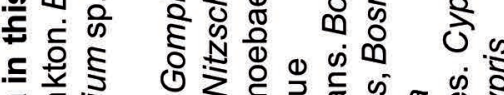

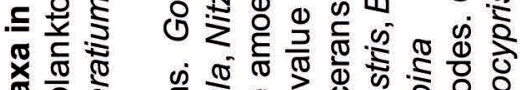
응

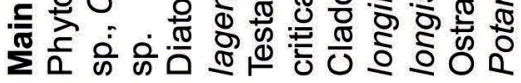
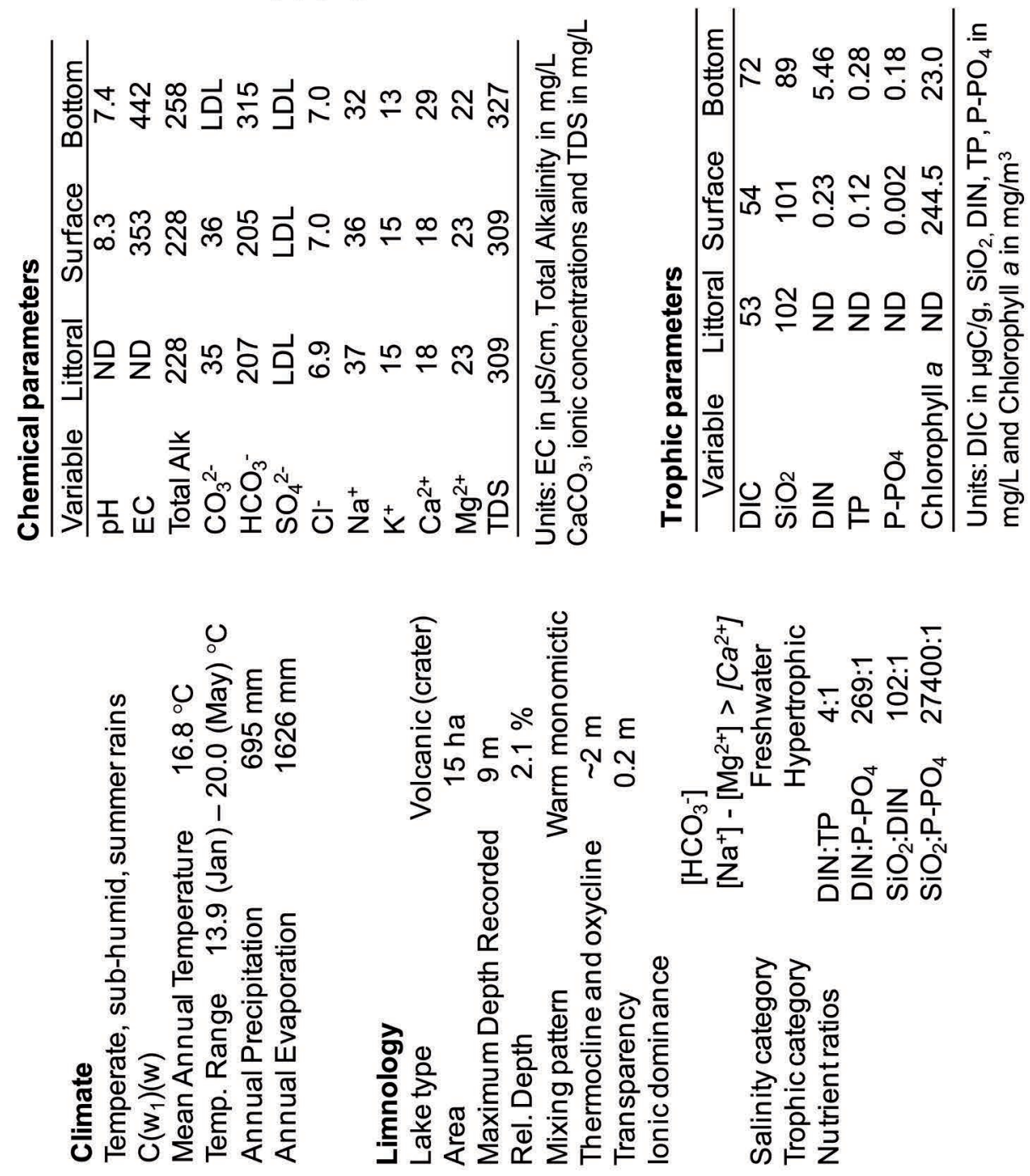

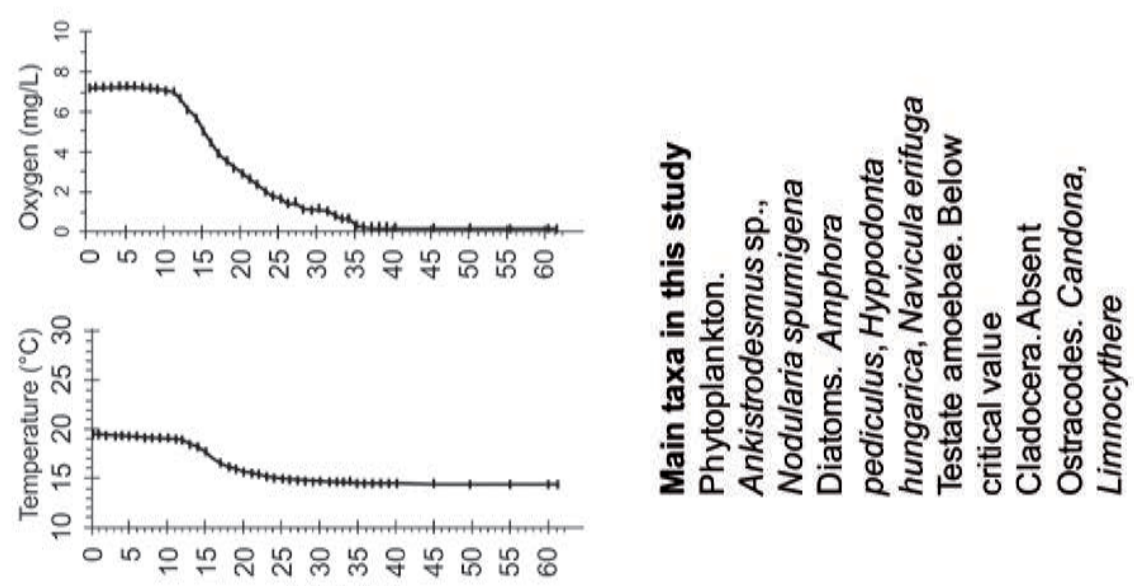

ठ்

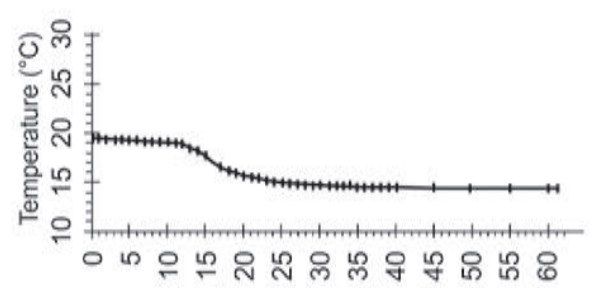

(ui) प1d dəa
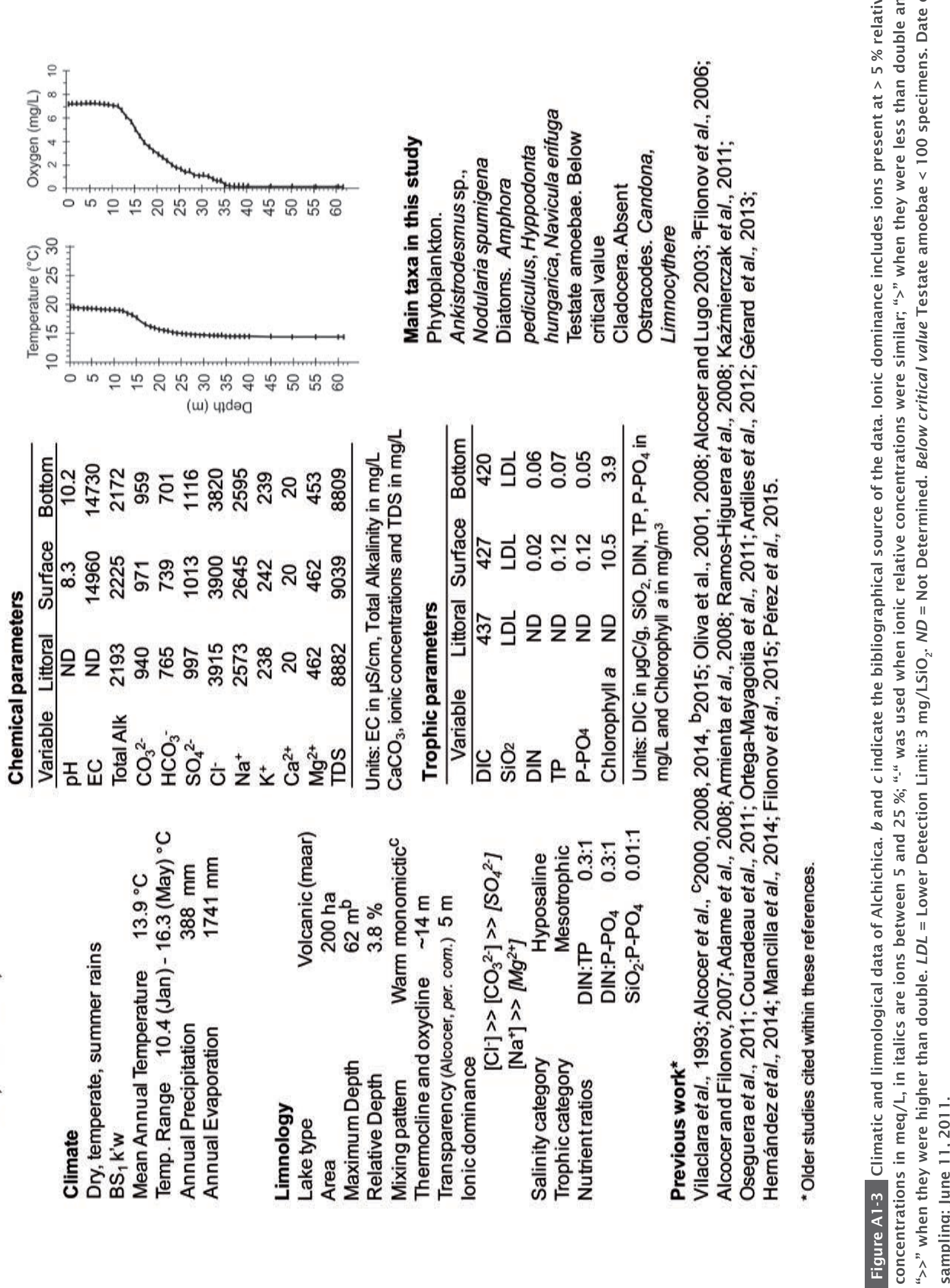

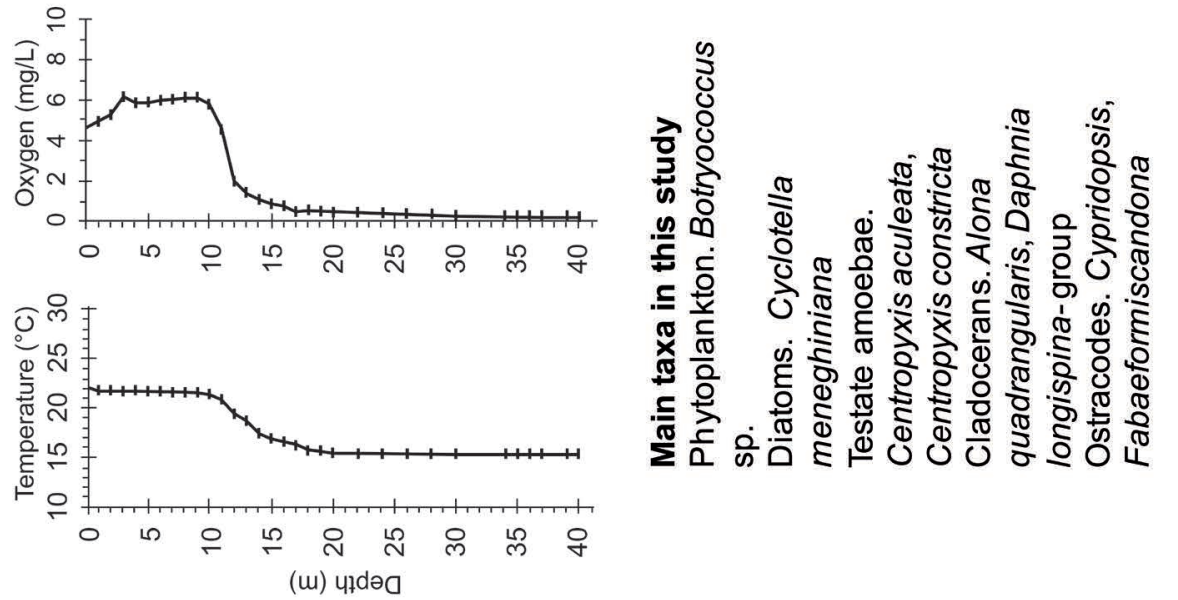

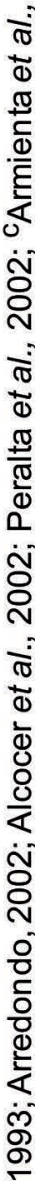
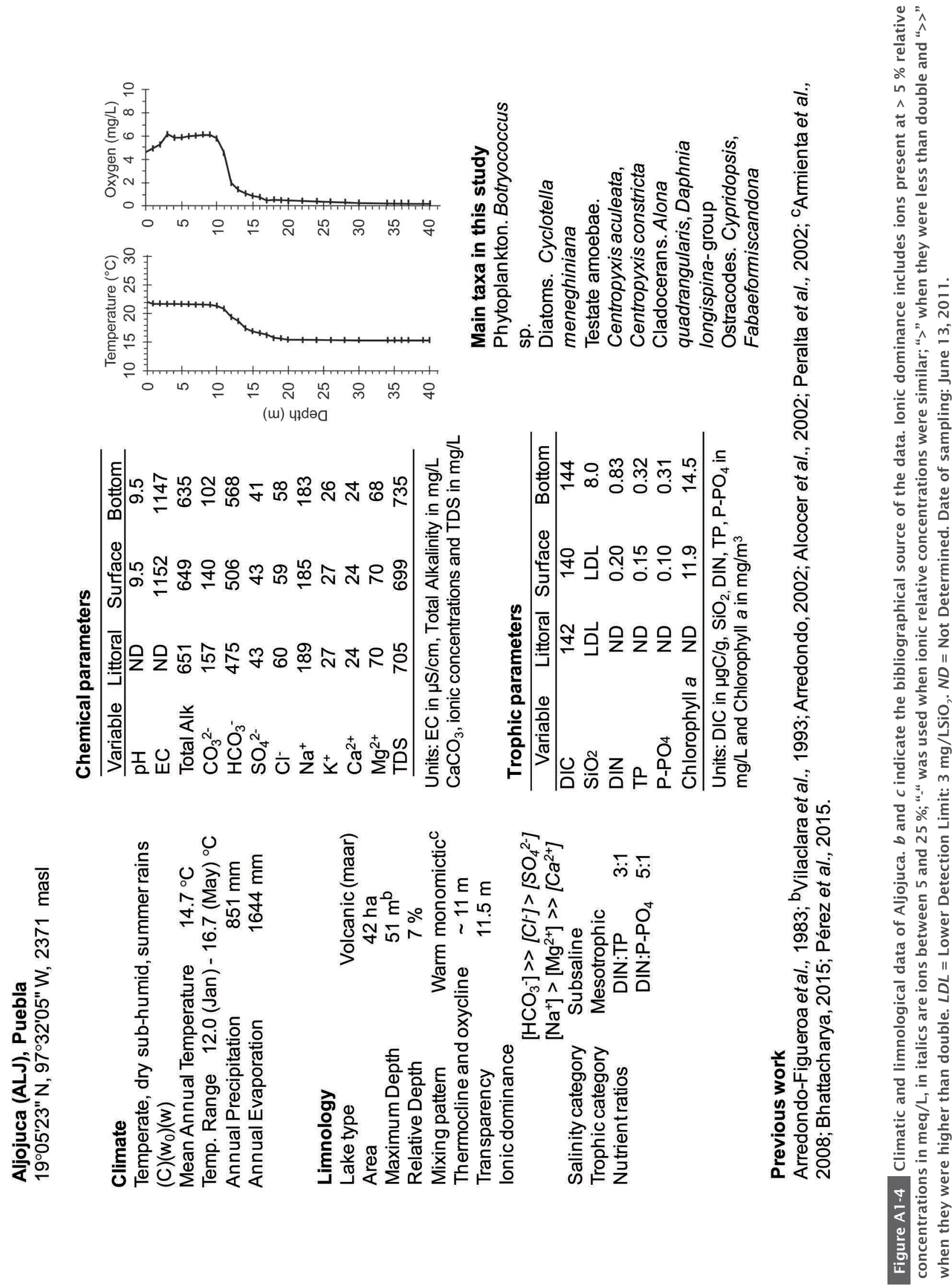

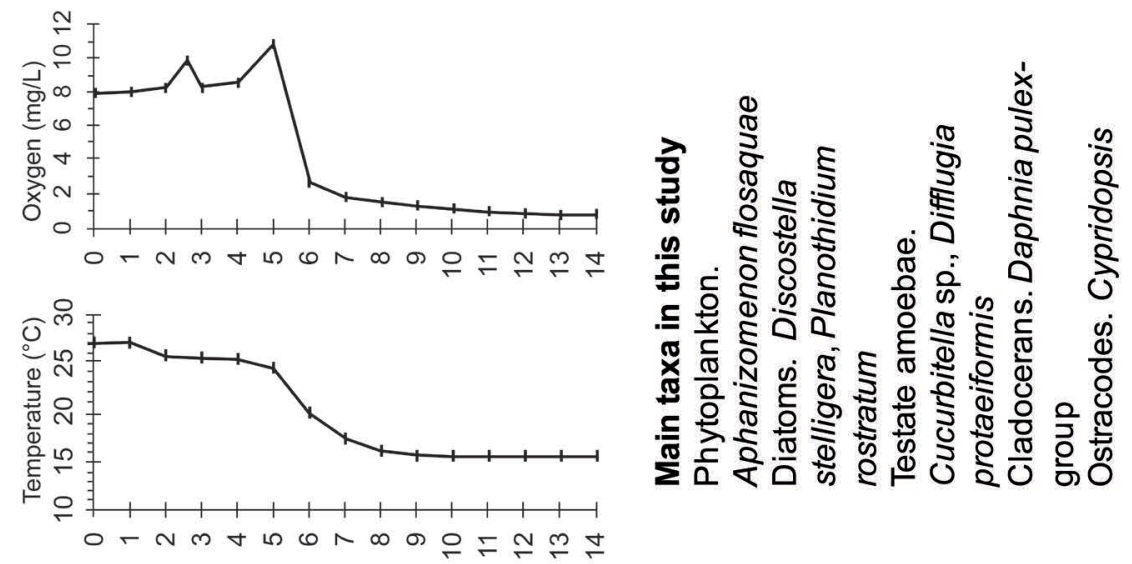

(u) 47 də0
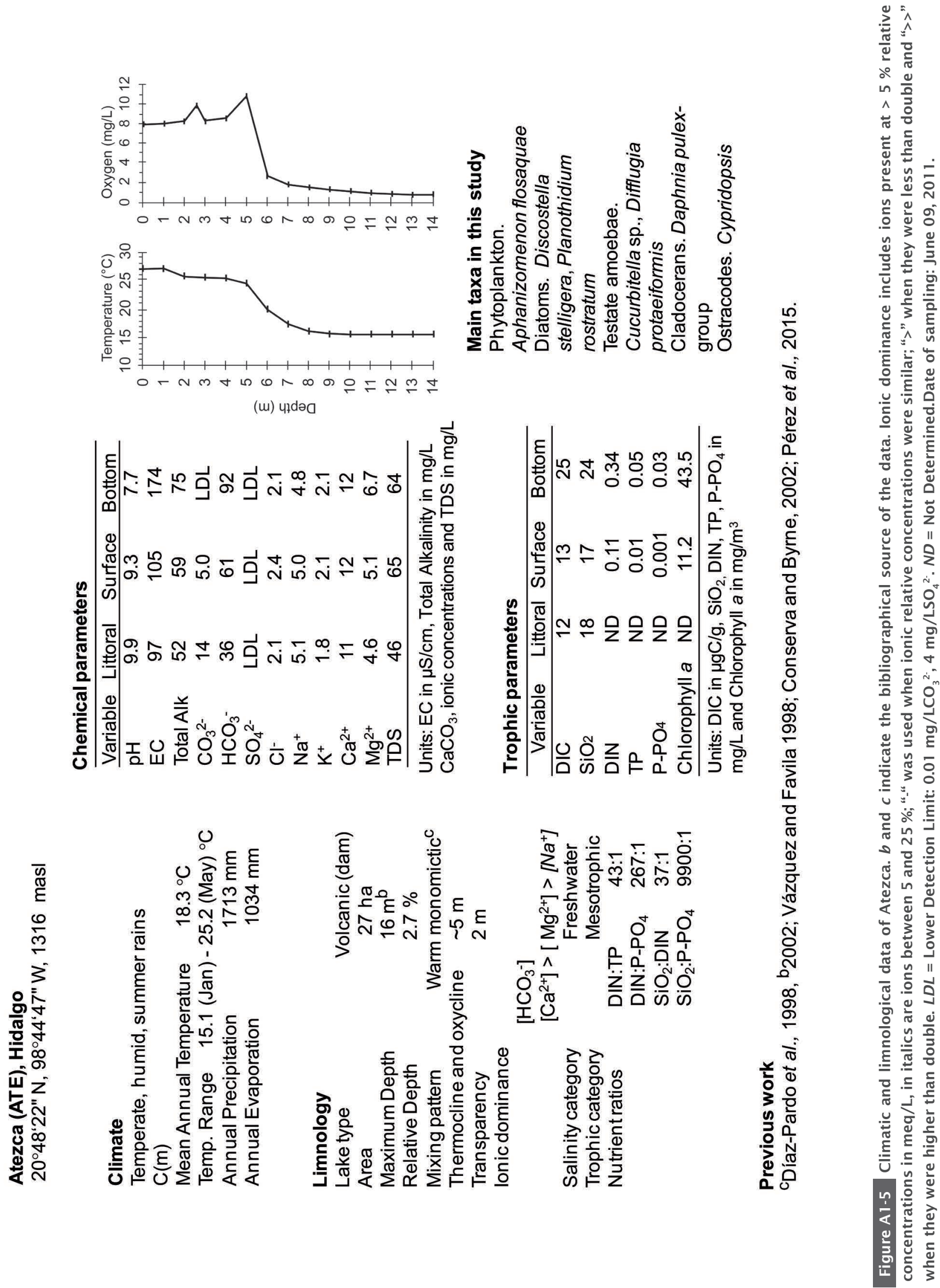

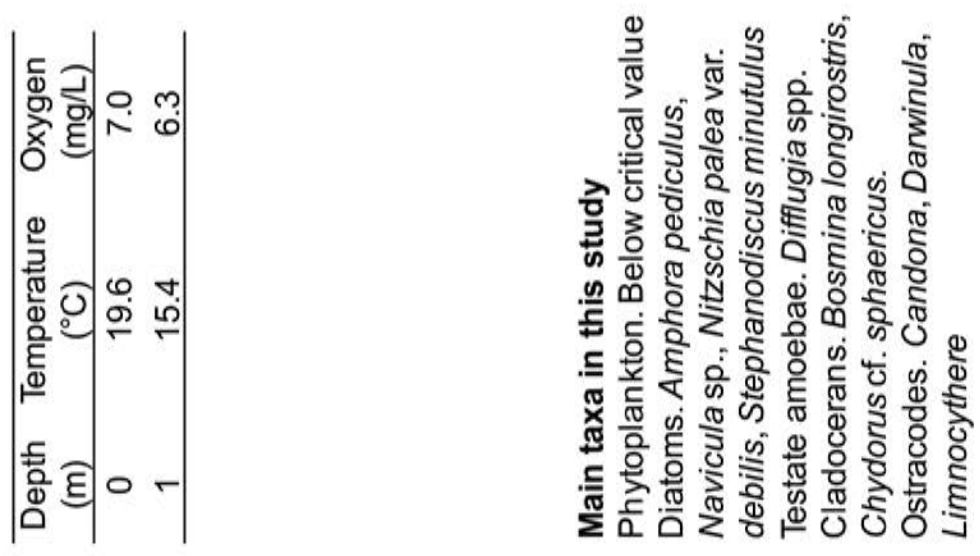

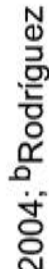
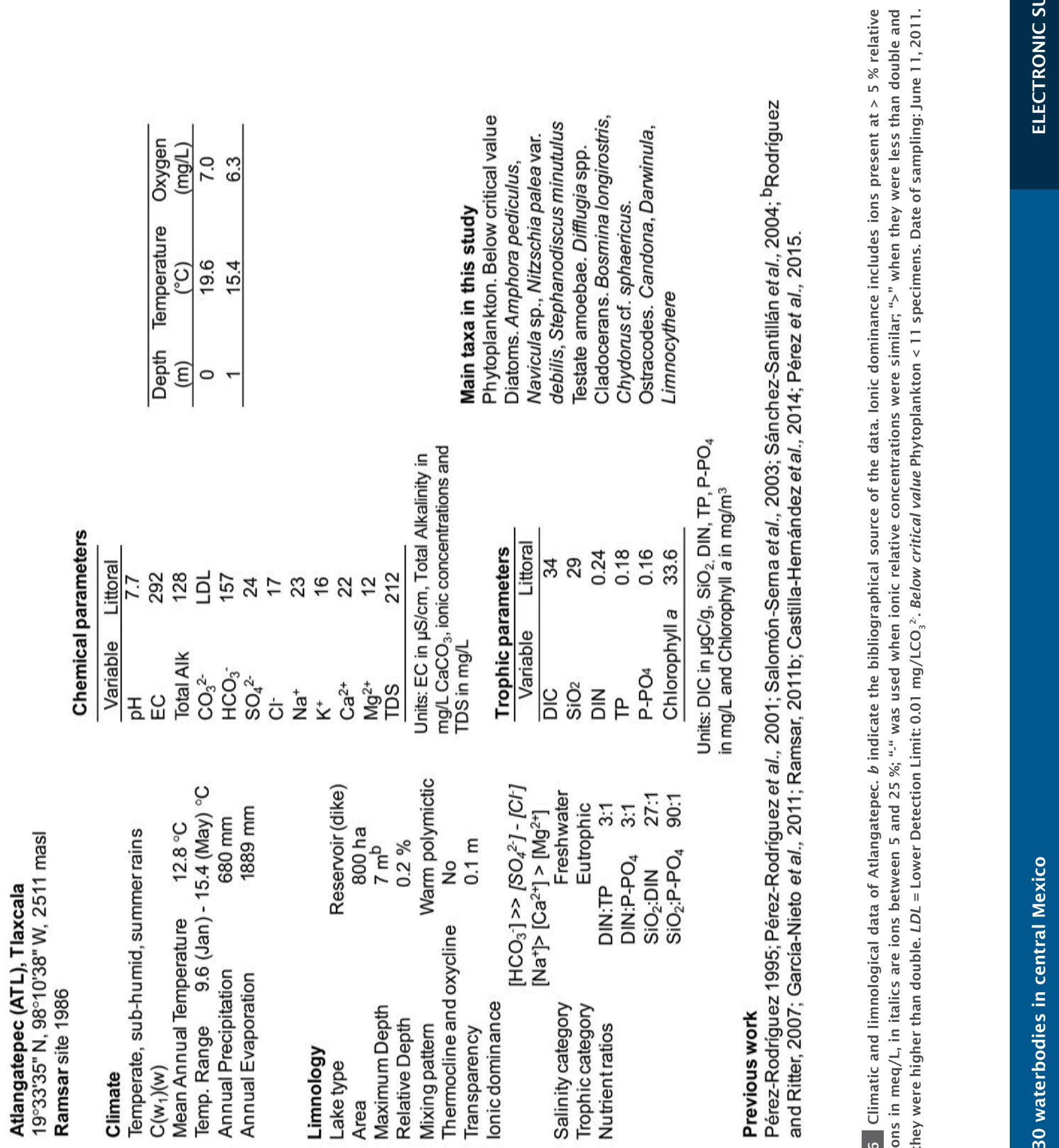

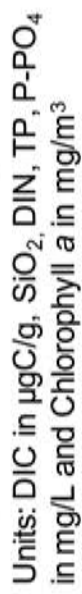

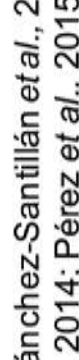

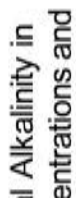

का

กั ब

웜

तิ $\cdot \frac{\mathrm{C}}{\mathrm{C}}$

๘

E $T$

क禹

हั

लำ

密参

政

ज

을

要

$\stackrel{\Xi}{3}$

जै

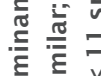

흠

苇

खु

范

을

प०

ช 0

譪

ฮู ญ

党

응 뒁

जे के



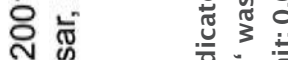

तें हो

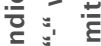

$\rightarrow$ จั

ธำ

츄유

능 तั

ㄸำ

인워

西

กิ $\frac{\pi}{0}$

क ํำ

N

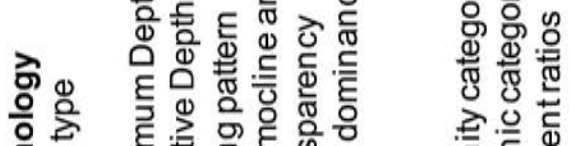

3 능

밈

을 ⿺ 뭉

ฮัญ 

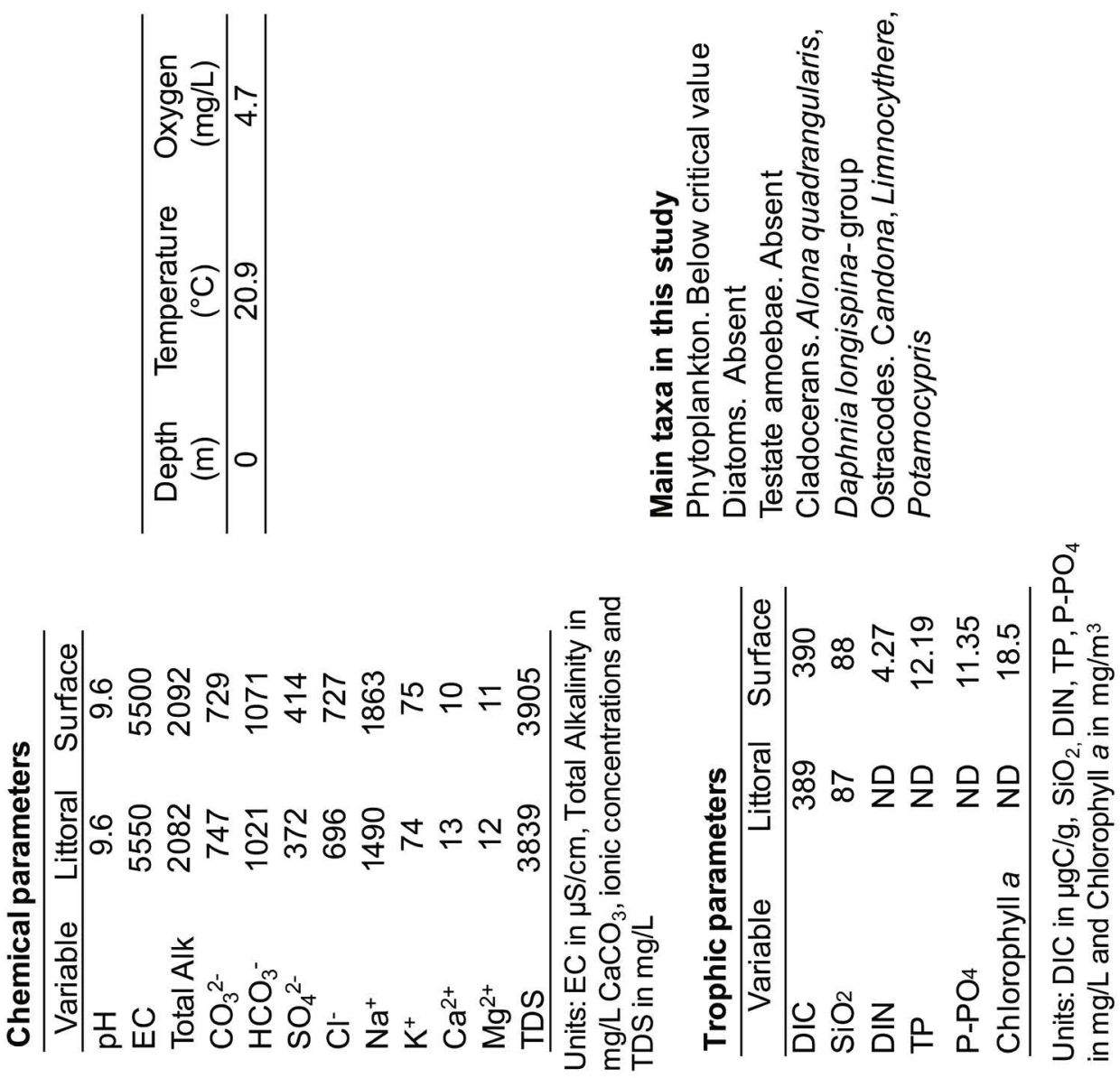

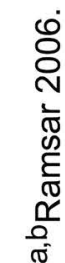
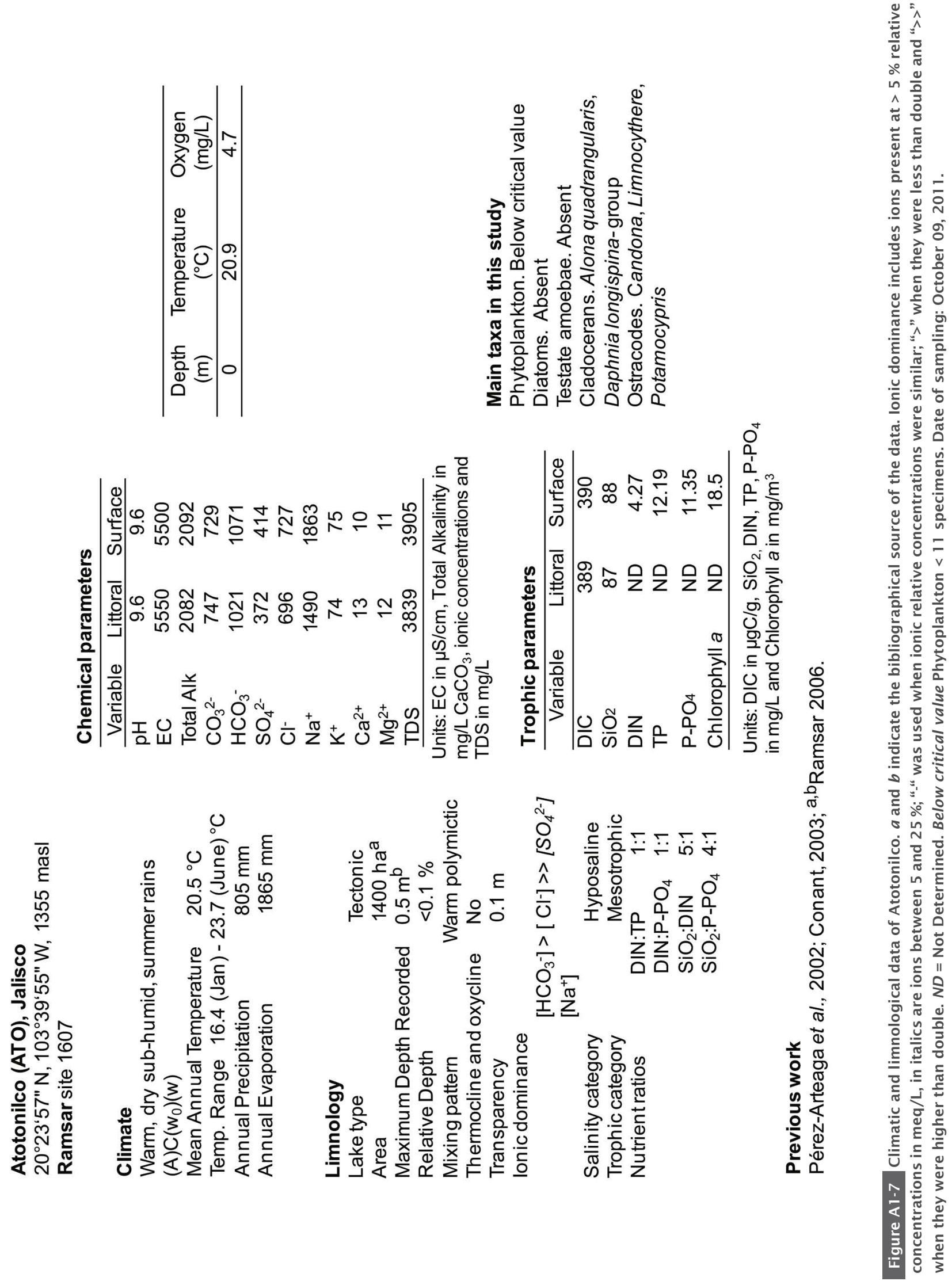

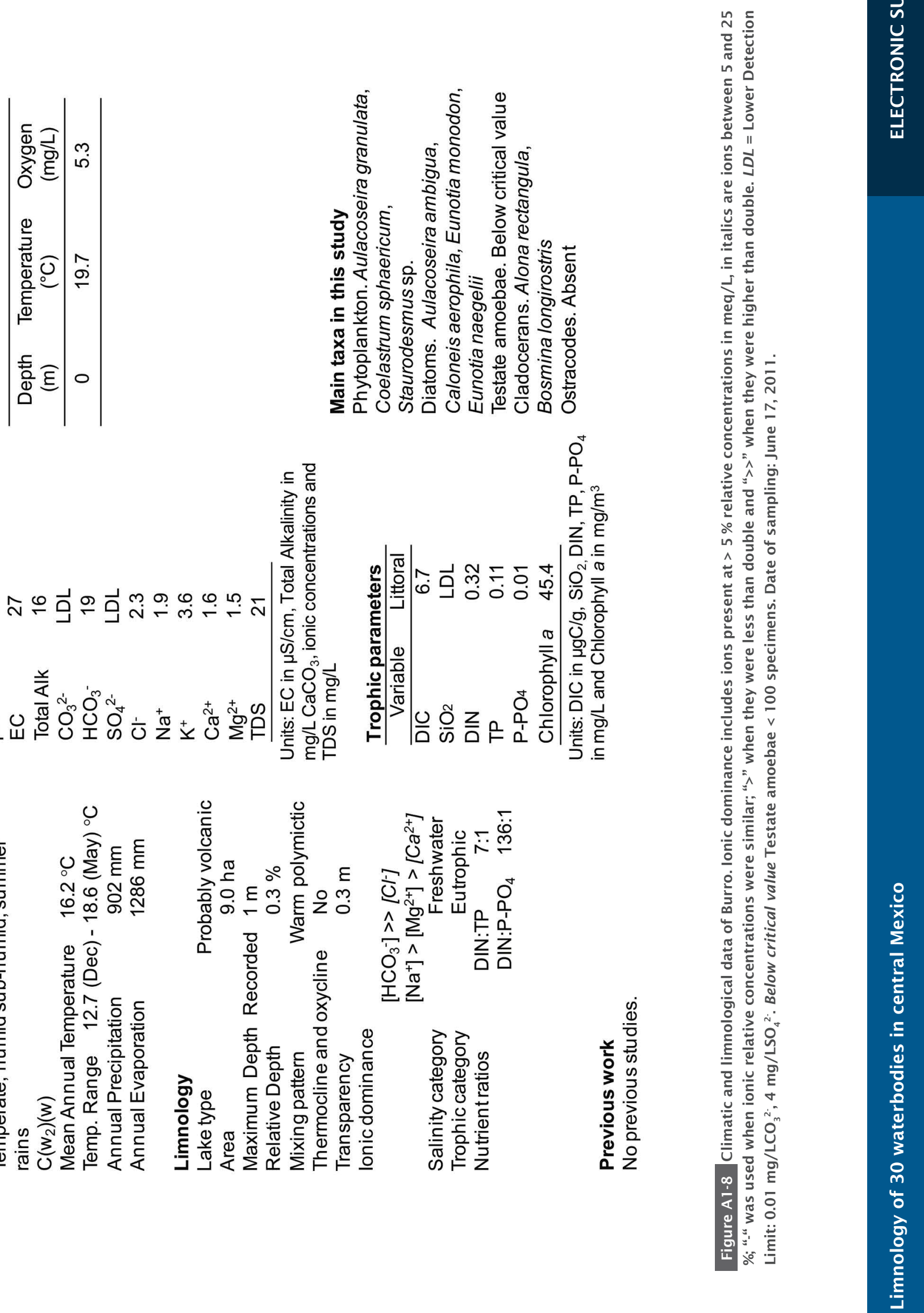

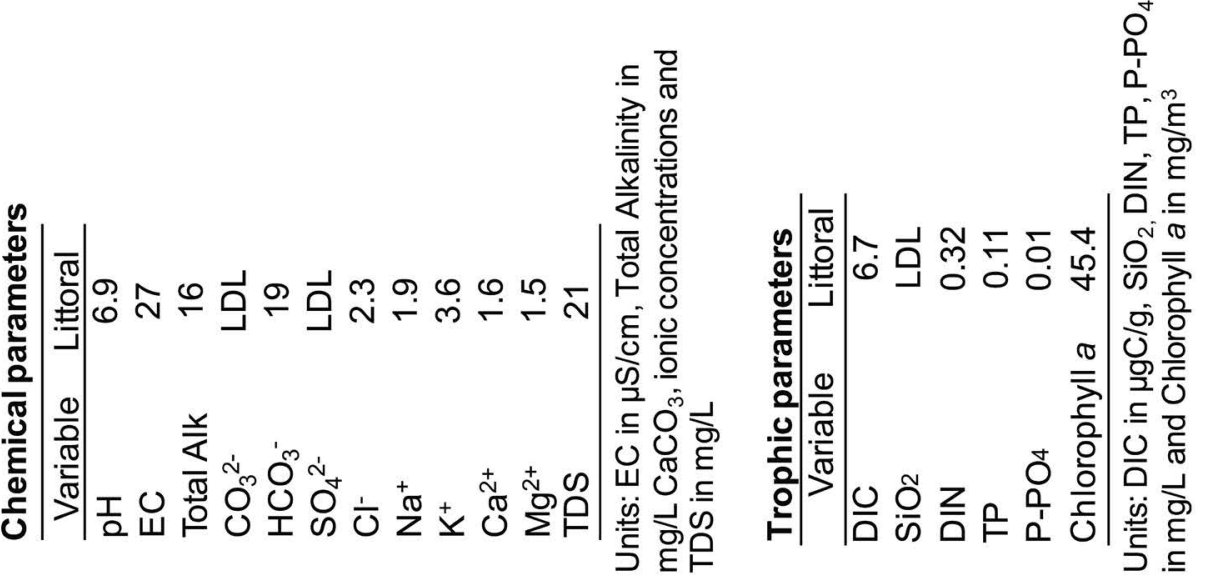

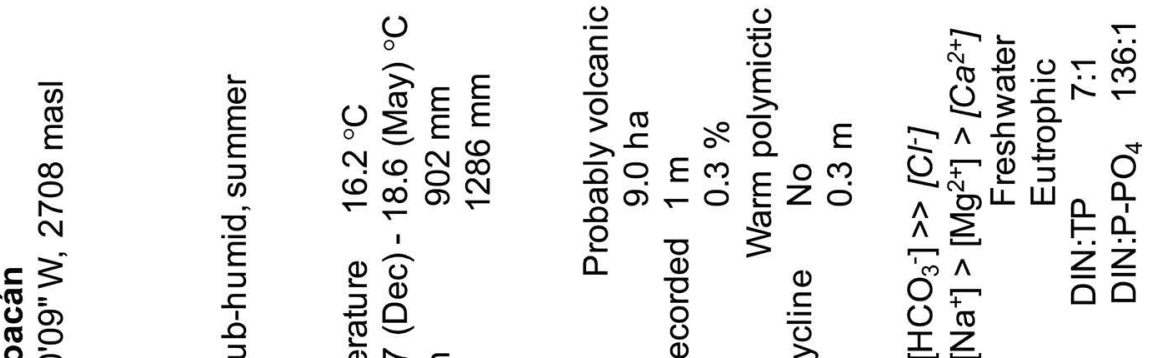

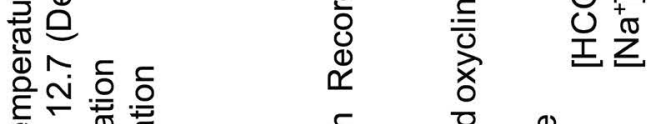

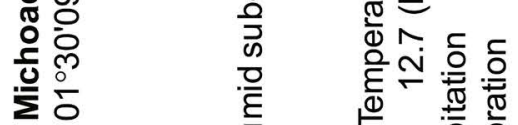

金艺

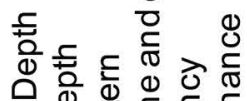
즌

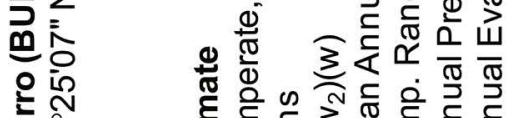

商

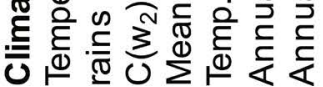

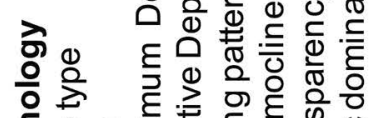

है

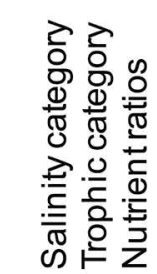

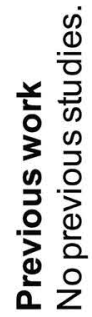



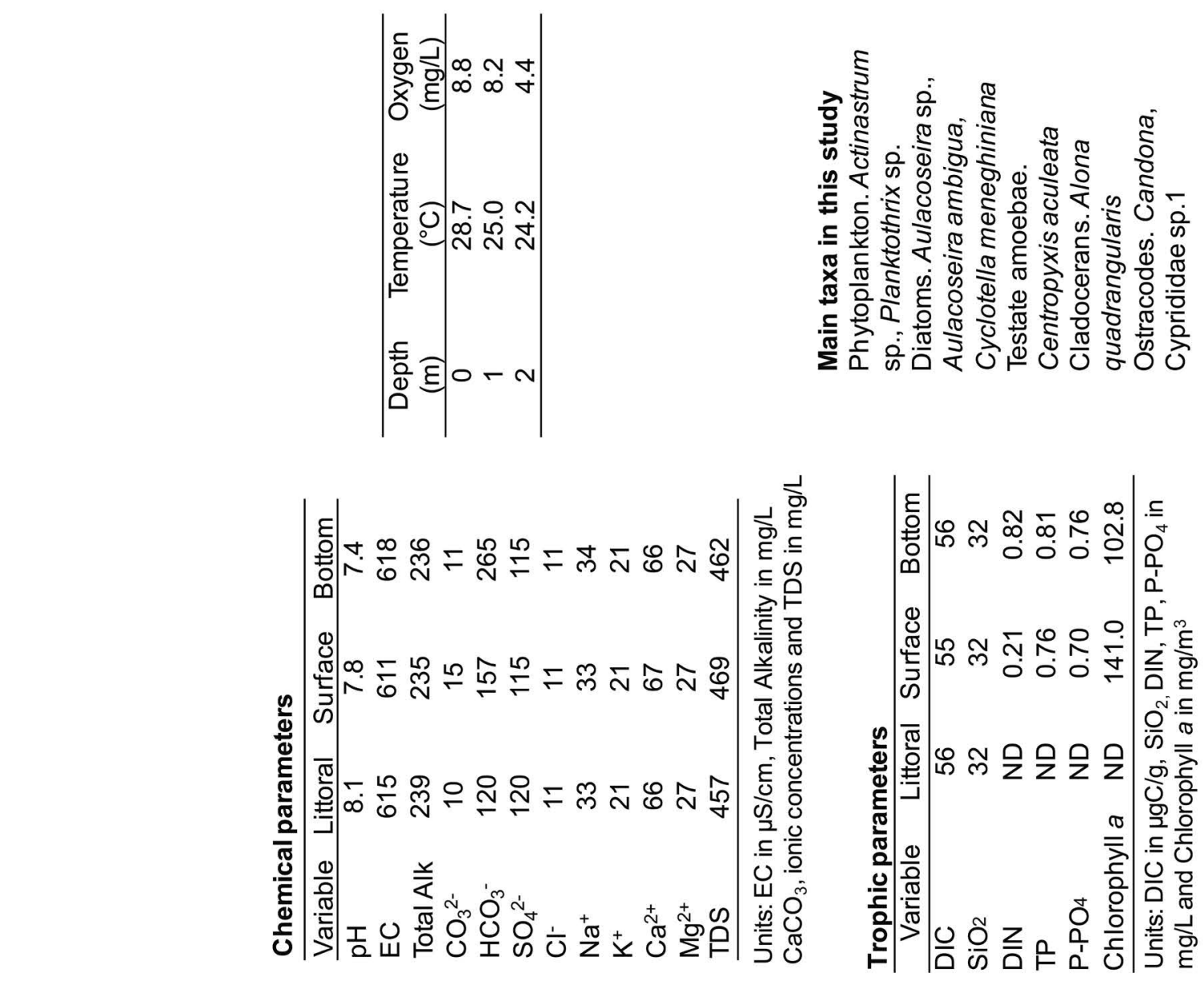

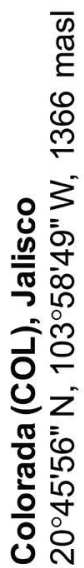

ن $\stackrel{0}{\stackrel{0}{\triangle} \varepsilon \varepsilon}$

ำ

乐品
ก

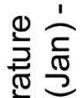

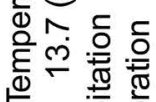

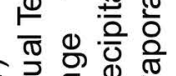

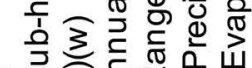

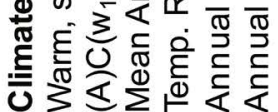

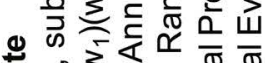

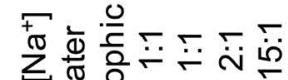

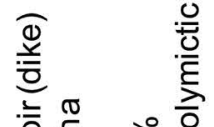

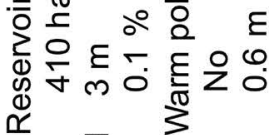

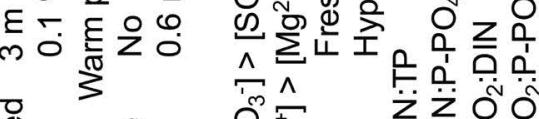

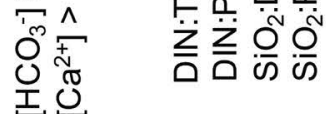

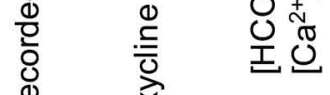
\.

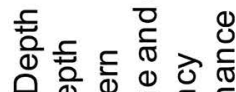

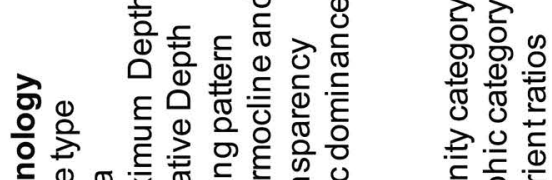

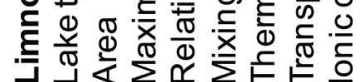
글은 둥 œั 


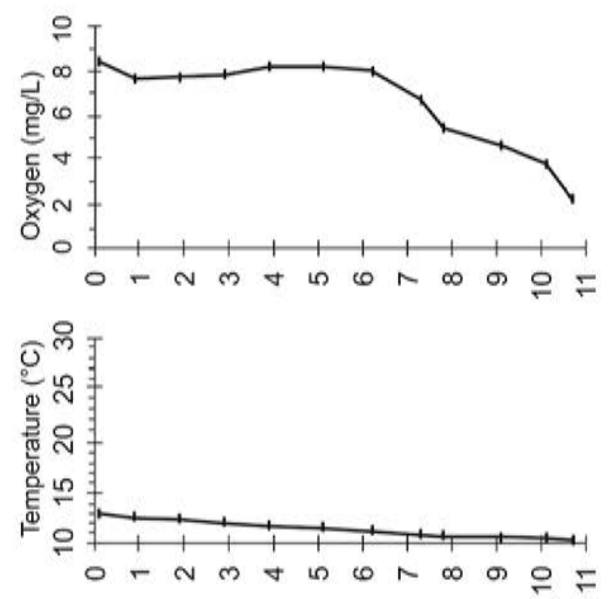

(w) पा dəo
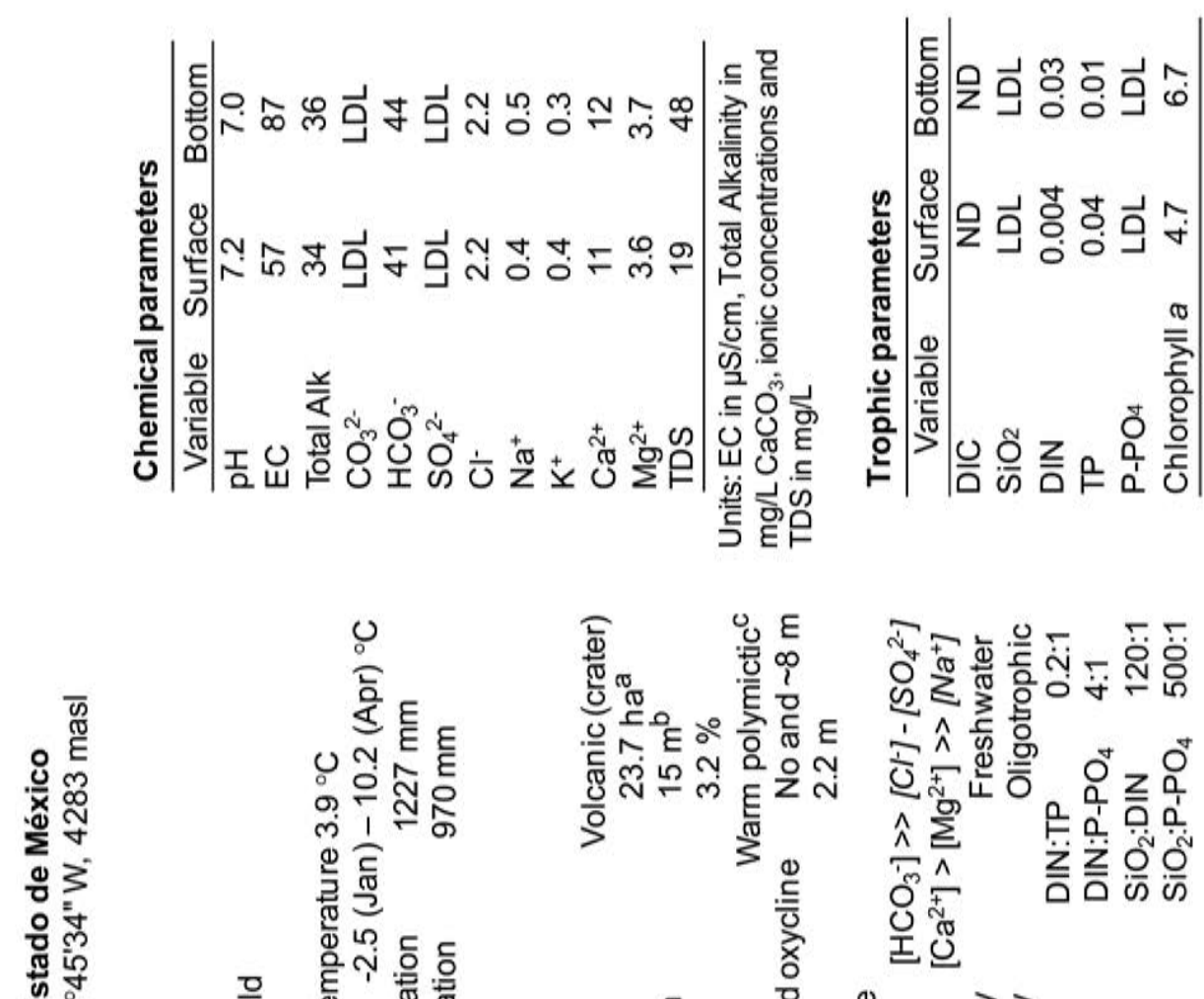

แั

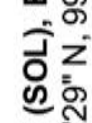

我品
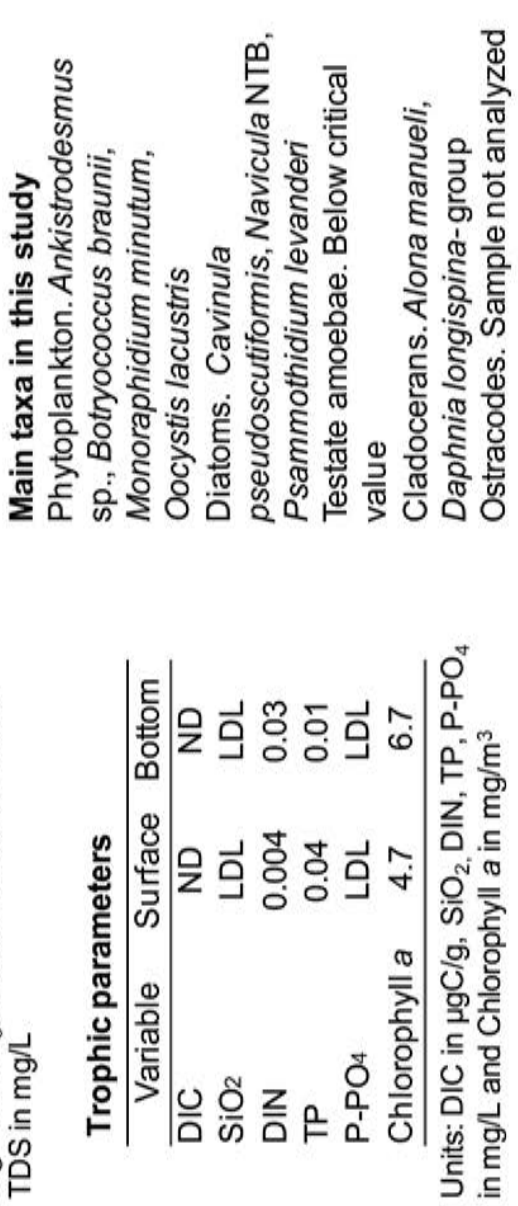

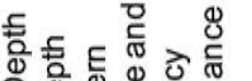

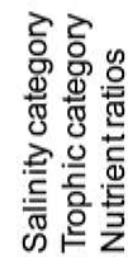

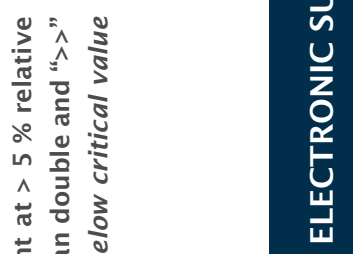

둥

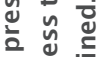

등 है

ป 3

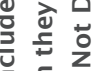

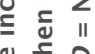

造这

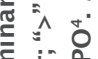

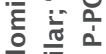

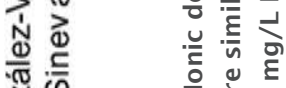

N

ㄷํㅇ ㅇํㅇ

ำ

คे ฌ்

ㄷำ

तो

뜐 은

के के

(당 है

등

๓ึ

ต் 유

बำ

ธิ่

屯

हृ $\frac{\mathscr{\Phi}}{E}$

ल

ஸ் ல்

ब유

은

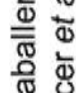

过

Бำ

बำ

능 총

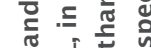

แ

은 윰

む亡 

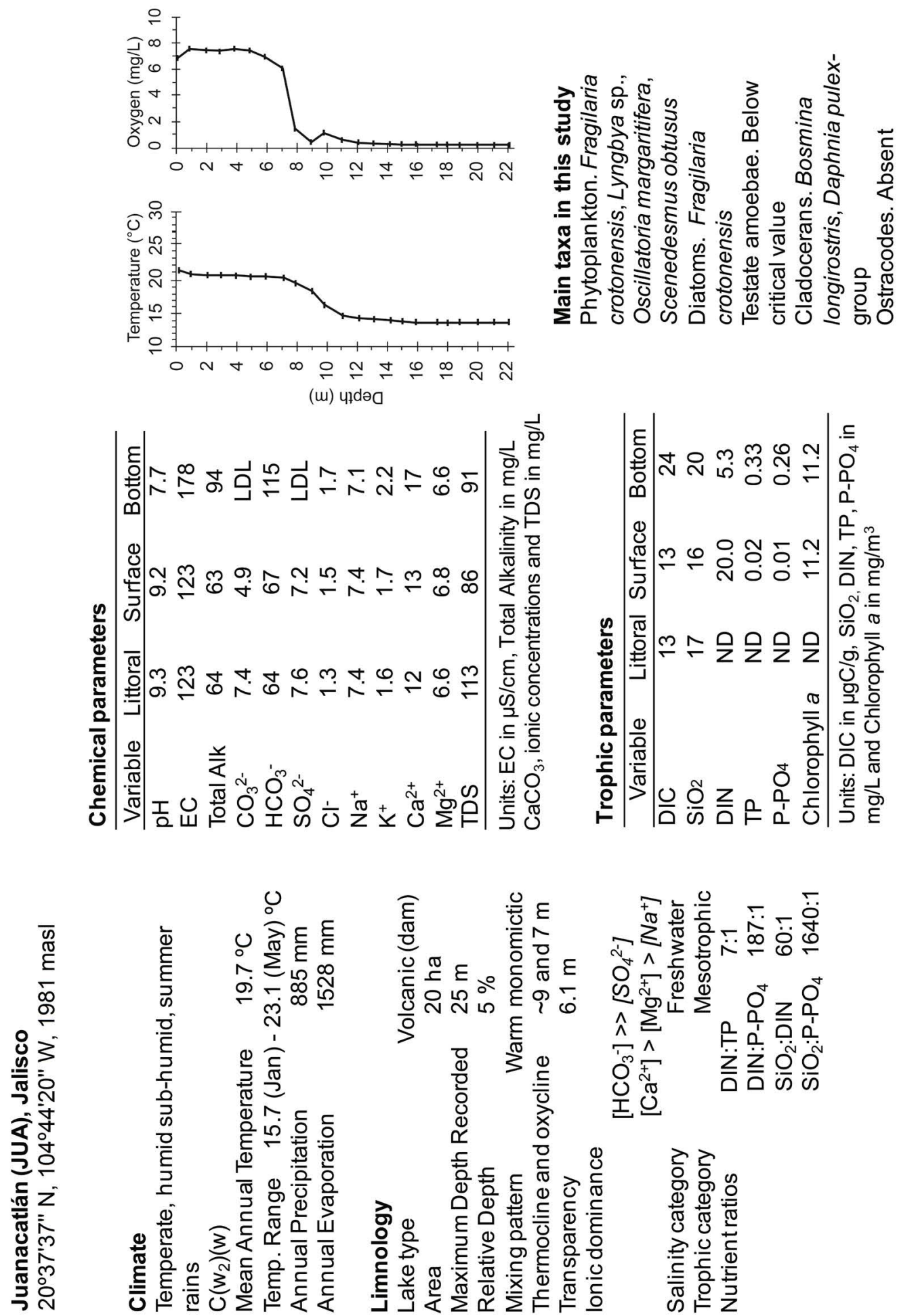

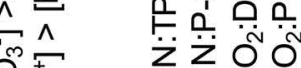

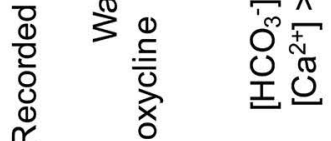

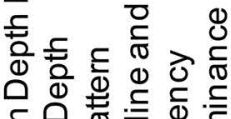
하응 잉

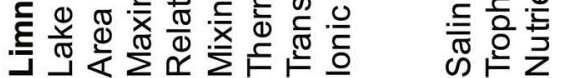

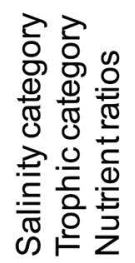



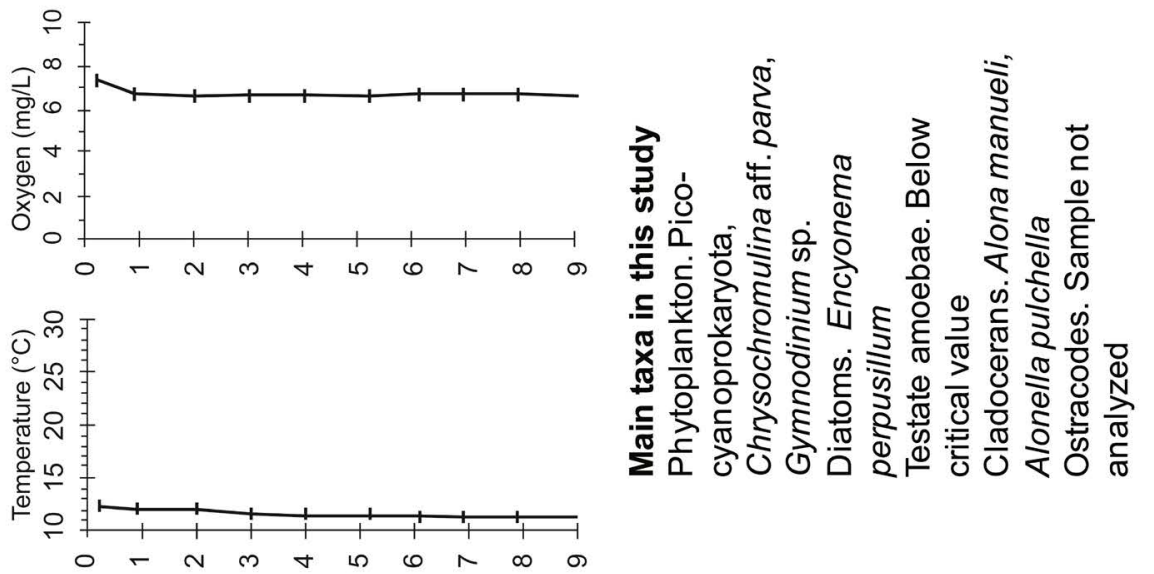

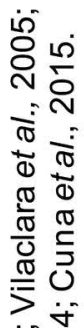

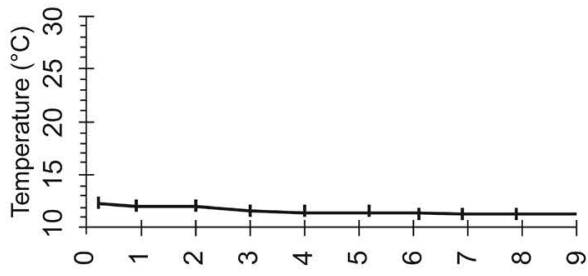

$\sum_{i=1}^{n}$

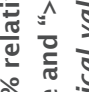

in 응

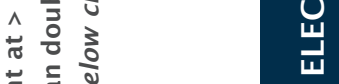

(u) प1 $\mathrm{d} ә$

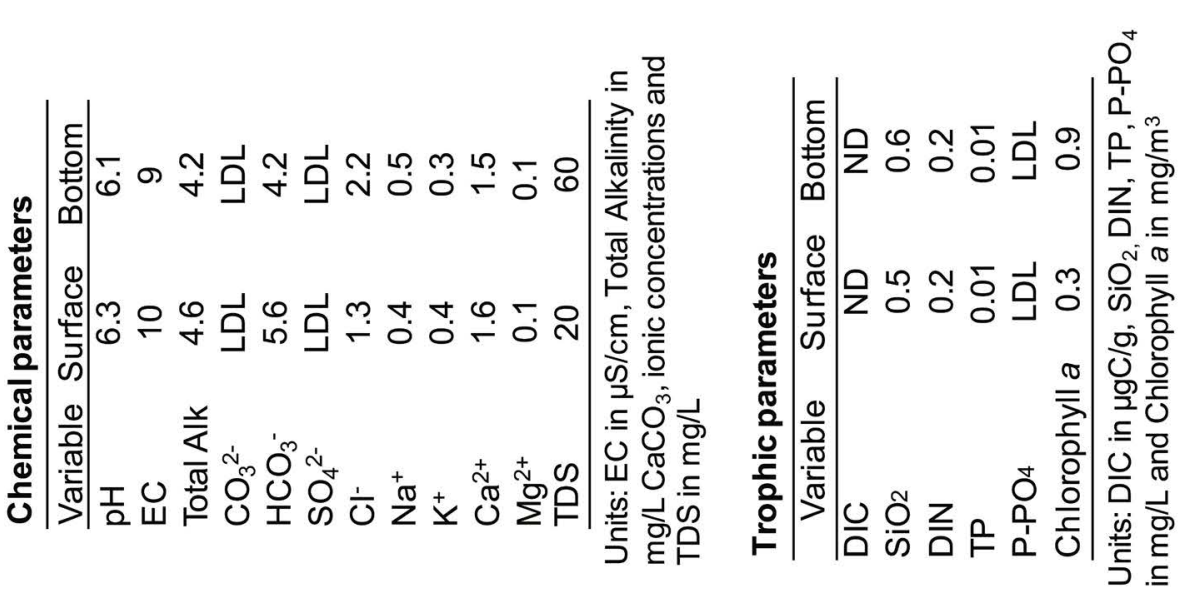

N.

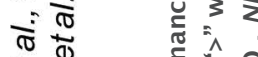

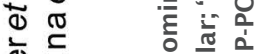

ठ্ำ

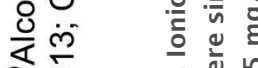

○ ग

สิก

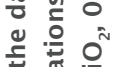

D

衣离

屯ळ छั है

\& ठ

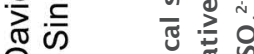

Qิن

ठํㅇ है

ㄴ. 하

交范

ป

$N$

$\stackrel{\square}{\circ}$

ชั

$\sum^{\pi} N \quad \Xi 30$

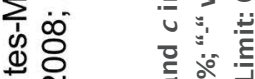

에

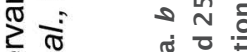

ปั

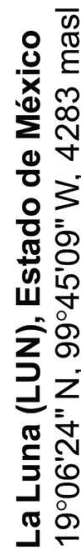

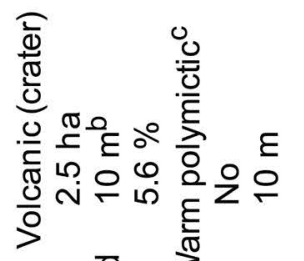

ডั $1 \leqslant 3$

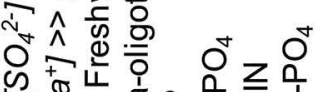

लं ํํำ

อ $\frac{1}{\frac{1}{5}}$

귱

ํํㄹ 눈 으

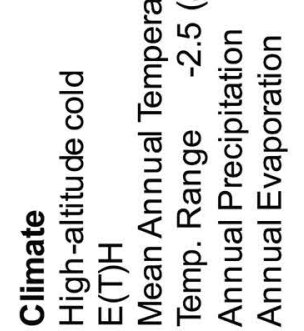

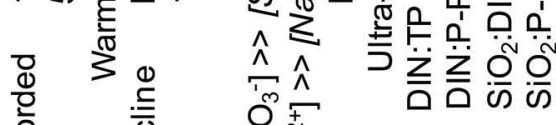

O্ ฯ

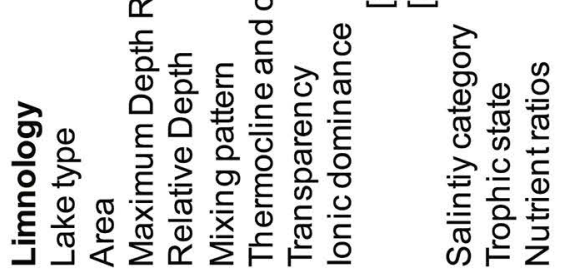

0 \%

용 음

은 흔

के

屯.

중

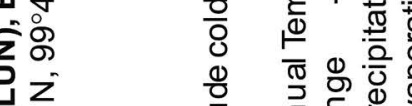

हैं

ผ 응

영

은 엉

号迹要

은

ة 

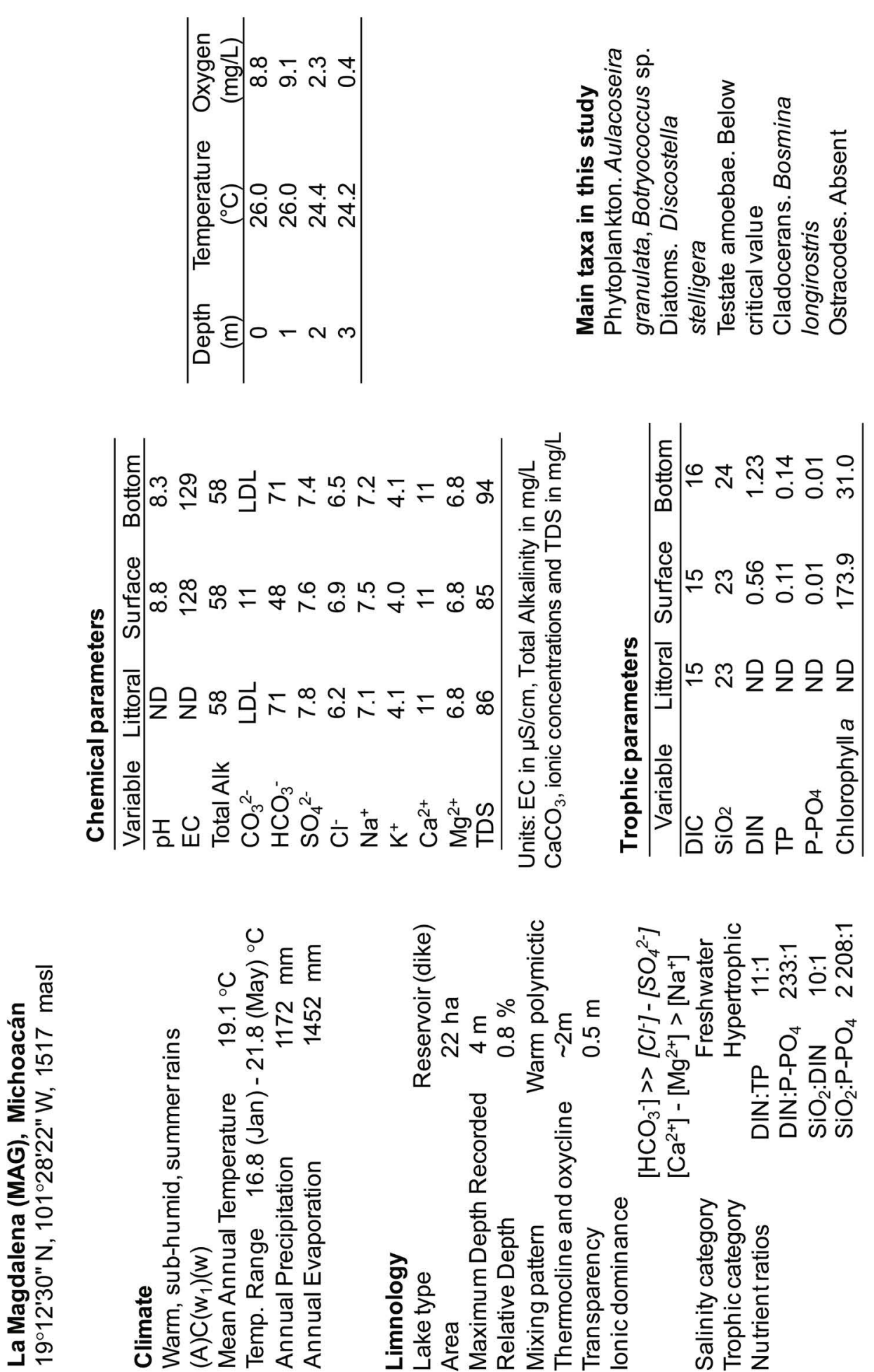

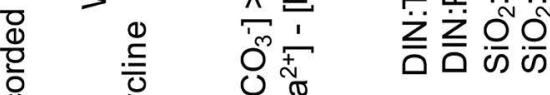

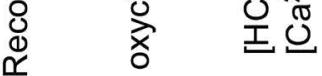

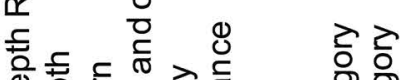

这言舫

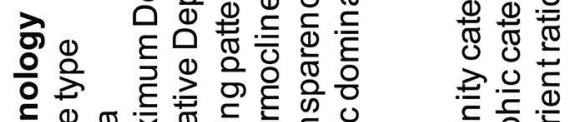

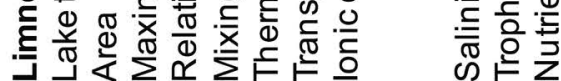

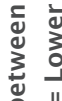



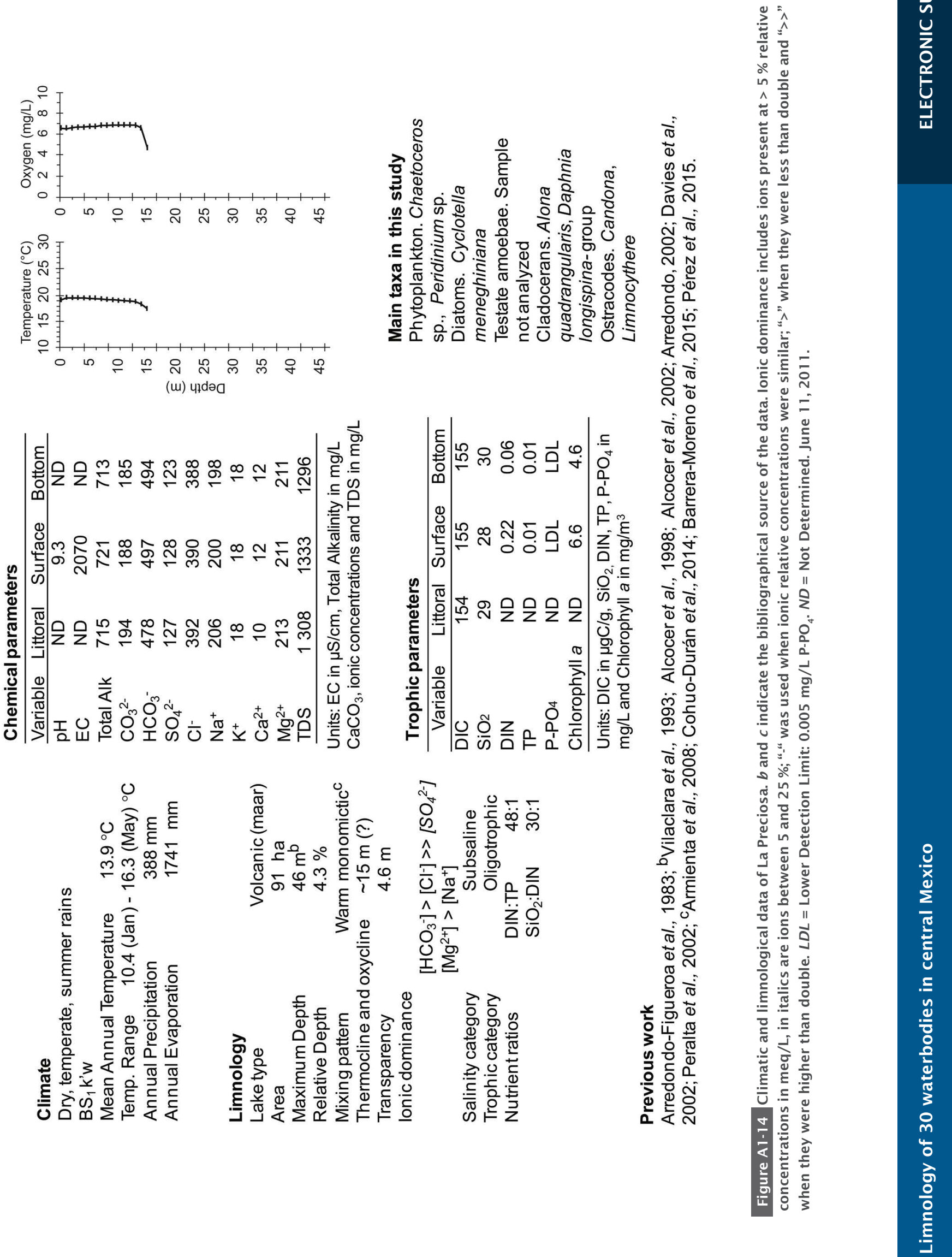

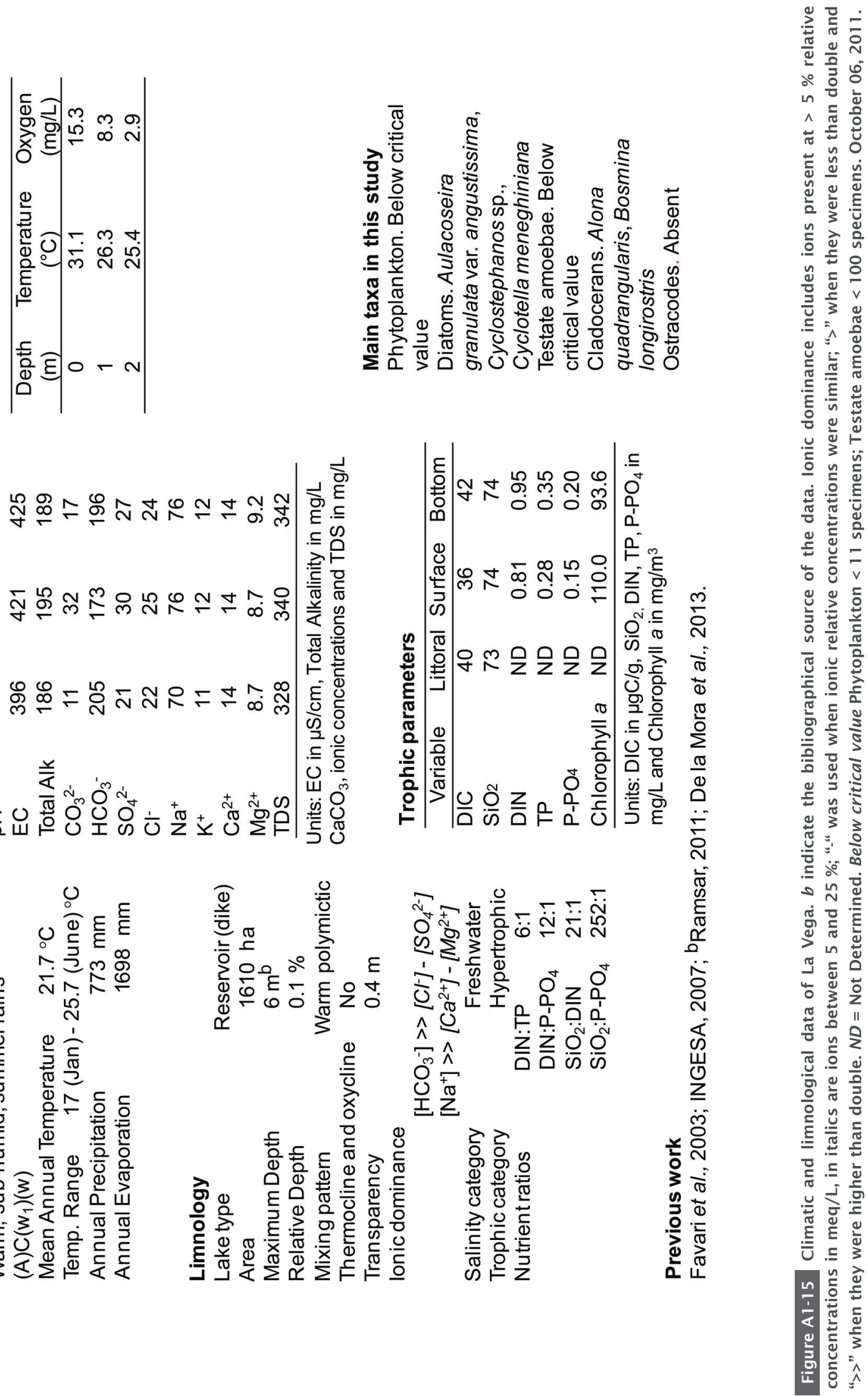

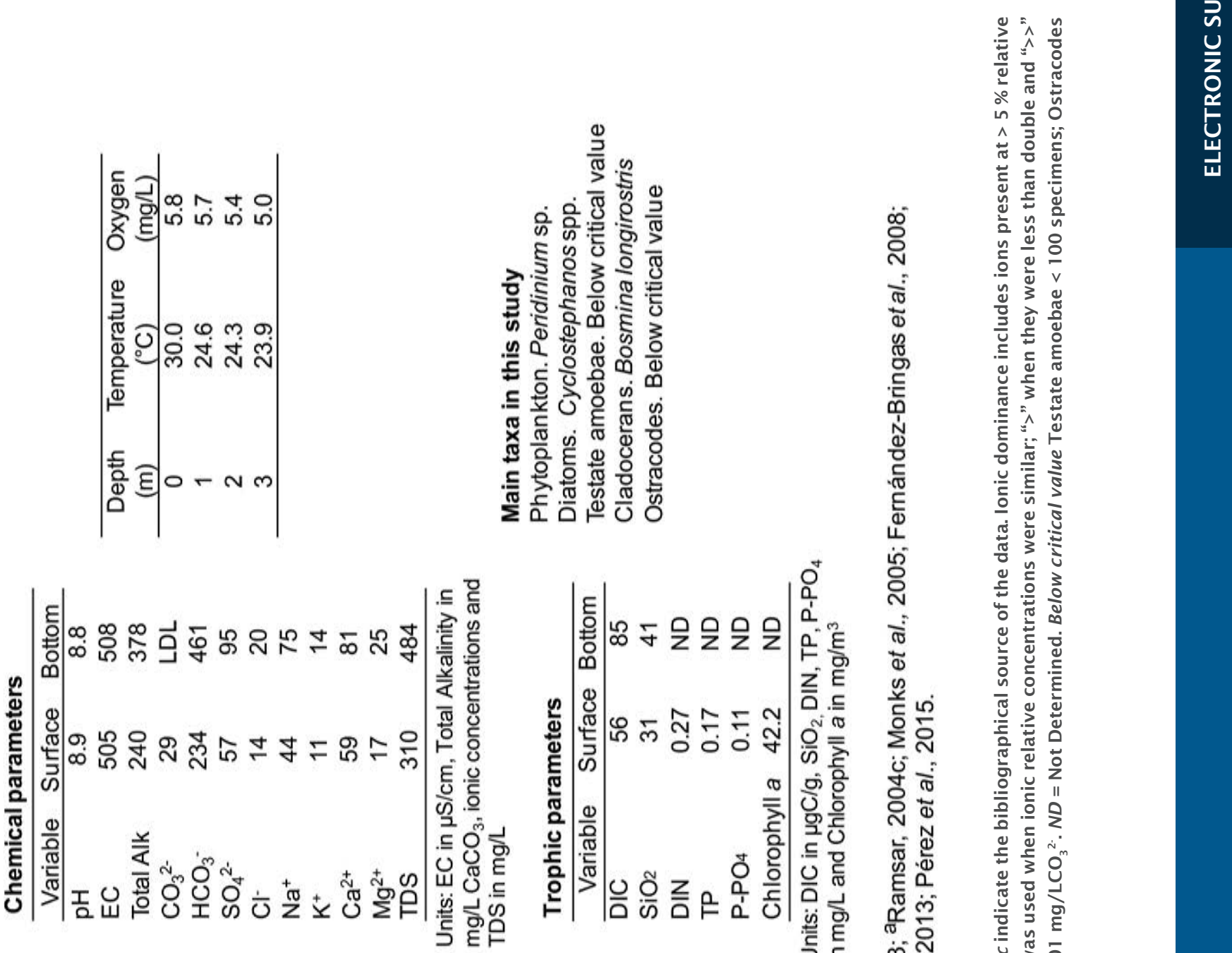

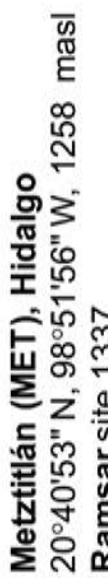
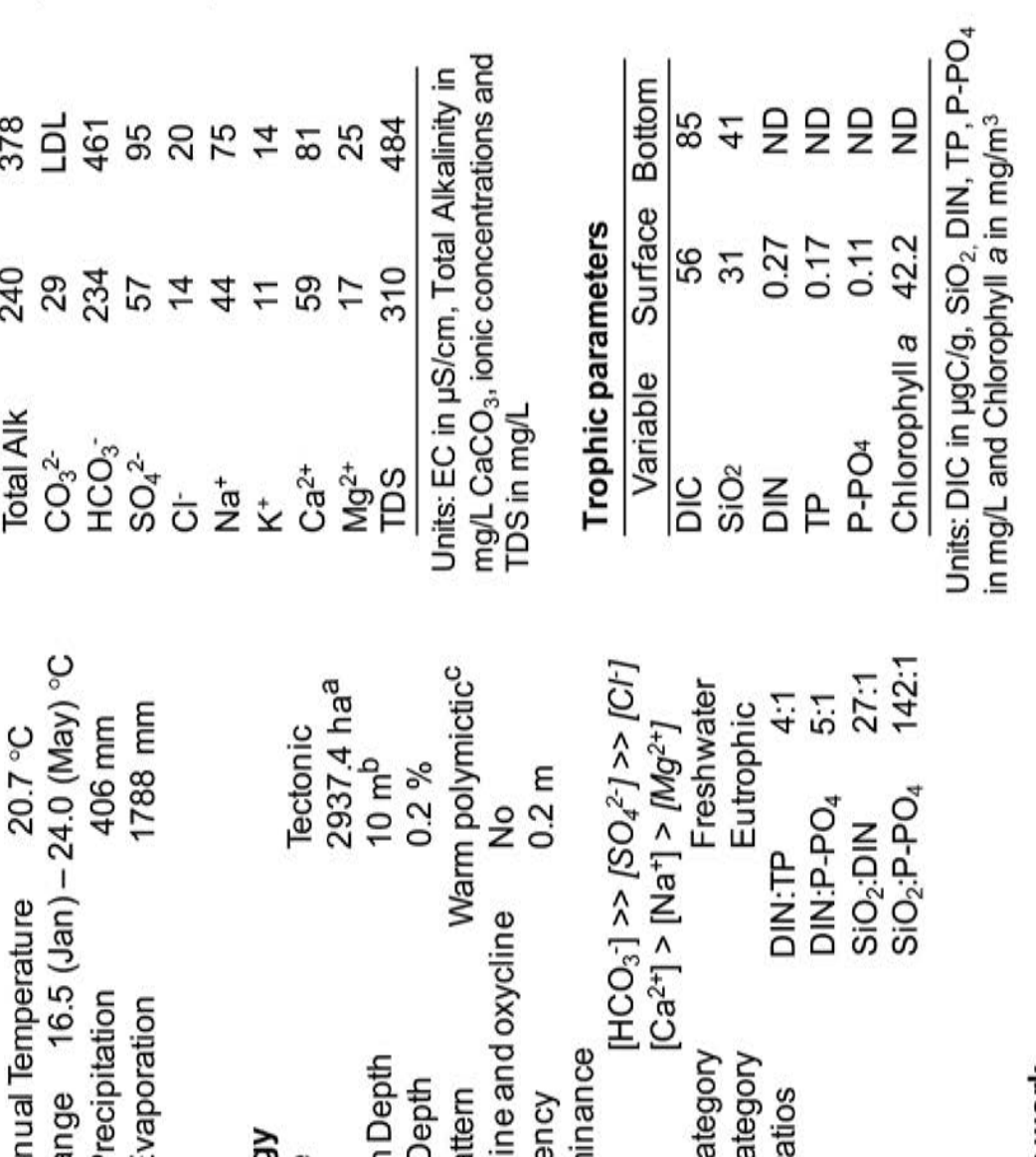

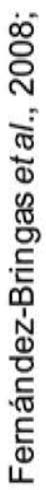

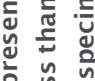

은

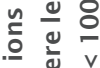

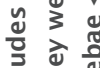

至 吾

ป

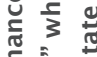

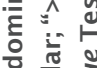

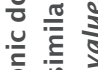

으

त

등

ำ

कั

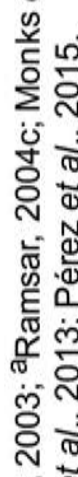

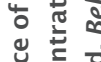

产

गู

定

는 운

흘

월

站

స

豞

능

둔

$\circ \ddot{\circ}$

०ै

䒕

in

ป ธ

¿ उ

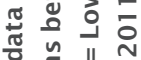

뜨 음

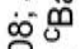

윰

กิํำ

ㄴํㄴ

능

응

至 을 응

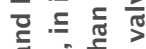

उते

농

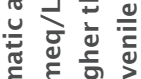

튼

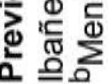



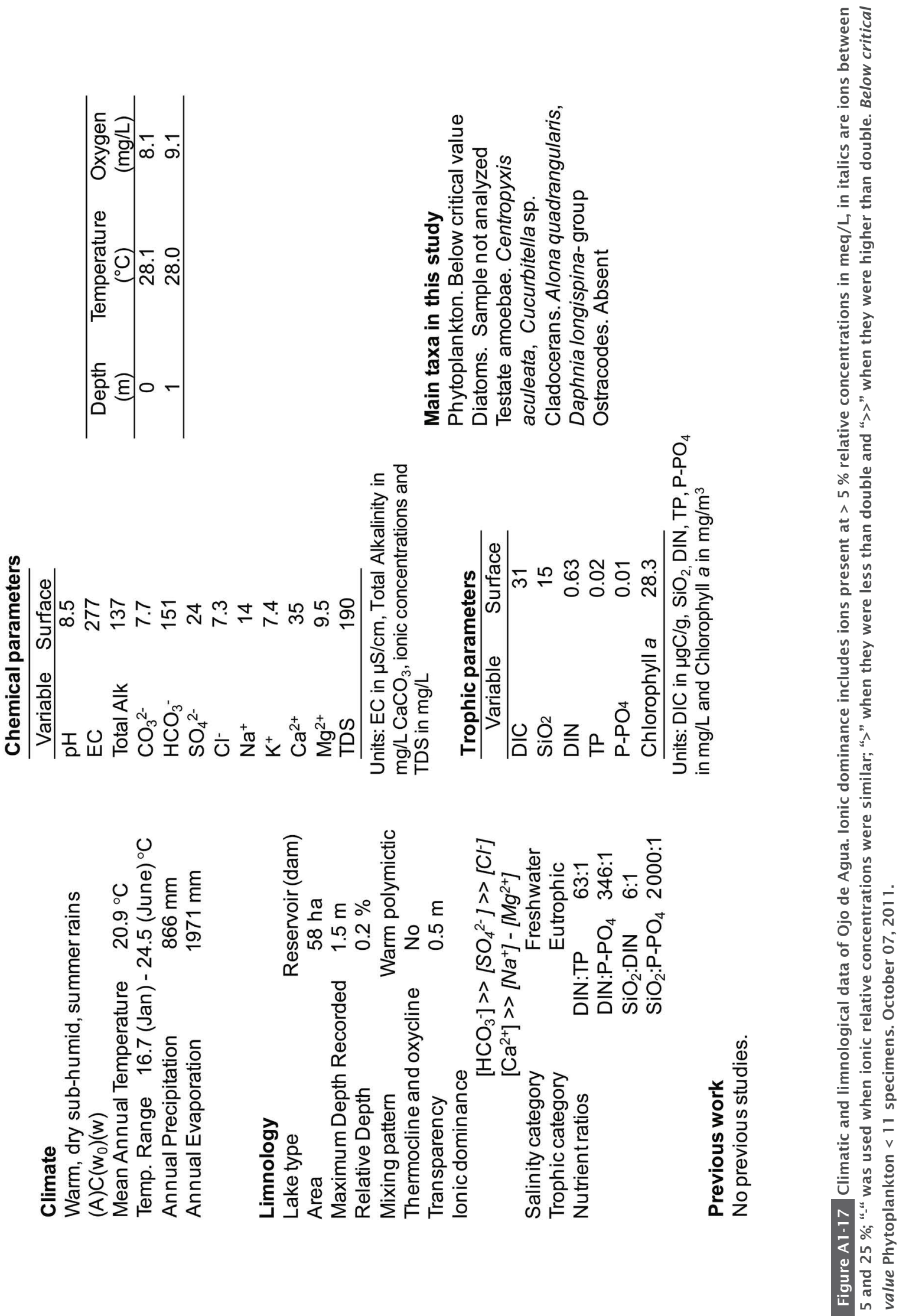

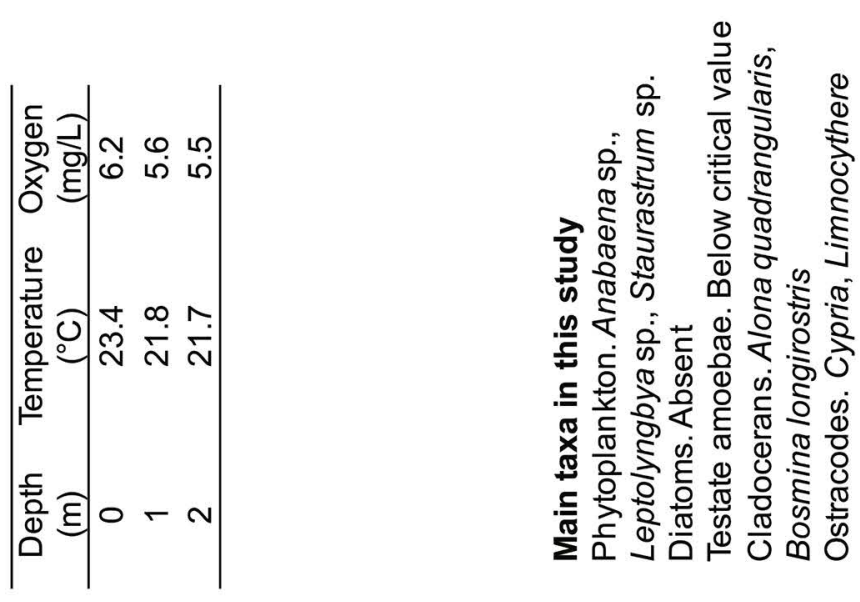

ํํㅇำ
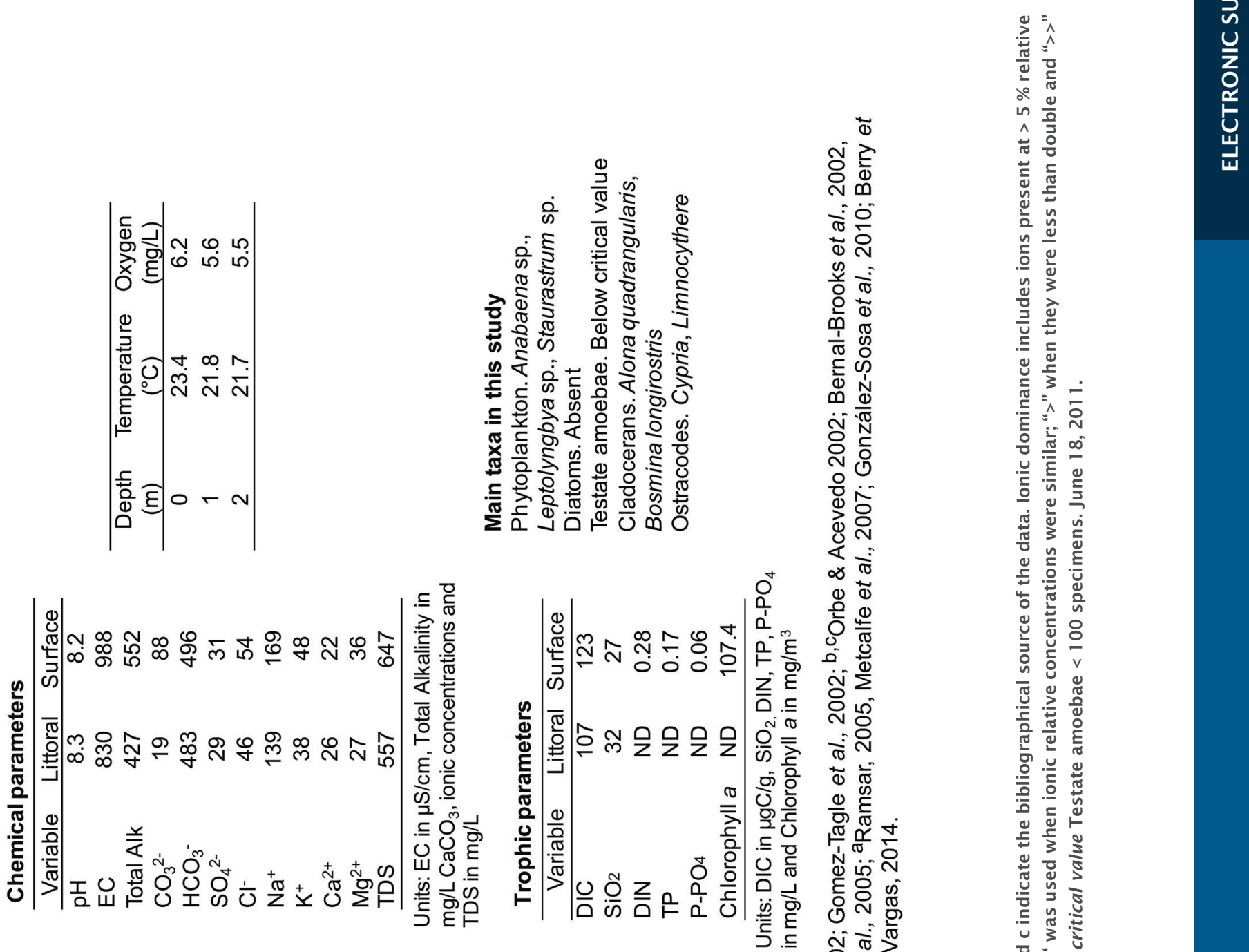

๘ั0

을

党离

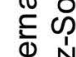

零

ญิํํㅇำ

ํํㅇ

용

눈

$\infty$

잉 $\frac{\Phi}{\sqrt{0}}$

ก่

ㅇํㅇ

तั

屯市

$\frac{0}{0} \frac{E}{\pi}$

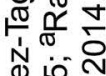

ข้

ठํำ

กิ่

ठำ

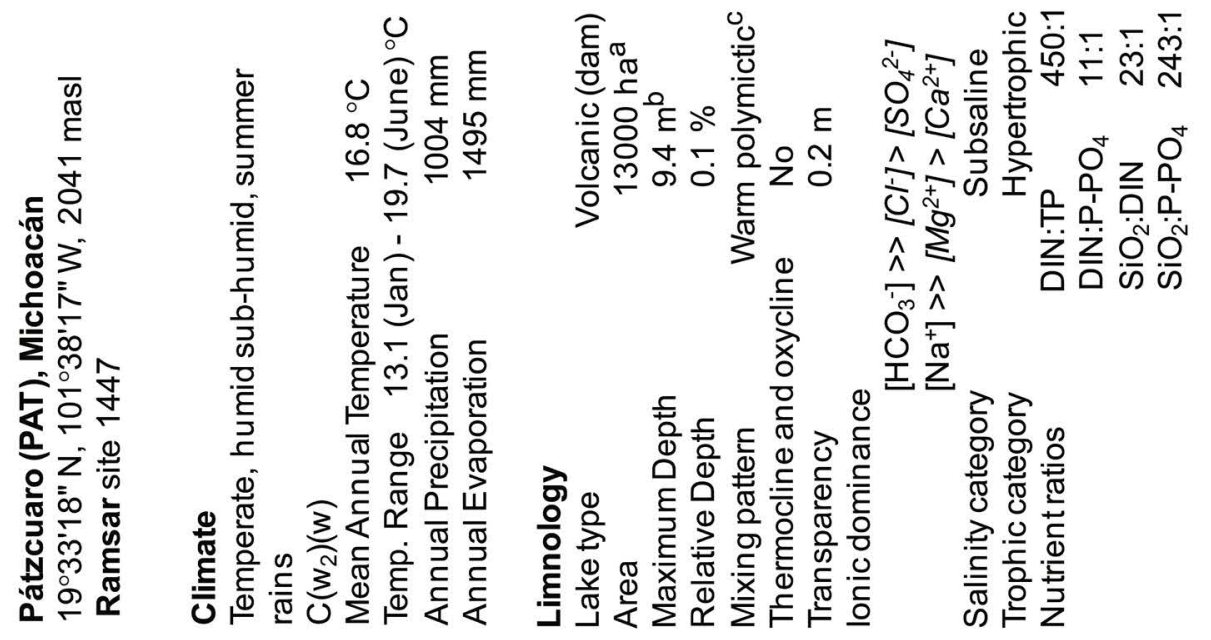

जิ

응 突 공

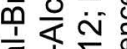

헝웡

늉

$\infty$ 产市

め

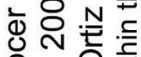

정 은

选交.

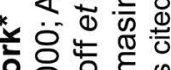

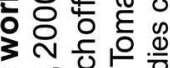

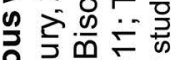

윽 응 훙ㅎㅇ

ฮั 

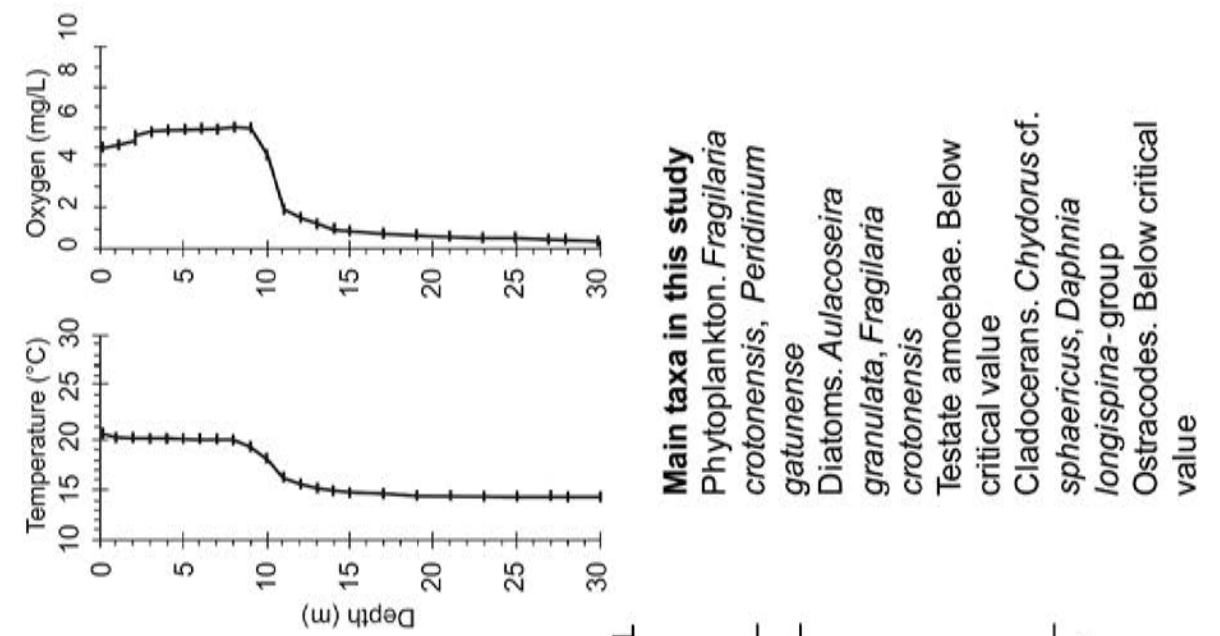

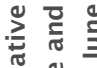

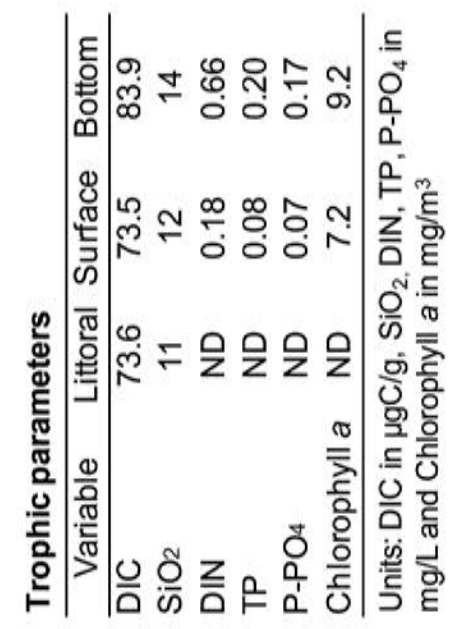

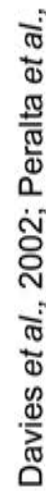

ㅇํㅇ웡 궁

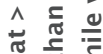

范

흥

$\check{c} \frac{1}{3}$

은 홍

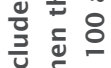

$\Xi \frac{5}{3}$

$\stackrel{\mathrm{g}}{\wedge} \stackrel{\mathrm{d}}{\circ}$

䍃

을

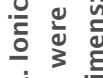

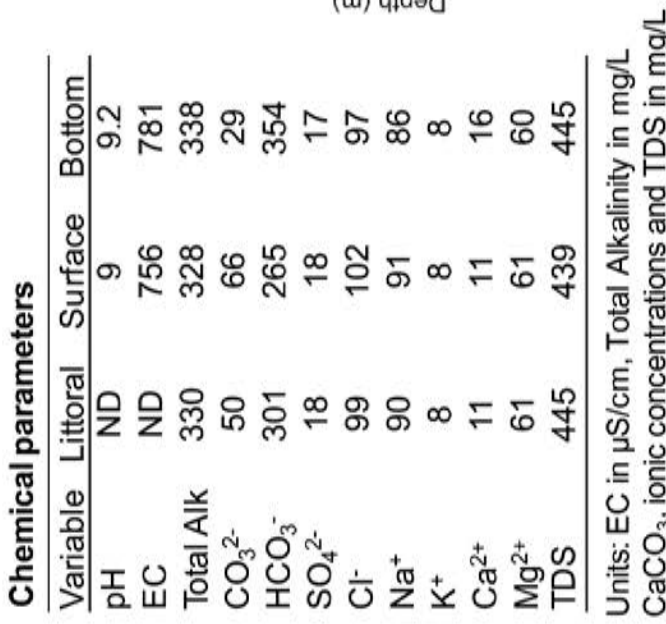

ชั่

ป⿱艹

ฮั

递

ปั

일

ชิำ

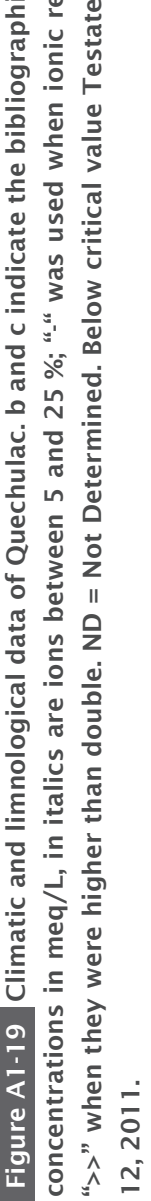



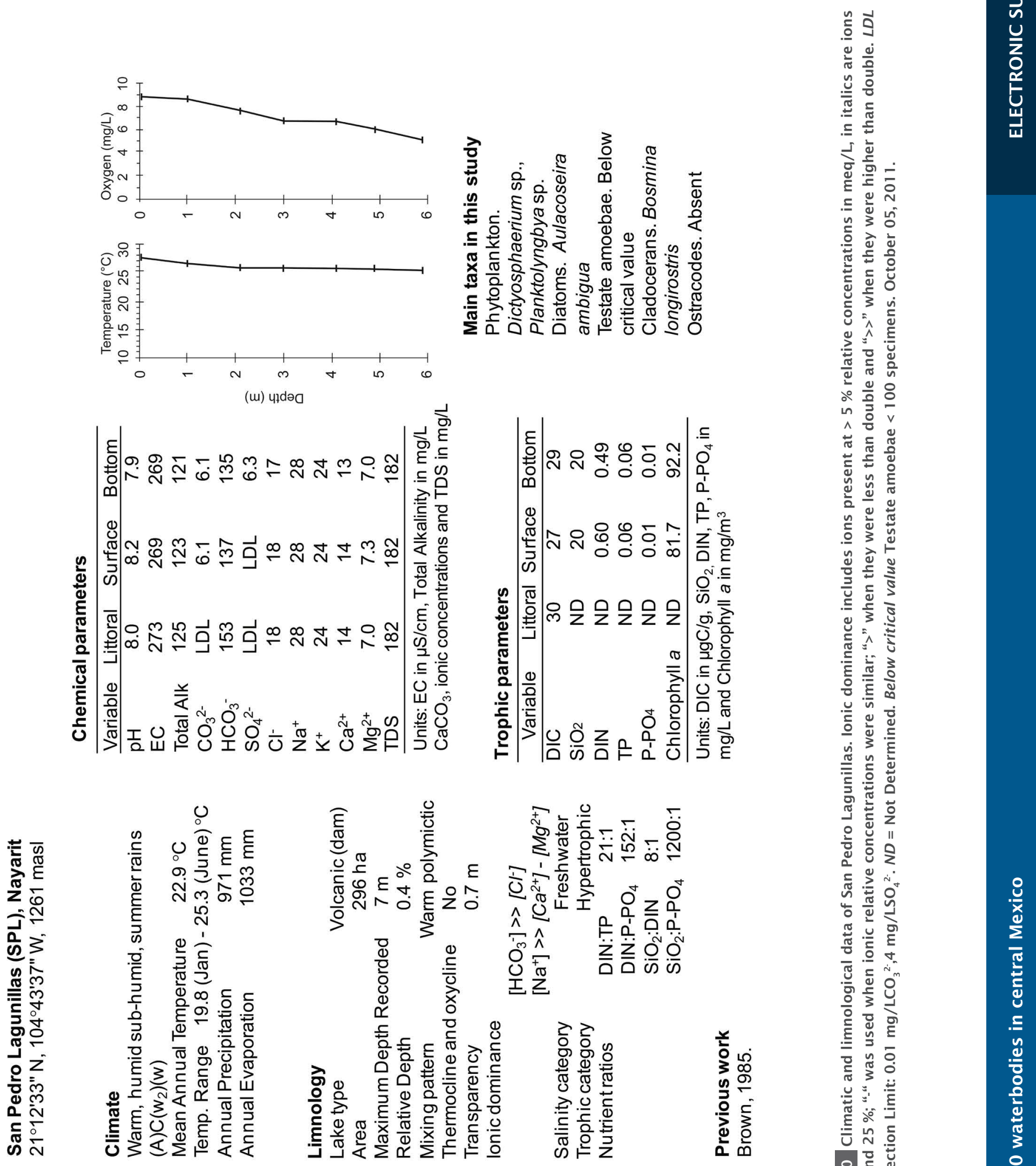

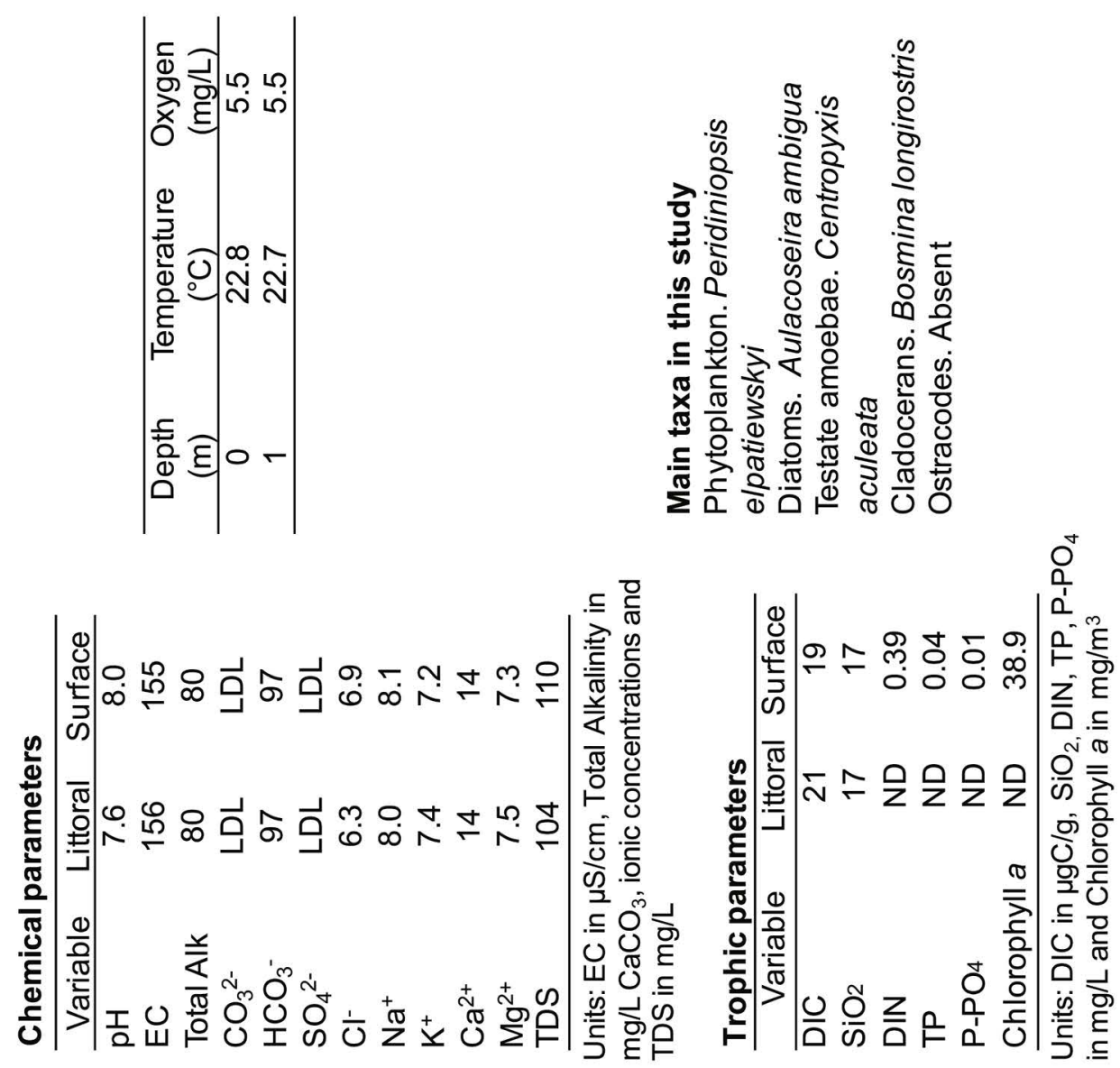

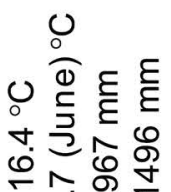
$\infty$

这 $\frac{1}{\frac{1}{0}}$

(亠)

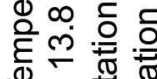

뜽

는 z

ญํ

ले

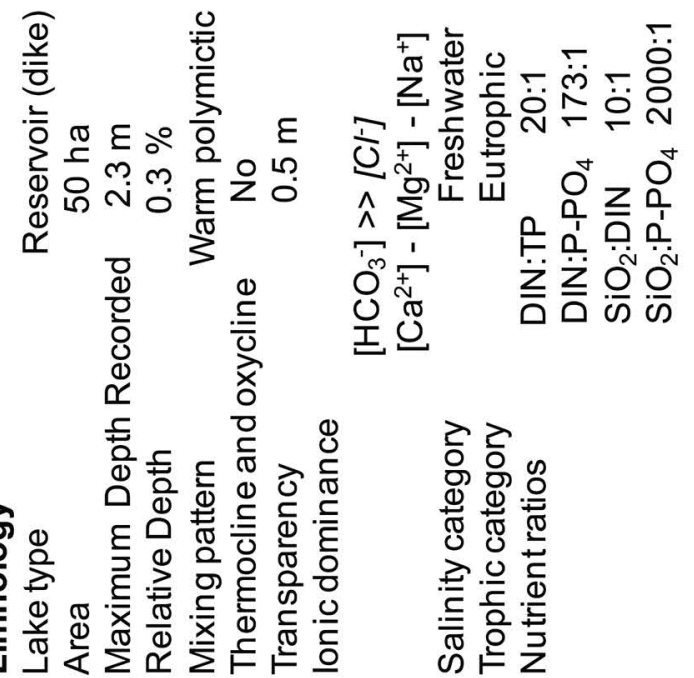



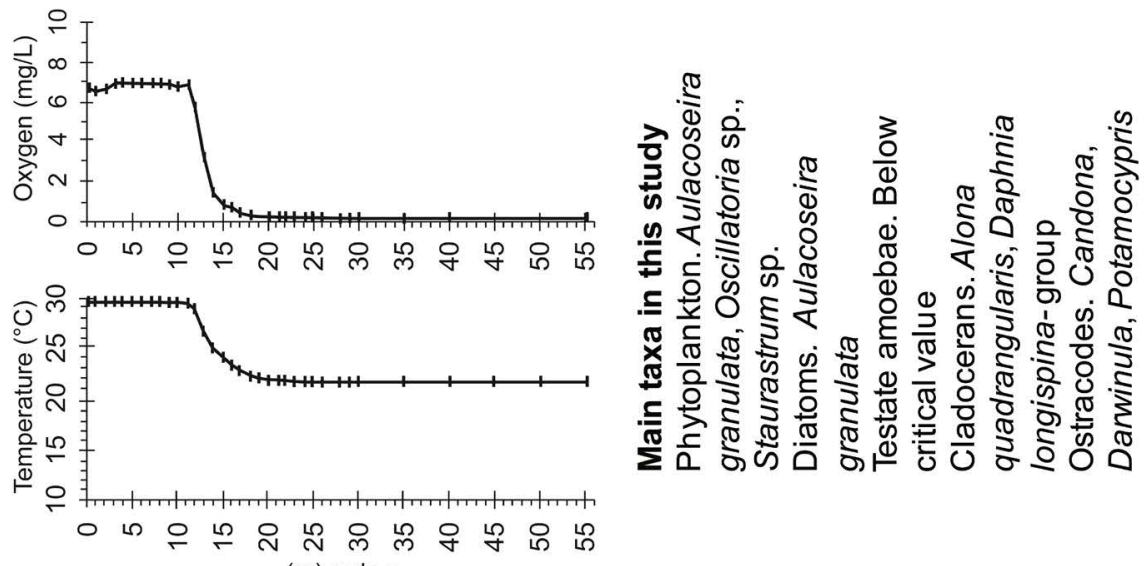

(u) yzdə0
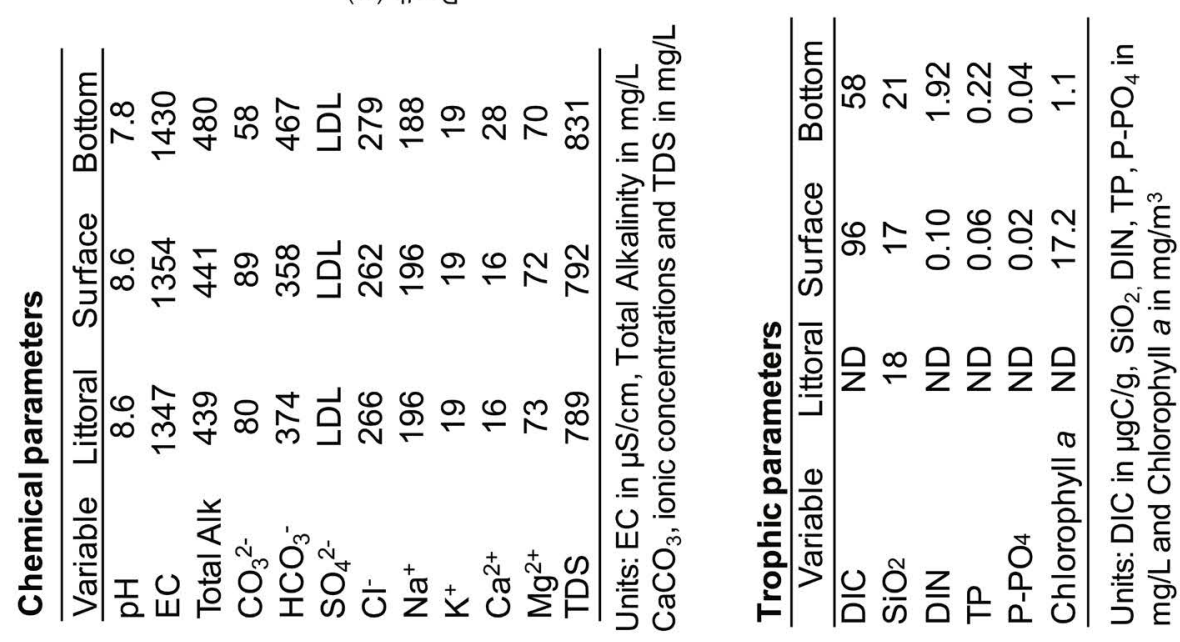

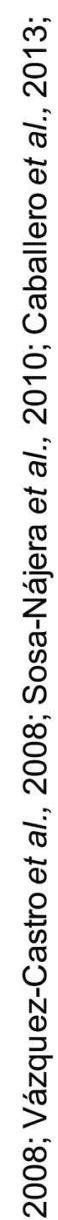

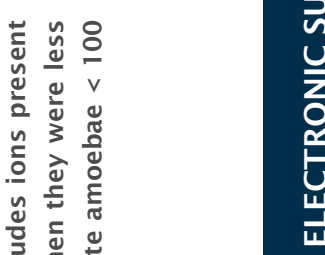

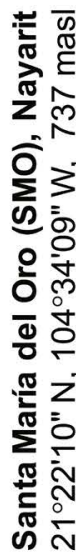

O

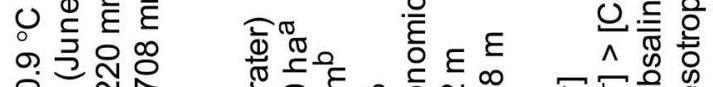

方

.

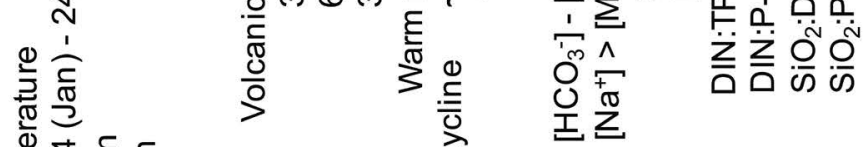

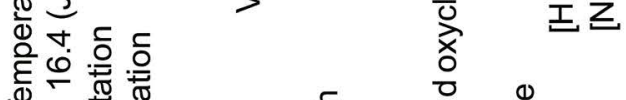

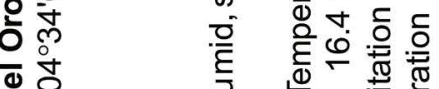

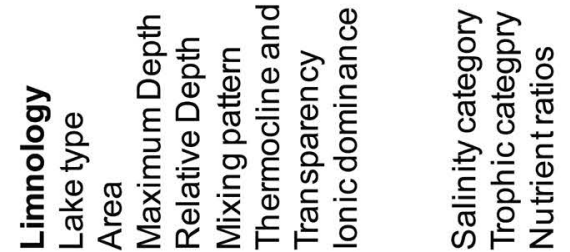

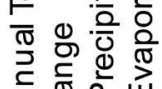

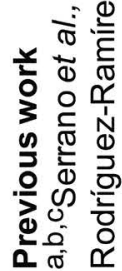



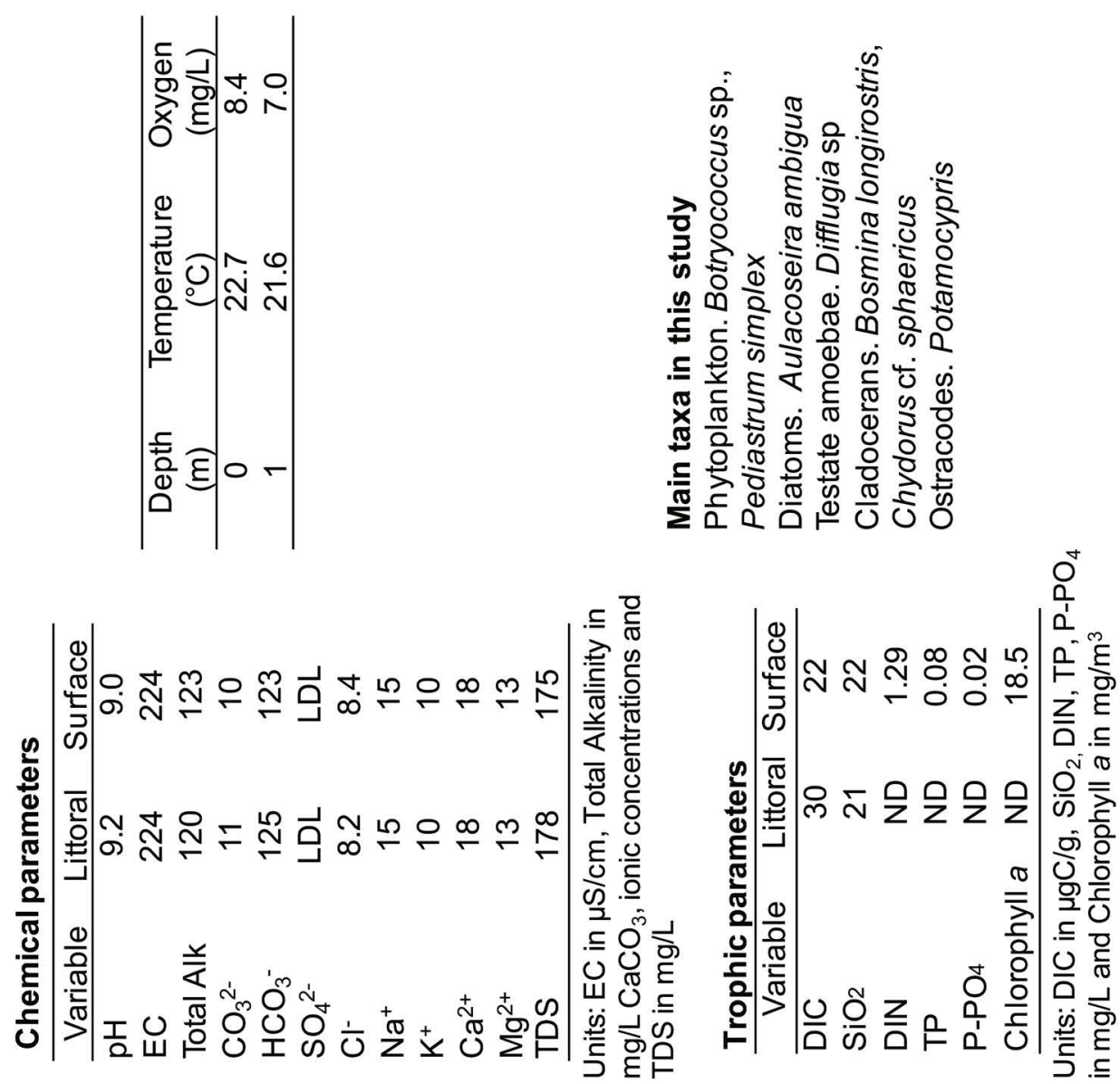

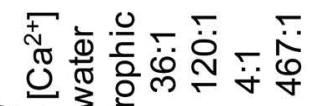

हृ

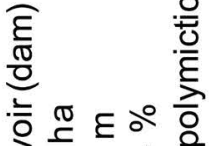

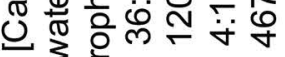

论

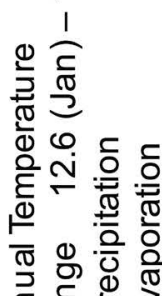

웅

옹음

胥 Z

跉

蛋 సे

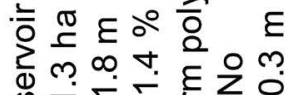

$\stackrel{\infty}{\mathbb{1}}$

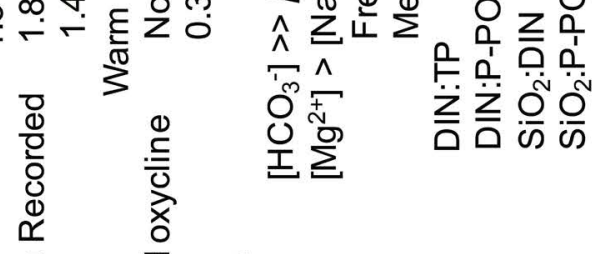

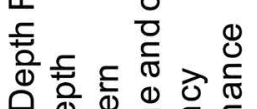

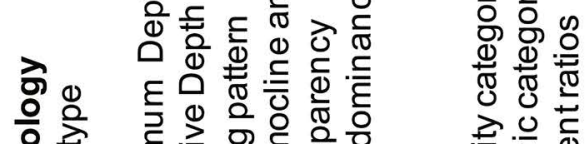

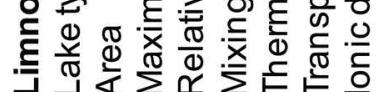

곧을

든 응 온 

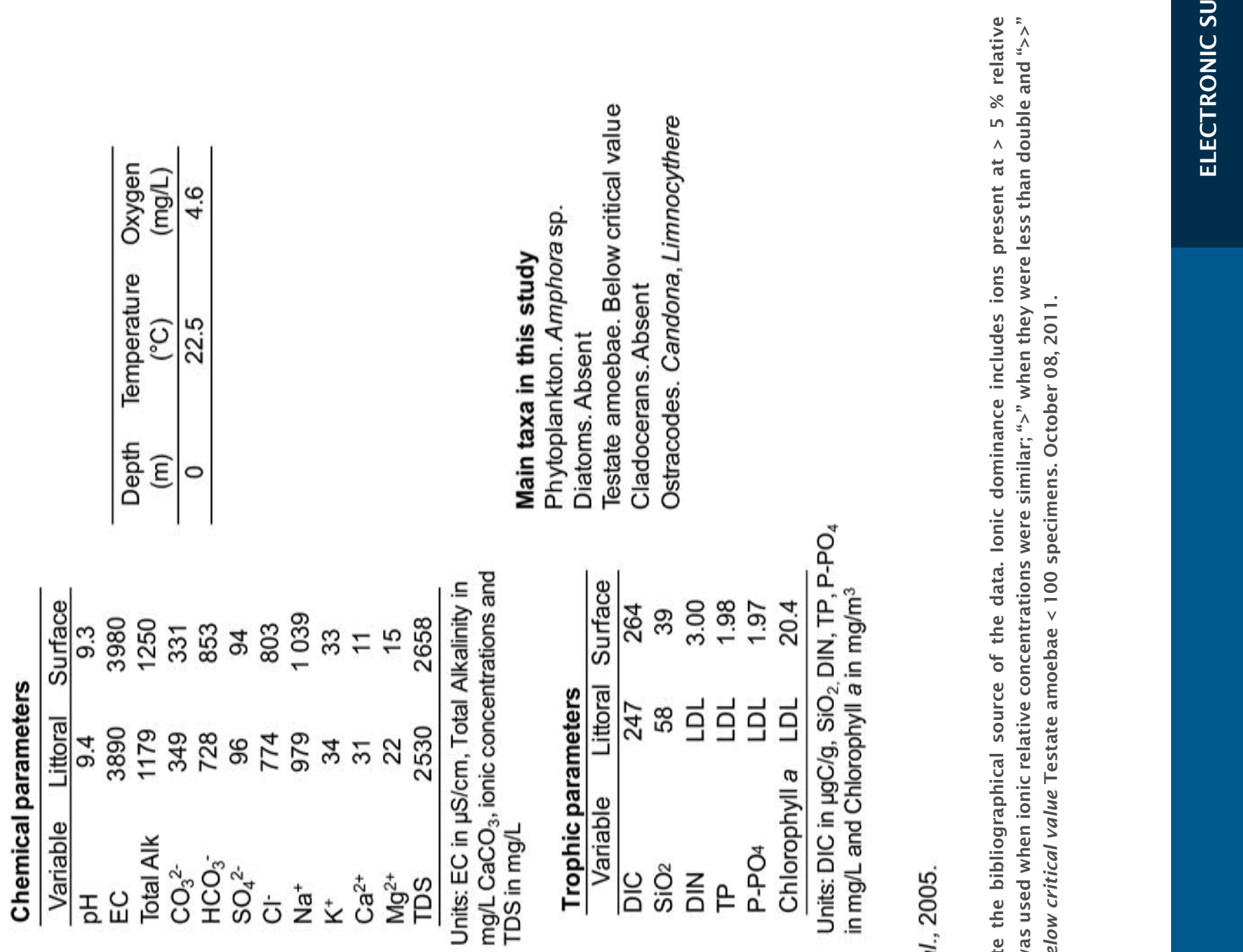

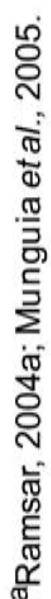

कू

O

茴

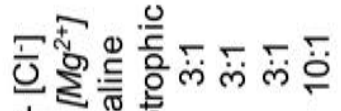

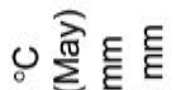

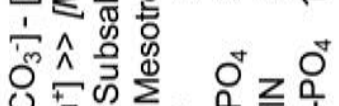

守

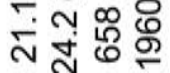

ס

IZ

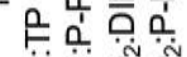

애류

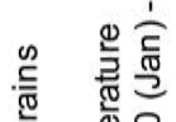

ㄲํำ

을운 들 을

产, 竞

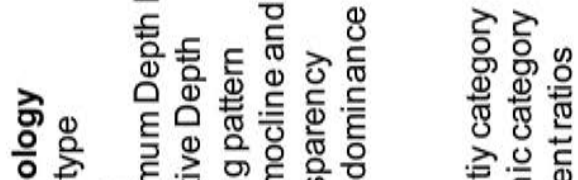

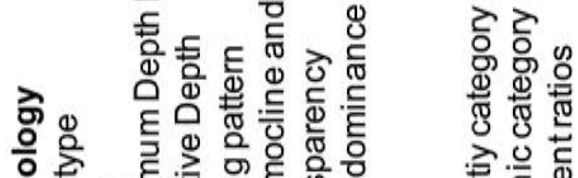

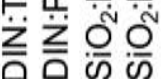

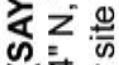

的考

준

है

苋莡

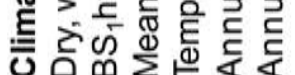

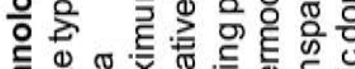

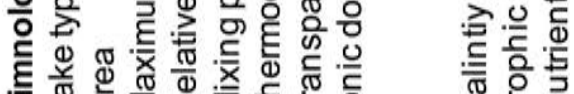

离은

줄 을

究 in

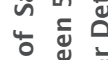

范

तु

ํํำำ

응 ํํำ

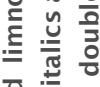

든

造 

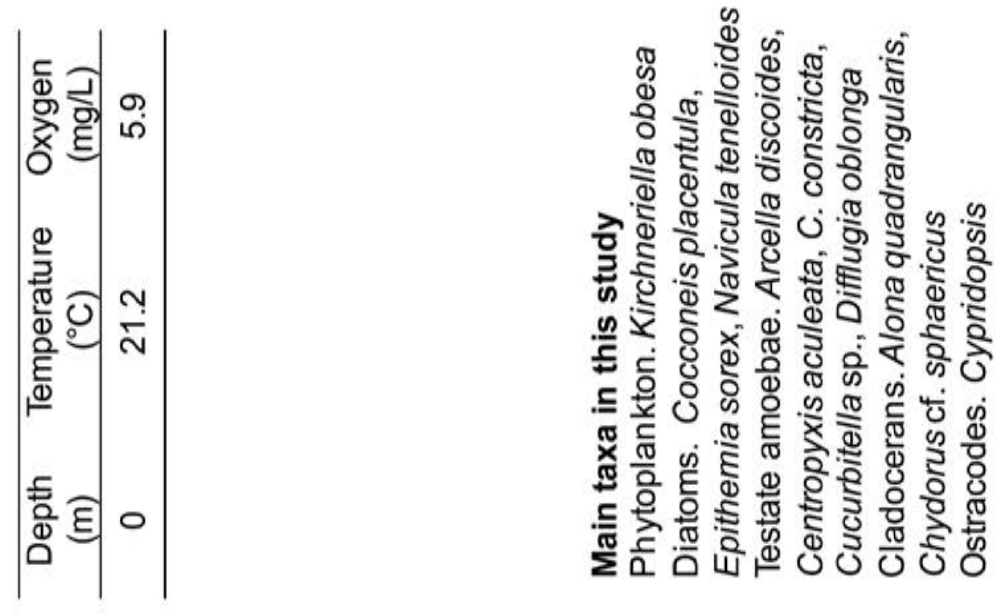

$\ddot{\circ}$

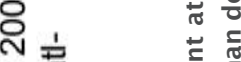

ฮั่

N

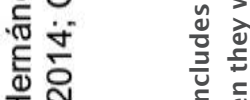

또을

पू $\frac{1}{9}$

需苋

๓๐

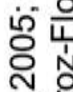

슬

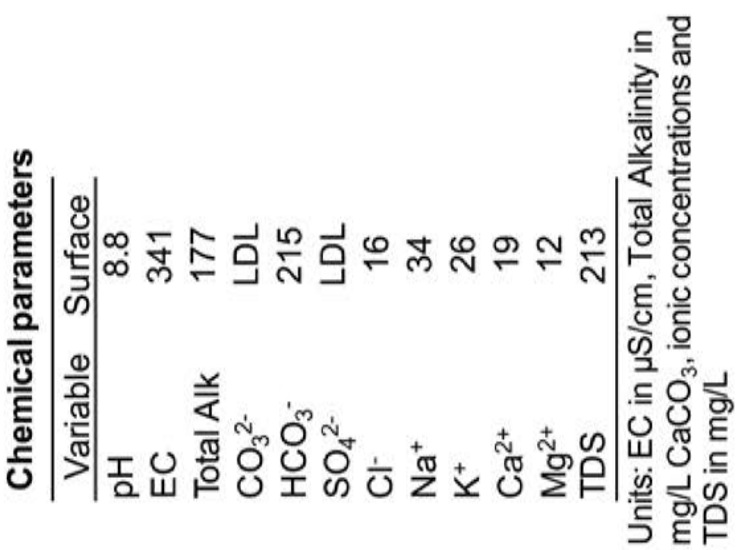

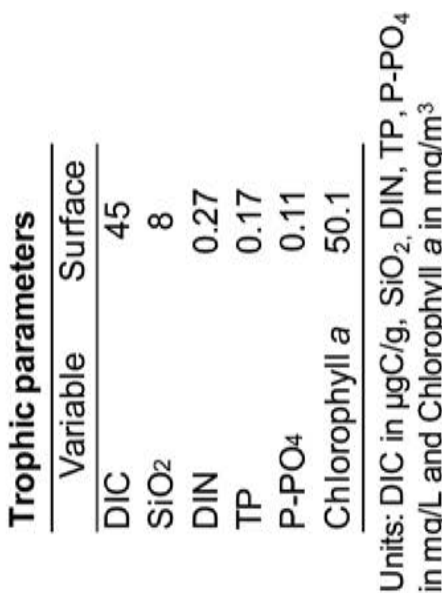

ऽЕ

- क

ำ ำ

고 ㅇำ

เ่ํㅇㄷㅇ

ำ

ㄴำ

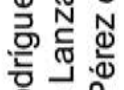

ㅎํㅇ 응 ำ

,

产

娄讨

ํํํ छे

ฌ ญับ

ป็ ठำ

늘

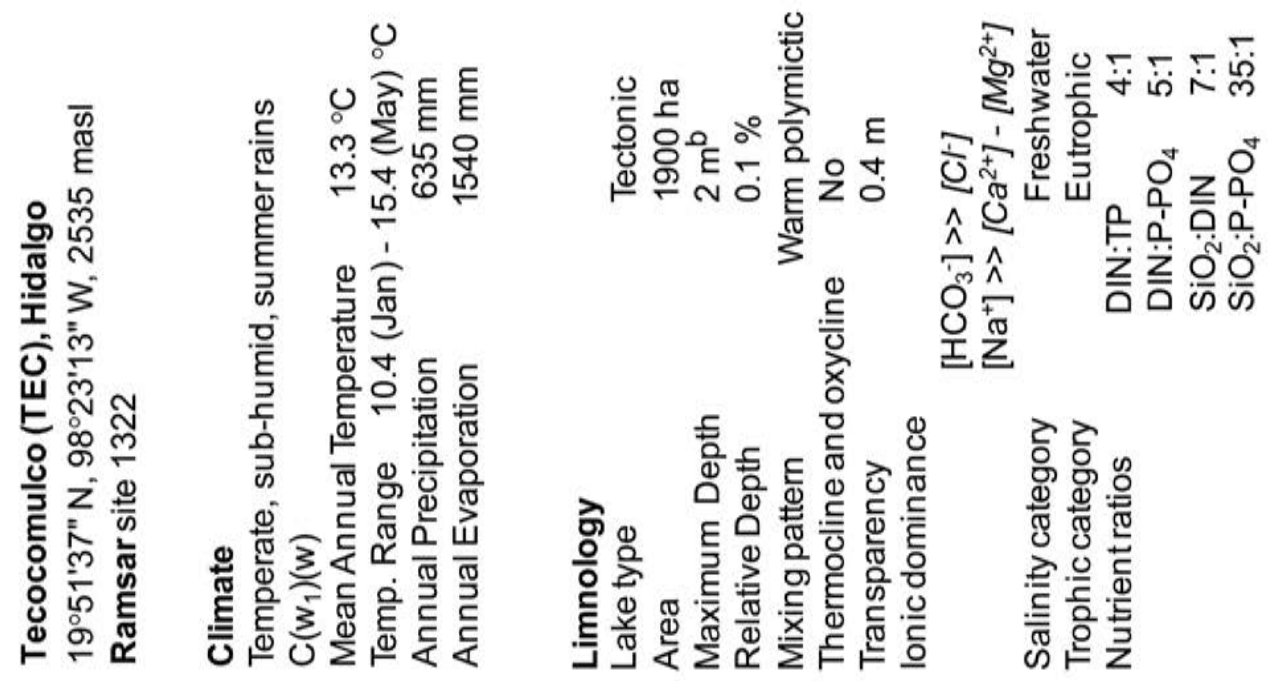

त)

००

농

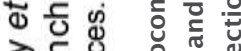

ถ่

당

$\infty 0 \%$

๙่ㅇํㅇ

ป็

茫势

웧ㄷㄷㄴ

ฮู

N

ฮั

즌 흔

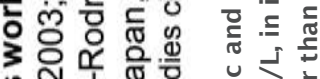

กำ

है छัँ

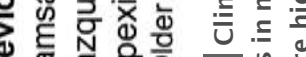

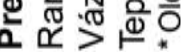



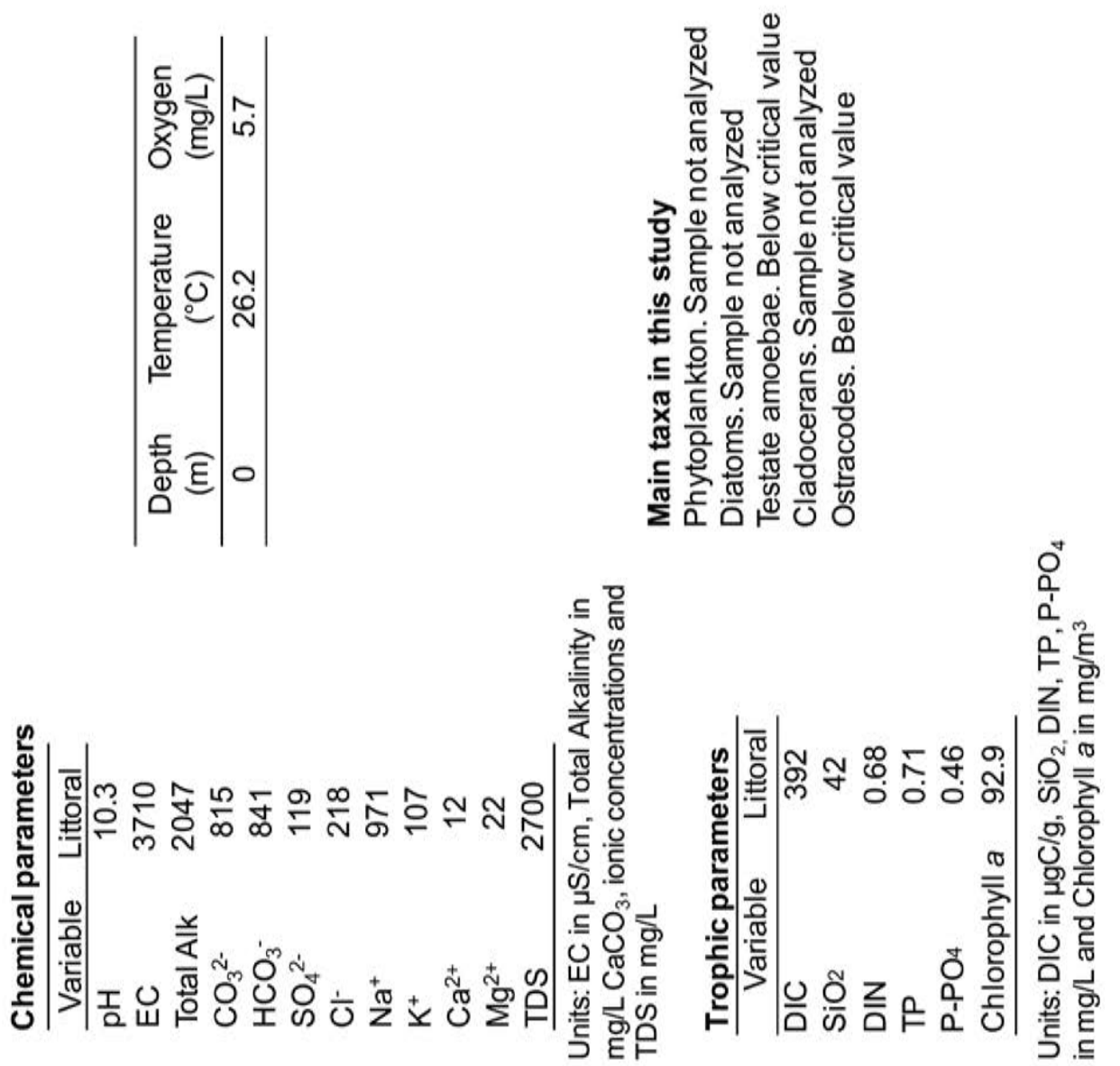

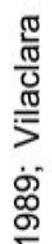

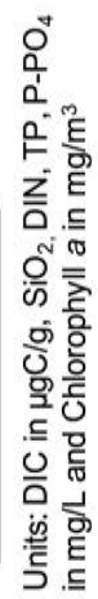

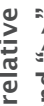
ㅇ in $\frac{0}{3}$

ㅎํㅇํㅇ

立

ขै

ก v

ֻู

$\infty$ เ

뜬 은

造

(1)

ญ

늘

뜨.

ஸ்

๙

สั

衣

웜

은 은 ํำ

을 을

ญ ह

궁

导

Ð

흥

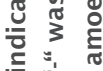

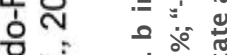

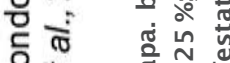

음 지

这 $\frac{\pi}{\frac{1}{\pi}}$

ஸ் ญ

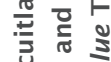

ปู เ

पे ह

ษ

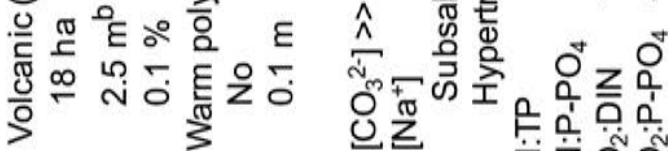

贾

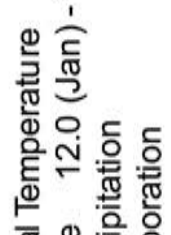

$\stackrel{\oplus}{ㄷ ㅡ ㅇ ~}$

艺艺次

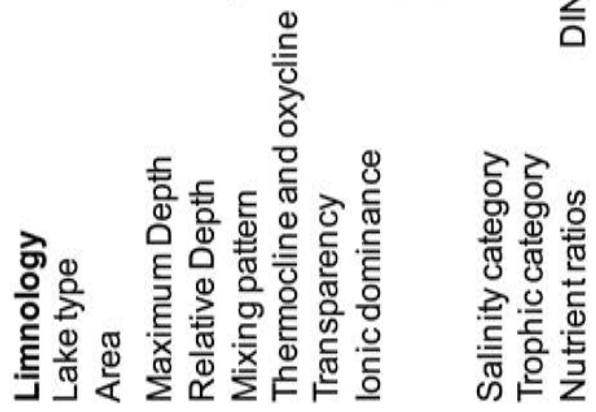

: 용

ธิ่

ฮิ

은 은

윽 응

믕

는 흔 는

\응

등 음

은 屴 

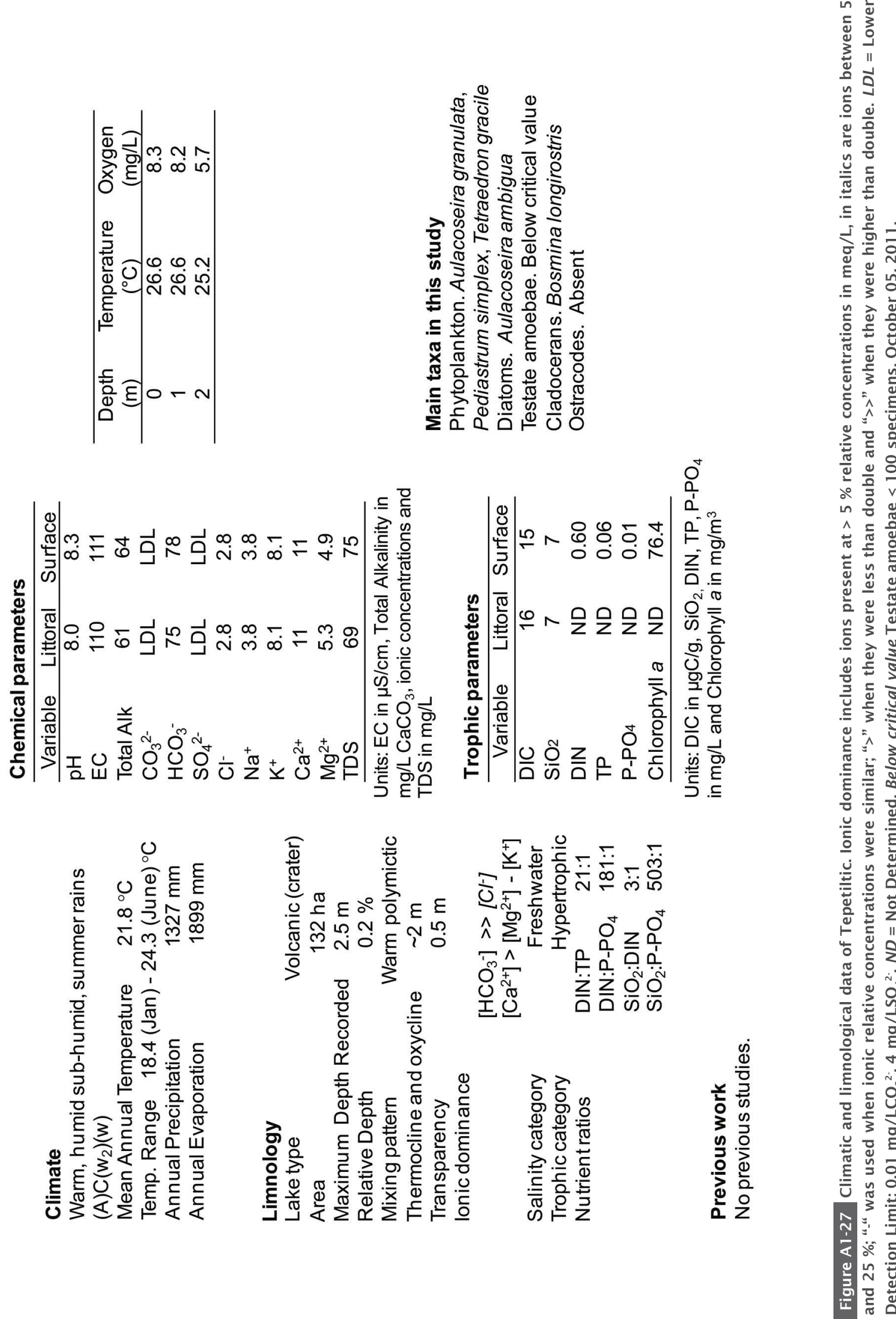

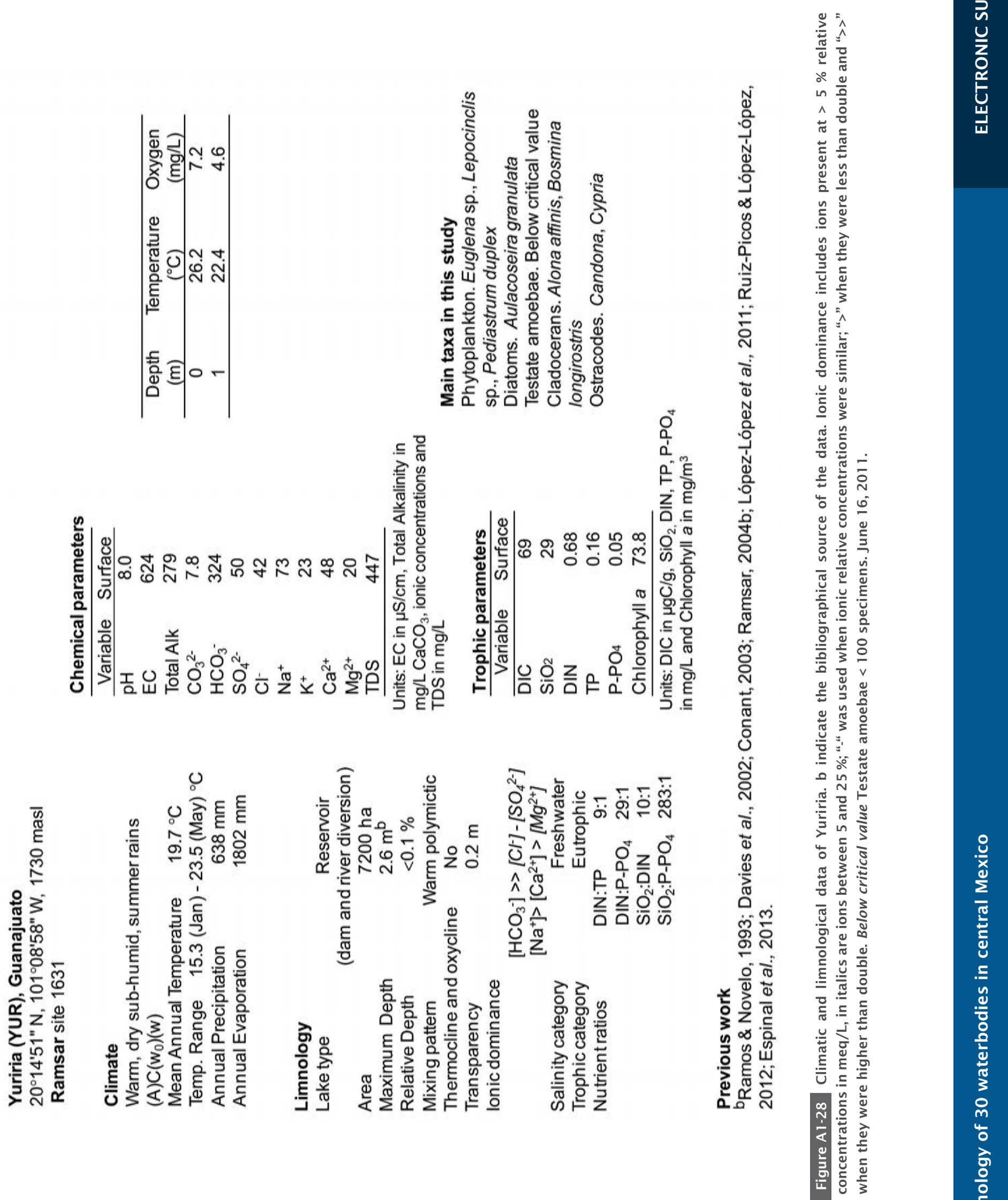

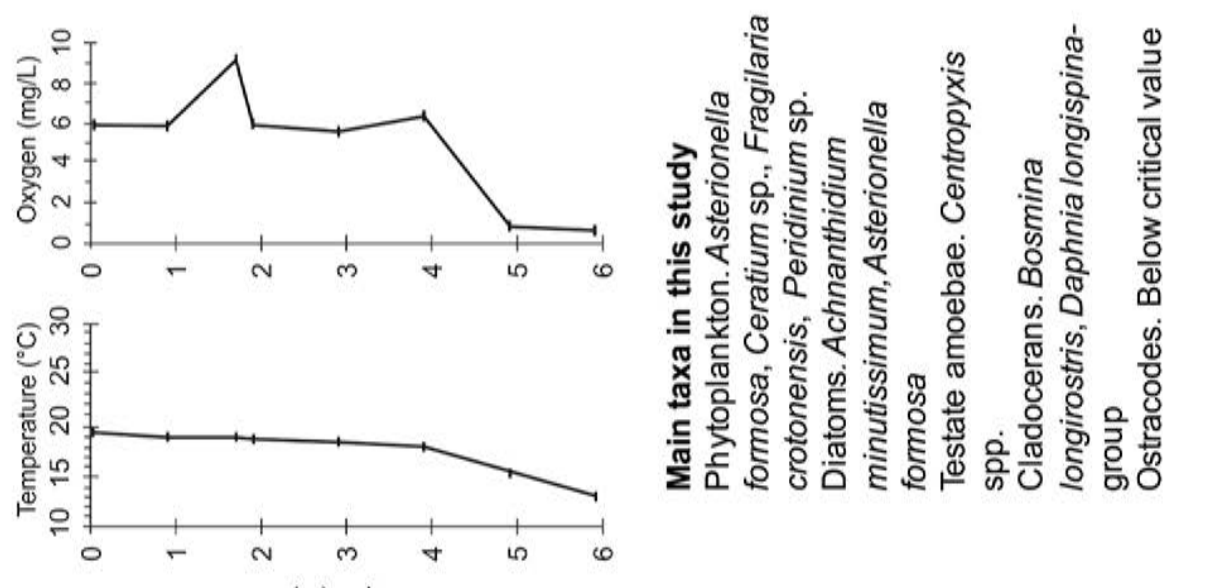

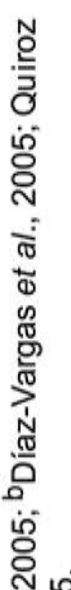
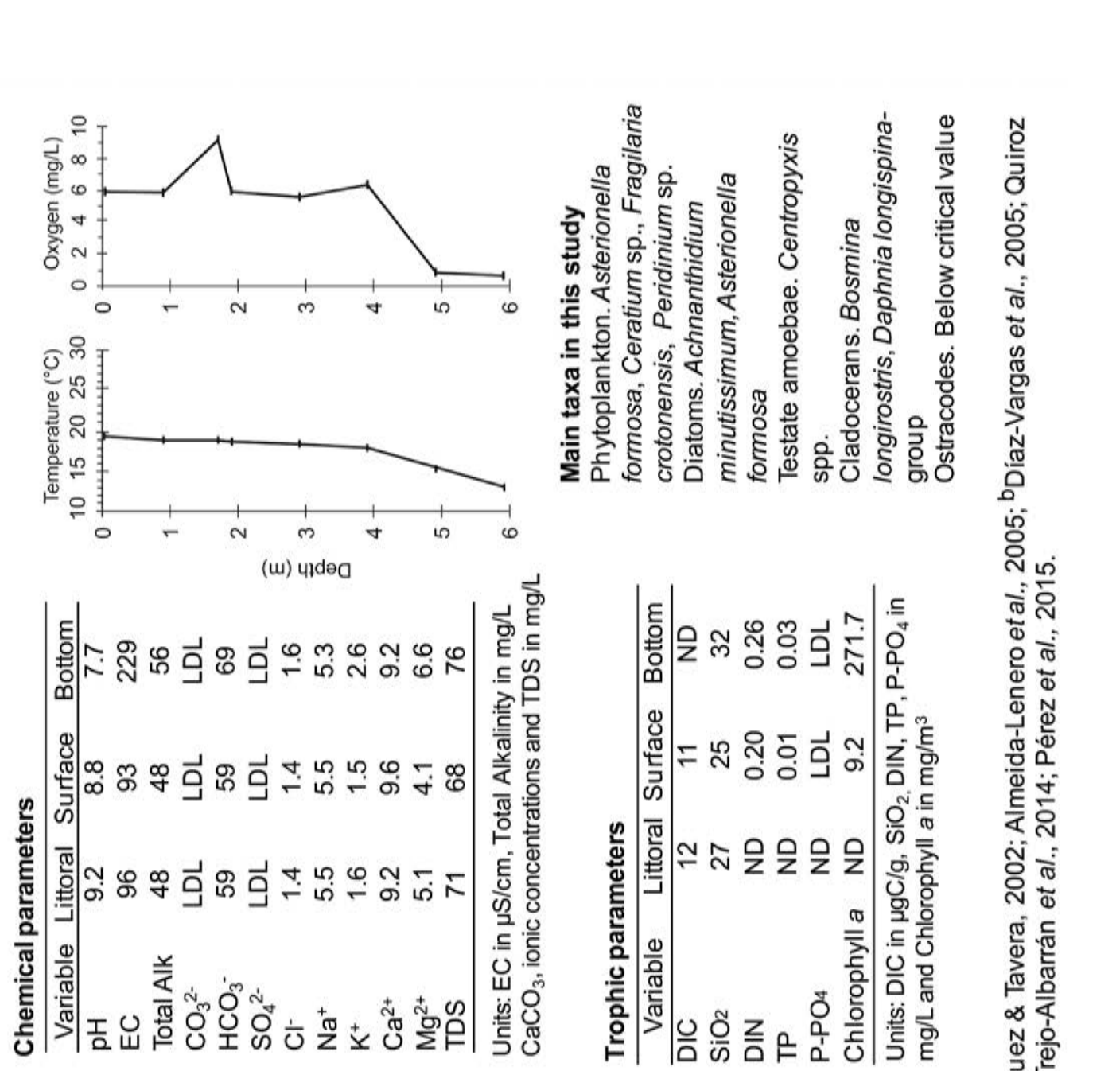

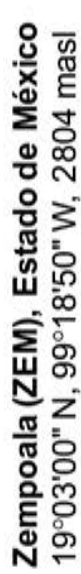
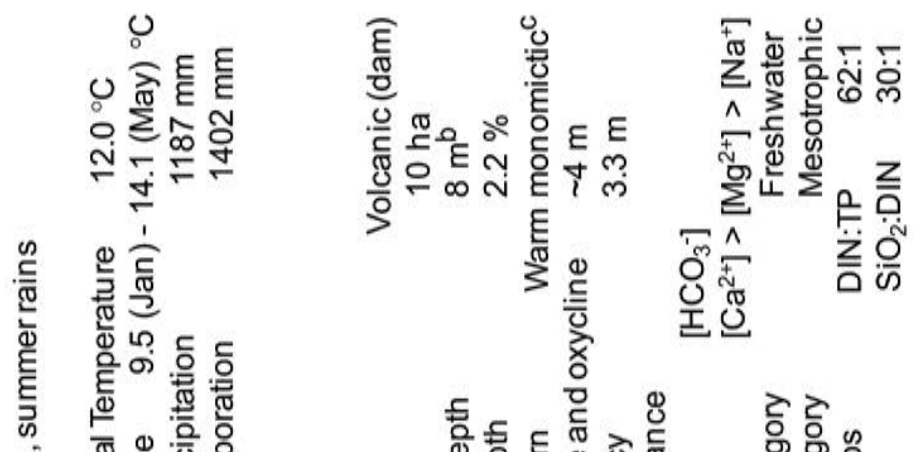

के बह
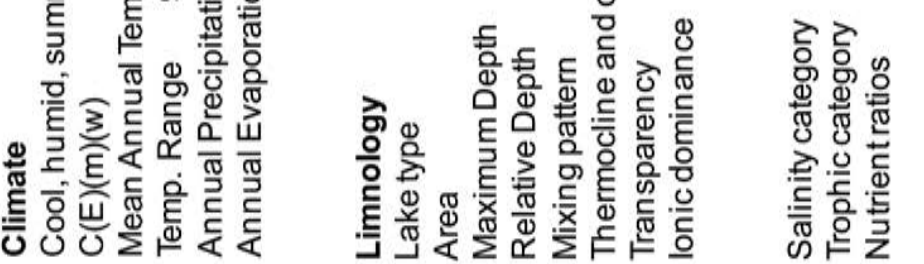

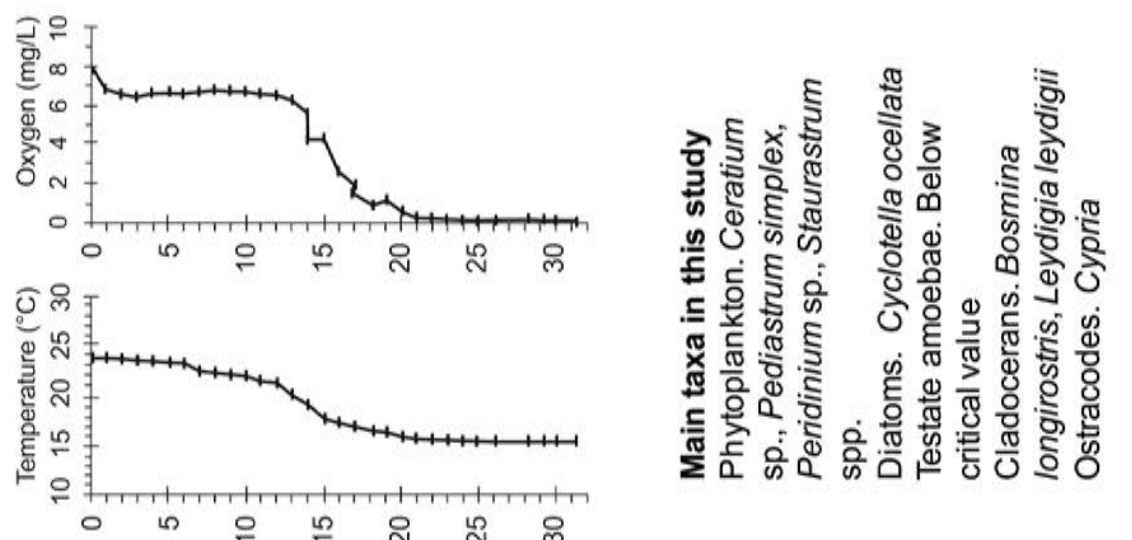

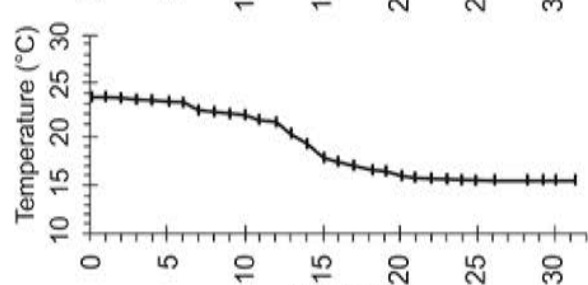

(w) प1 deg

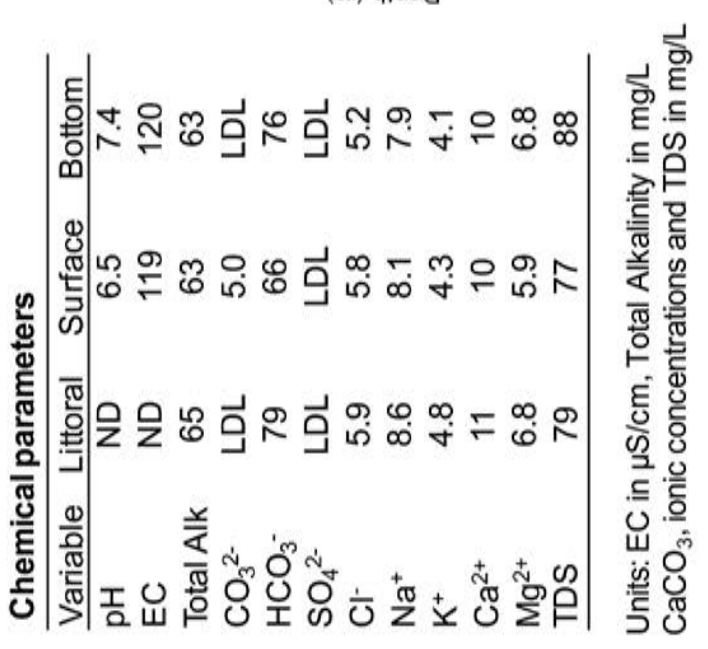

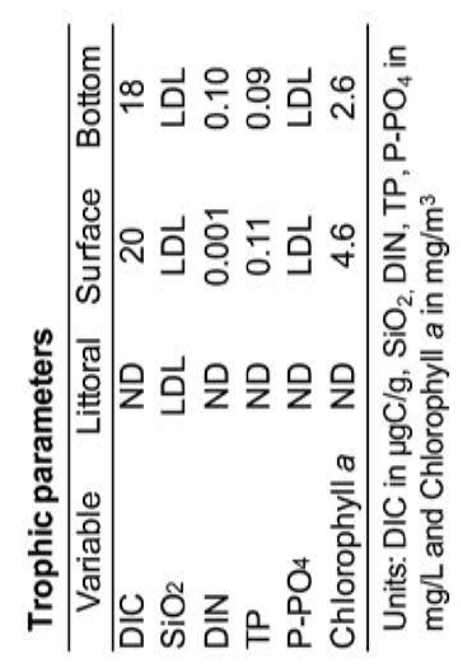

ষ্ণ

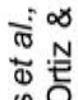
की 这 ปิ่ ๘ 㒖 은 능 तั 틍 유 ค่ ญ 응 ชั

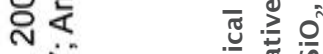

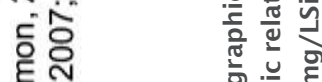
ह 든 $\frac{N}{2}$ $\sum_{\infty}^{\infty} \infty$ $\infty$ 응 능 ํㅗㄴ E ๓े ก่ क् बำ 문 बำ $\sum_{i}^{0} \infty$ 我 氖 宁 뜌

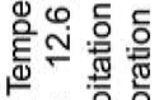

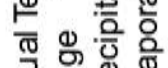
วิํํㄹ 高 तั 은

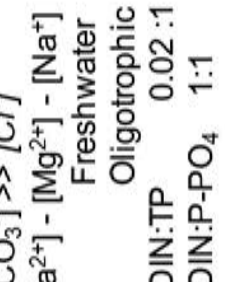

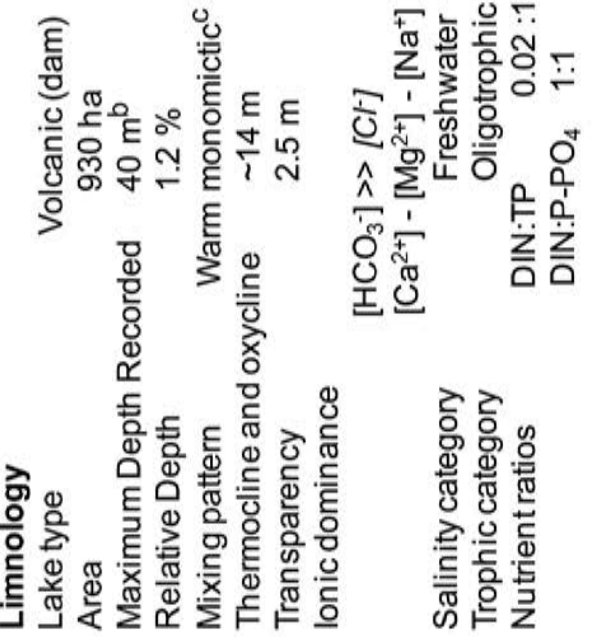

응 흔 ․ㅡㄴ

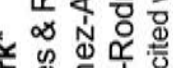

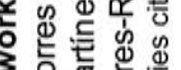

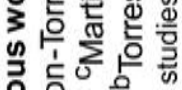
응응

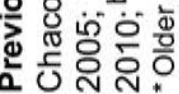

羿它
过

产気

政

\% 3

흔 할

들

造文

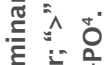

흥

․ㅡㄹ

흐 ํํㄴ

ญु उे के

त็

品

늘 हो

Чั้

ㅇํㅇ

응

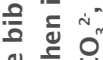

采

ปैं छे

후워

분

อั

$\rightarrow \stackrel{n}{N}$

등 응

N้ำ

垴

잉

范

뜨음

承品

을 응

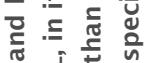

ㄴㅎㅇ

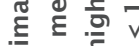

U. 

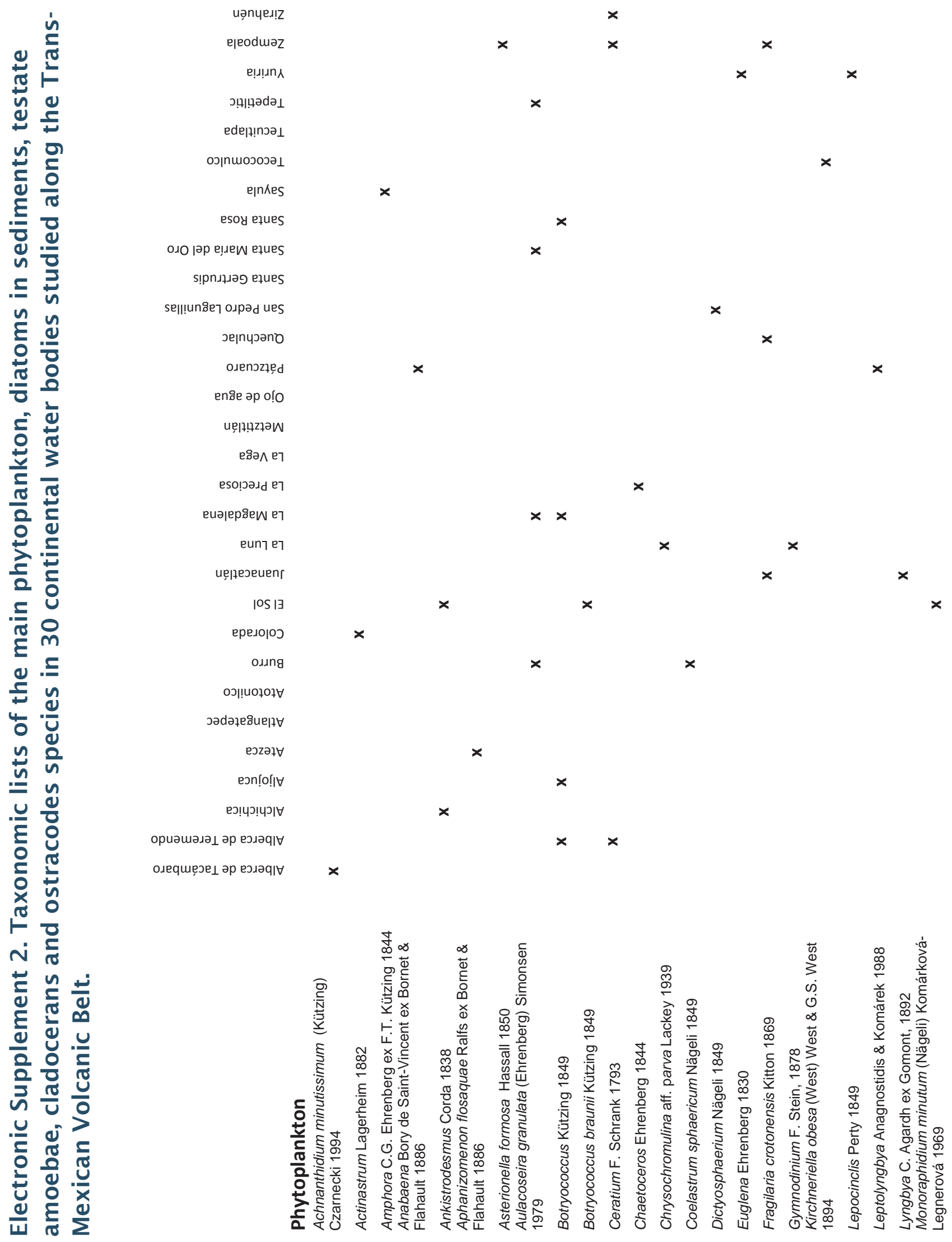

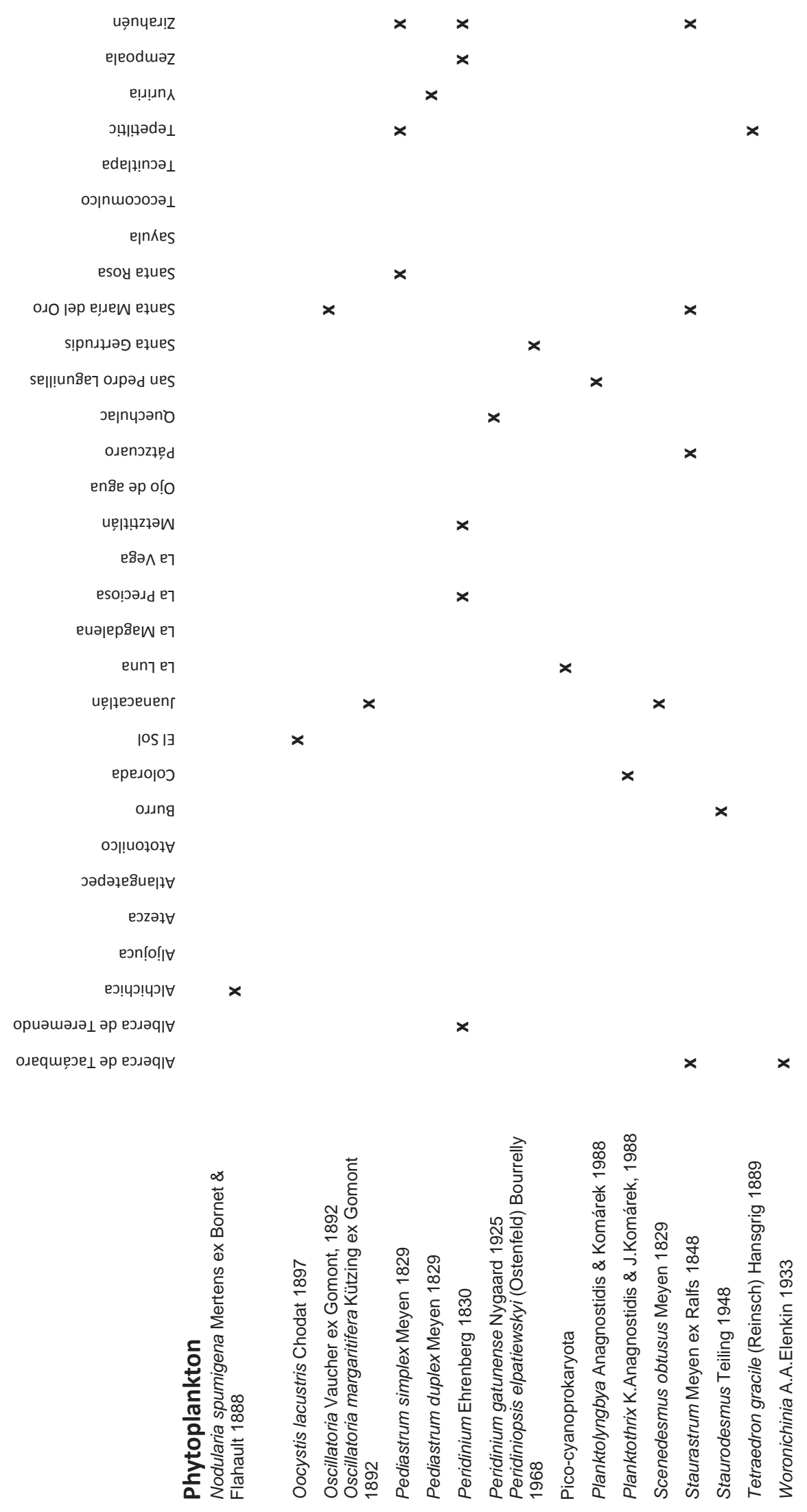


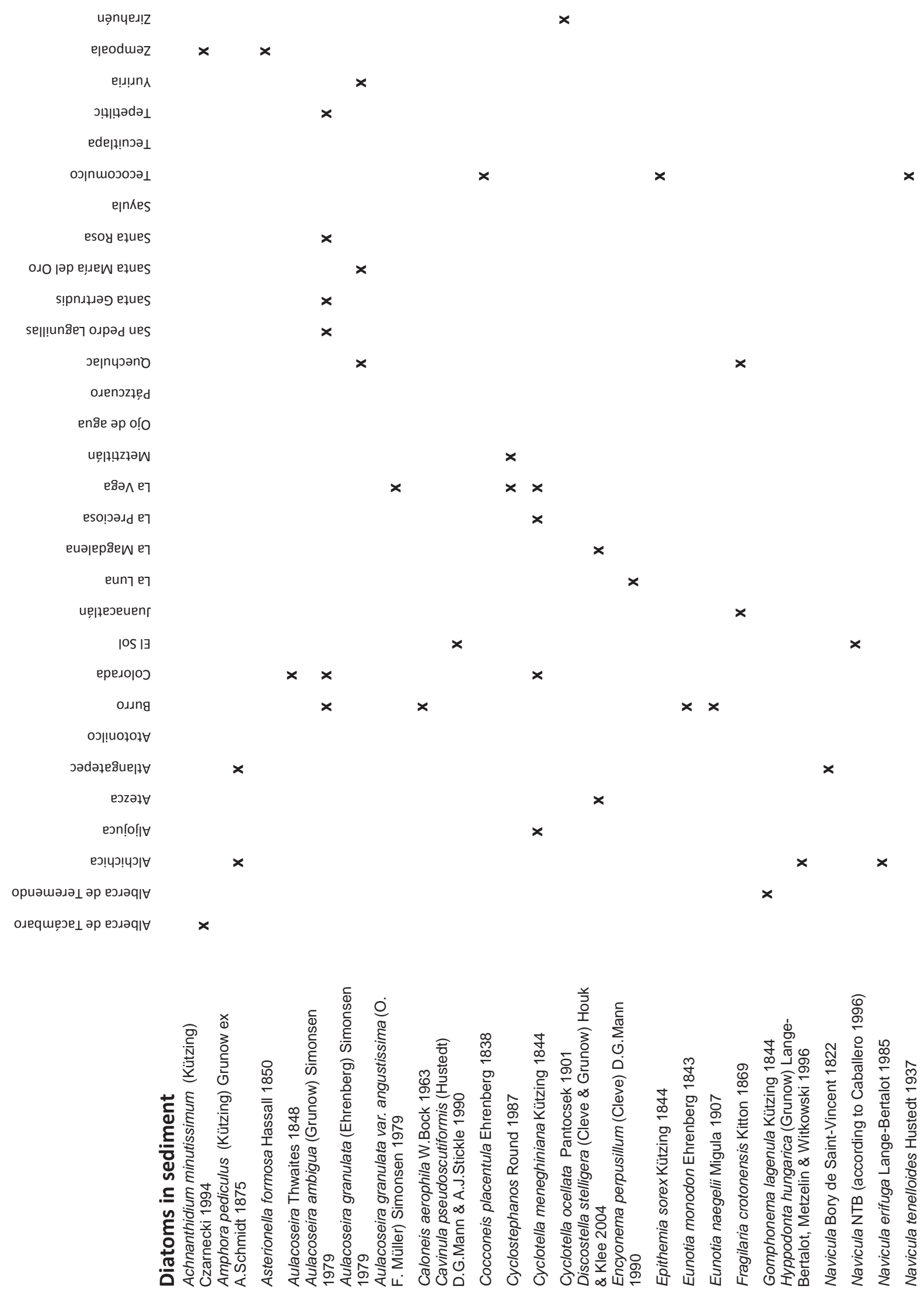




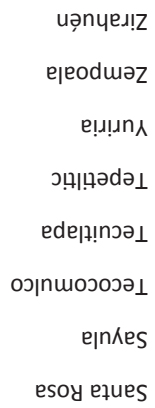

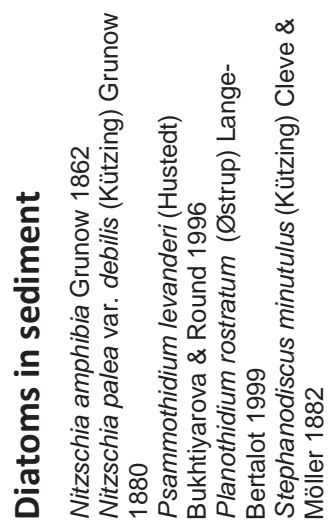




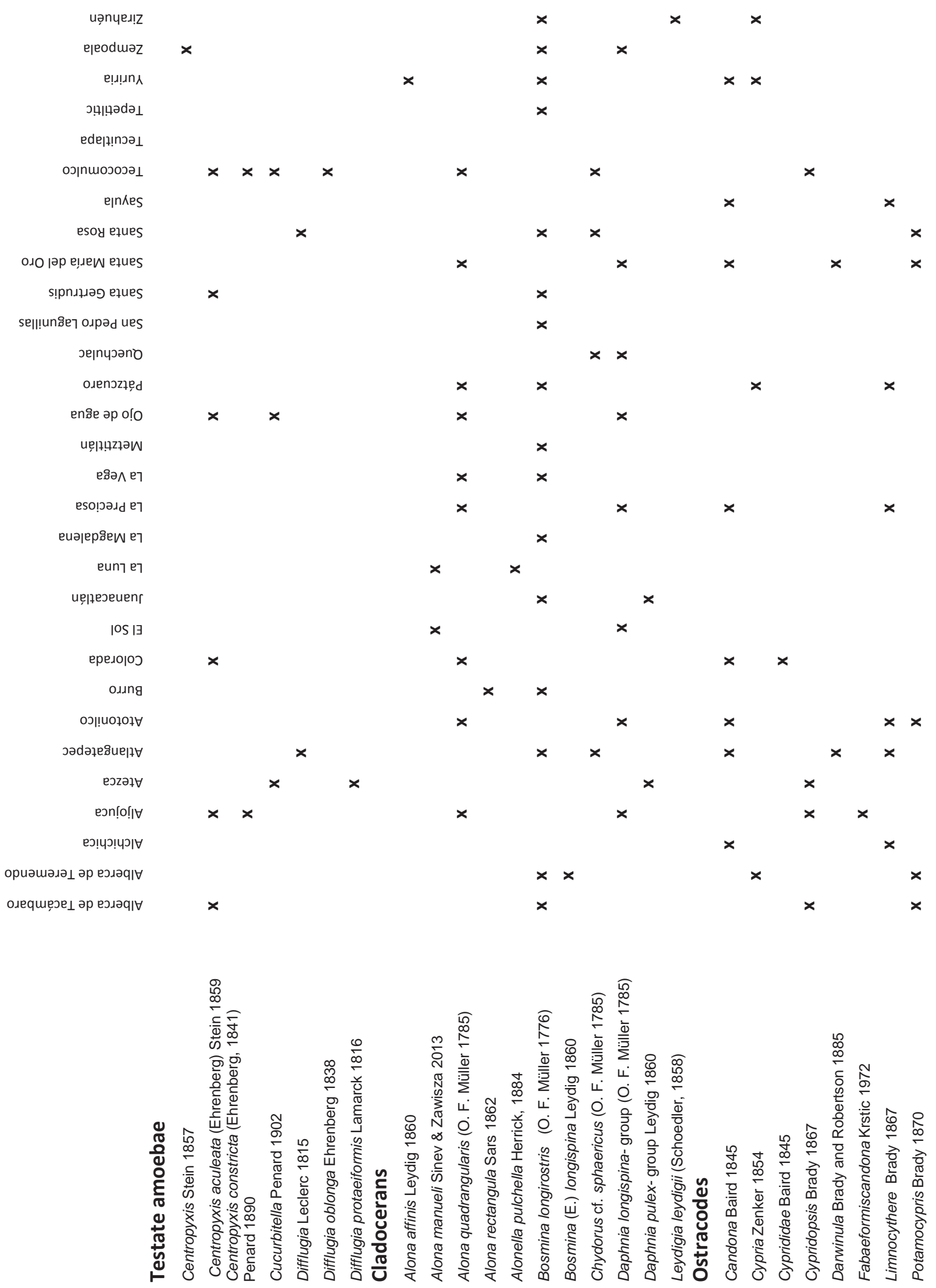

